\title{
Evaluation of Technical and Utility Programmatic Challenges With Residential Forced-Air Integrated Space/Water Heat Systems
}

Tim Kingston, Hillary Vadnal, Shawn Scott, and Dave Kalensky

Partnership for Advanced Residential Retrofit 


\section{NOTICE}

This report was prepared as an account of work sponsored by an agency of the United States government. Neither the United States government nor any agency thereof, nor any of their employees, subcontractors, or affiliated partners makes any warranty, express or implied, or assumes any legal liability or responsibility for the accuracy, completeness, or usefulness of any information, apparatus, product, or process disclosed, or represents that its use would not infringe privately owned rights. Reference herein to any specific commercial product, process, or service by trade name, trademark, manufacturer, or otherwise does not necessarily constitute or imply its endorsement, recommendation, or favoring by the United States government or any agency thereof. The views and opinions of authors expressed herein do not necessarily state or reflect those of the United States government or any agency thereof.

This report is available at no cost from the National Renewable Energy Laboratory (NREL) at www.nrel.gov/publications.

Available electronically at SciTech Connect http:/www.osti.gov/scitech

Available for a processing fee to U.S. Department of Energy and its contractors, in paper, from:

U.S. Department of Energy

Office of Scientific and Technical Information

P.O. Box 62

Oak Ridge, TN 37831-0062

OSTI http://www.osti.gov

Phone: 865.576.8401

Fax: 865.576.5728

Email: reports@osti.gov

Available for sale to the public, in paper, from:

U.S. Department of Commerce

National Technical Information Service

5301 Shawnee Road

Alexandria, VA 22312

NTIS http://www.ntis.gov

Phone: 800.553 .6847 or 703.605 .6000

Fax: 703.605.6900

Email: orders@ntis.gov 


\title{
Evaluation of Technical and Utility Programmatic Challenges With Residential Forced-Air Integrated Space/Water Heat Systems
}

\author{
Prepared for: \\ The National Renewable Energy Laboratory \\ On behalf of the U.S. Department of Energy's Building America Program \\ Office of Energy Efficiency and Renewable Energy \\ 15013 Denver West Parkway \\ Golden, CO 80401 \\ NREL Contract No. DE-AC36-08GO28308 \\ Prepared by: \\ Tim Kingston, Hillary Vadnal, Shawn Scott, and Dave Kalensky \\ Partnership for Advanced Residential Retrofit \\ Gas Technology Institute \\ 1700 S. Mount Prospect Road \\ Des Plaines, IL 60018 \\ NREL Technical Monitor: Stacey Rothgeb \\ Prepared under Subcontract No. KNDJ-0-40346-04
}

December 2016 
The work presented in this report does not represent performance of any product relative to regulated minimum efficiency requirements.

The laboratory and/or field sites used for this work are not certified rating test facilities. The conditions and methods under which products were characterized for this work differ from standard rating conditions, as described.

Because the methods and conditions differ, the reported results are not comparable to rated product performance and should only be used to estimate performance under the measured conditions. 


\section{Contents}

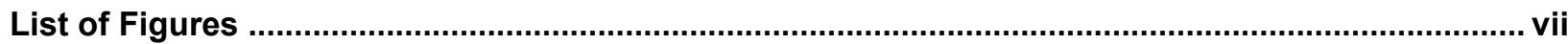

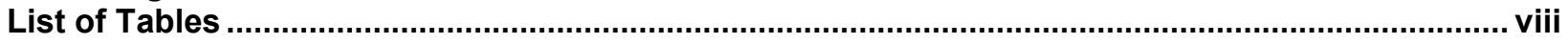

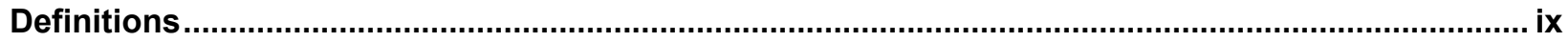

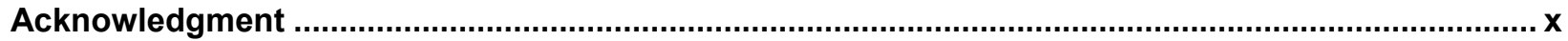

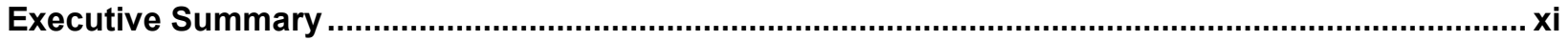

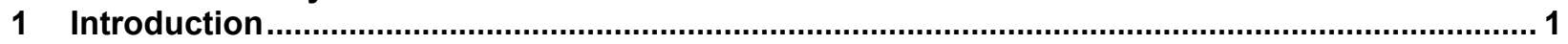

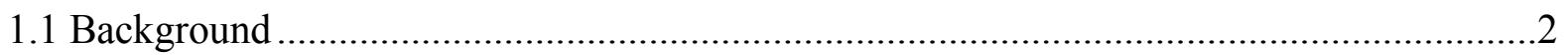

1.1.1 Objectives and Goals .....................................................................................

1.1.2 Prior Laboratory Testing of Combined Space and Water Heating Systems............ 3

1.1.3 GTI Field Testing of Combined Space and Water Heating Systems.....................4

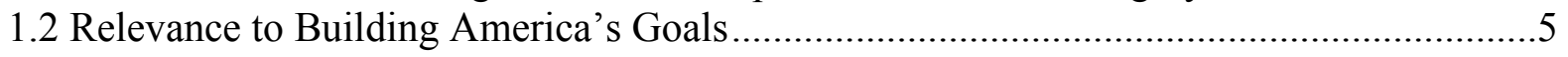

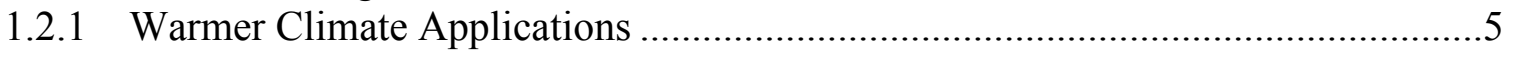

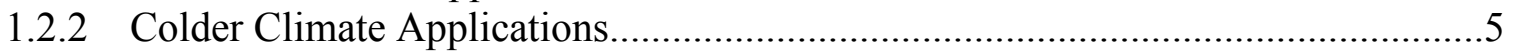

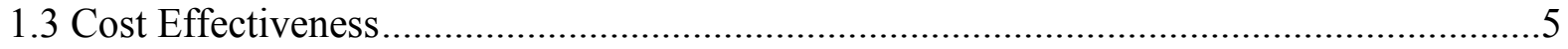

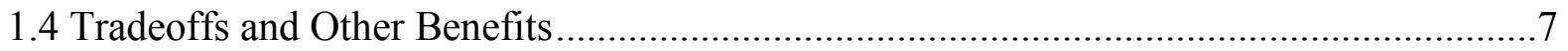

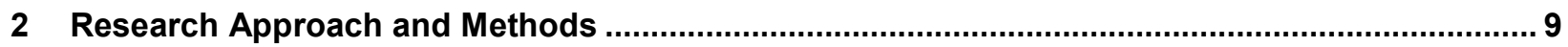

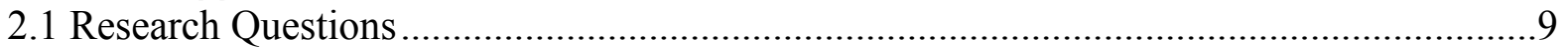

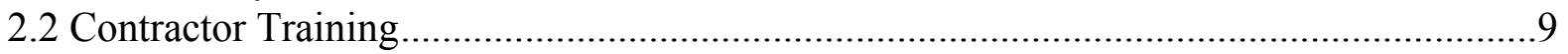

2.2.1 Code Misperception and a Barrier Broken Down..............................................9

2.3 Measurements and Instrumentation for Monitored Sites ........................................... 10

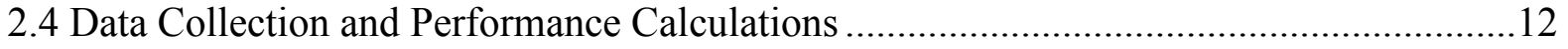

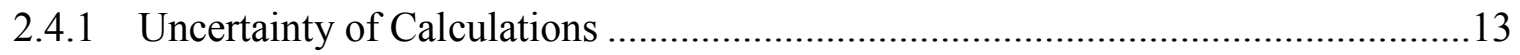

2.5 Energy Savings Calculation Methodology ............................................................... 15

2.5.1 Utility Billing and Heating Degree Day Savings Calculations.............................16

2.5.2 Pre-Retrofit Nameplate Efficiency Savings Calculations ..................................17

2.6 Host Site Combi System Configurations .............................................................. 17

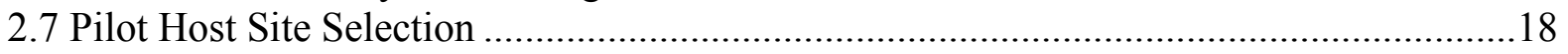

2.7.1 Nicor Host Site Summaries.......................................................................... 18

2.7.2 NYSERDA Host Site Summaries .................................................................. 18

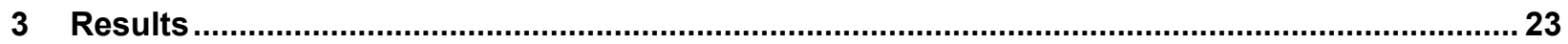

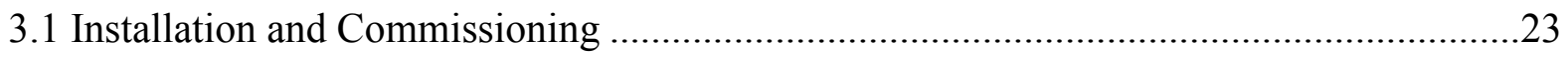

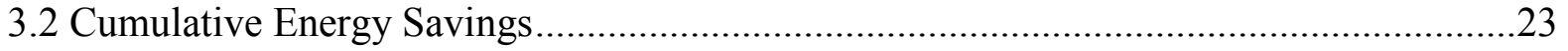

3.3 Energy Savings From Predetermined Baselines ............................................................24

3.4 Measured Efficiencies.......................................................................................2

3.4.1 Nicor Site 1 Performance Summary ..............................................................29

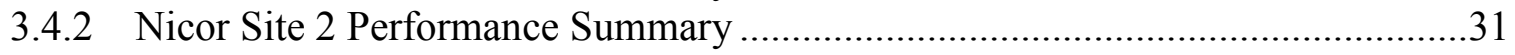

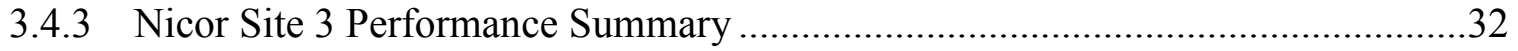

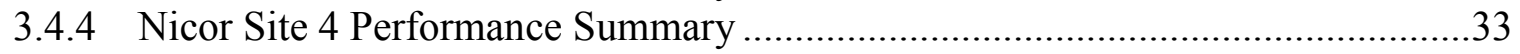

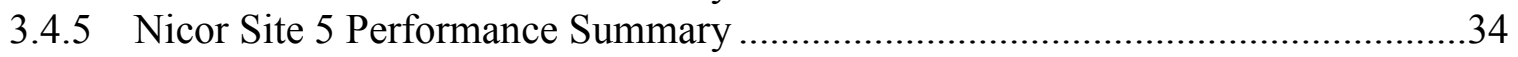

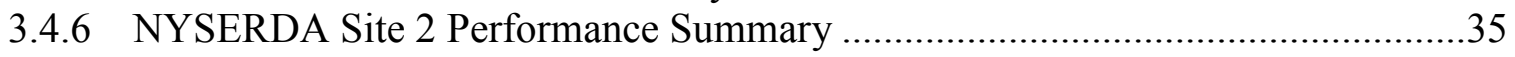

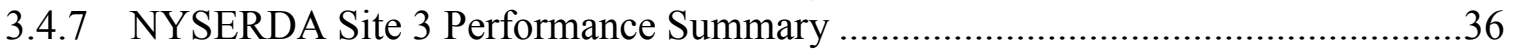

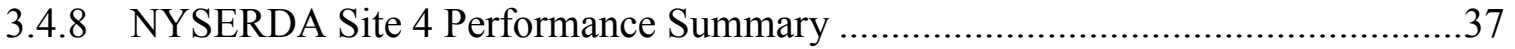

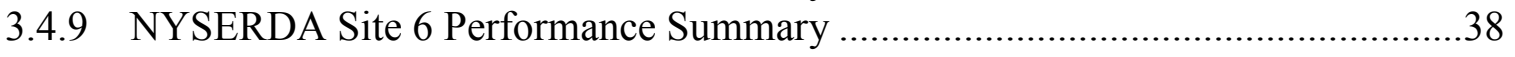

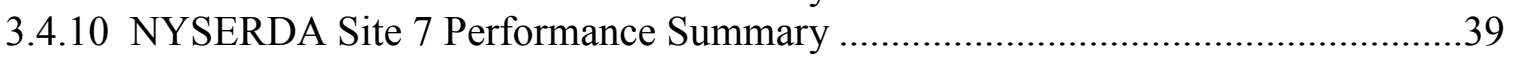

3.4.11 NYSERDA Site 8 Performance Summary ..................................................... 40

3.4.12 NYSERDA Site 9 Performance Summary .................................................... 41 
3.4.13 NYSERDA Site 10 Performance Summary ...................................................42

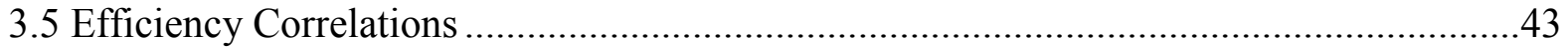

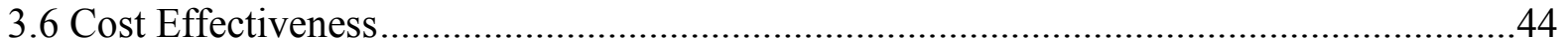

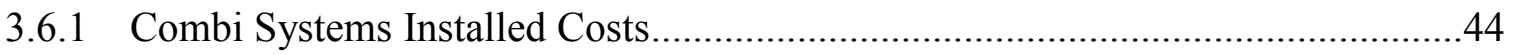

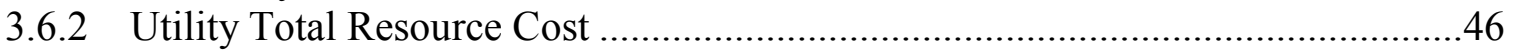

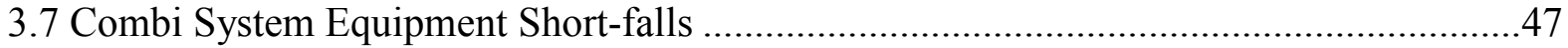

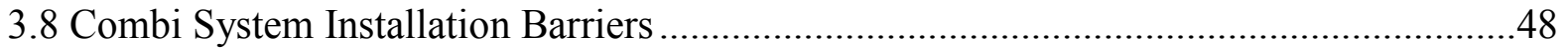

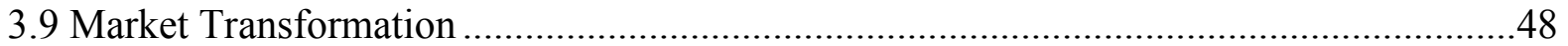

3.10 Programmatic Efficiency Measurement and Verification ..................................49

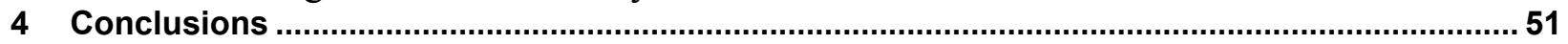

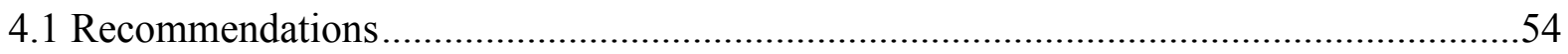

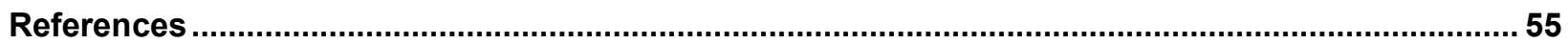




\section{List of Figures}

Figure 1. Combined system schematic furnished by Rheem.......................................................... 2

Figure 2. Relative costs of six combi system equipment configurations .......................................... 6

Figure 3. Piping diagram for combi systems with condensing tankless technology....................... 11

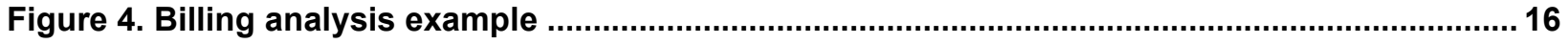

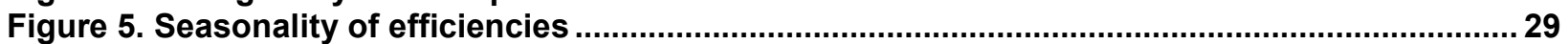

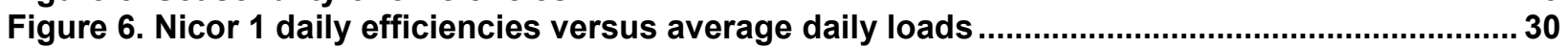

Figure 7. Nicor 1 daily efficiencies versus average AHU return water temperatures ....................... 30

Figure 8. Nicor 2 daily efficiencies versus average daily loads ....................................................... 32

Figure 9. Nicor 2 daily efficiencies versus average AHU return water temperatures ........................32

Figure 10. Nicor 3 daily efficiencies versus average daily loads ................................................... 33

Figure 11. Nicor 3 daily efficiencies versus average AHU return water temperatures ......................33

Figure 12. Nicor 4 daily efficiencies versus average daily loads .................................................. 34

Figure 13. Nicor 4 daily efficiencies versus average AHU return water temperatures .......................34

Figure 14. Nicor 5 daily efficiencies versus average daily loads .................................................. 35

Figure 15. Nicor 5 daily efficiencies versus average AHU return water temperatures ...................... 35

Figure 16. NYSERDA 2 daily efficiencies versus average daily loads ............................................ 36

Figure 17. NYSERDA 2 daily efficiencies versus average AHU return water temperatures ............. 36

Figure 18. NYSERDA 3 daily efficiencies versus average daily loads ............................................ 37

Figure 19. NYSERDA 3 daily efficiencies versus average AHU return water temperatures ............. 37

Figure 20. NYSERDA 4 daily efficiencies versus average daily loads .......................................... 38

Figure 21. NYSERDA 4 daily efficiencies versus average AHU return water temperatures .............. 38

Figure 22. NYSERDA 6 daily efficiencies versus average daily loads ............................................ 39

Figure 23. NYSERDA 6 daily efficiencies versus average AHU return water temperatures ............. 39

Figure 24. NYSERDA 7 daily efficiencies versus average daily loads .............................................. 40

Figure 25. NYSERDA 7 daily efficiencies versus average AHU return water temperatures ............. 40

Figure 26. NYSERDA 8 daily efficiencies versus average daily loads ............................................ 41

Figure 27. NYSERDA 8 daily efficiencies versus average AHU return water temperatures ............. 41

Figure 28. NYSERDA 9 daily efficiencies versus average daily loads ..............................................42

Figure 29. NYSERDA 9 daily efficiencies versus average AHU return water temperatures ............. 42

Figure 30. NYSERDA 10 daily efficiencies versus average daily loads .........................................43

Figure 31. NYSERDA 10 daily efficiencies versus average AHU return water temperatures ........... 43

Figure 32. Monthly efficiencies for packaged versus third-party AHUs ............................................ 44

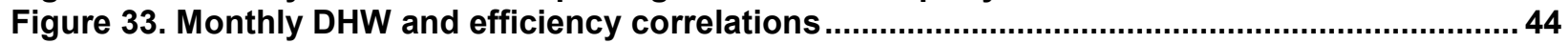

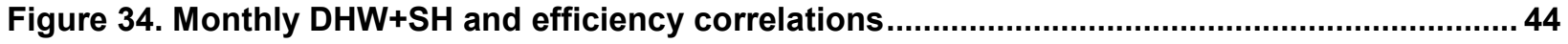

Figure 35. Laboratory test methodology for programmatic M\&V ....................................................5 50

Unless otherwise indicated, all figures were created by PARR. 


\section{List of Tables}

Table 1. Sensors List for Combi Systems With Condensing Tankless Technology.........................11

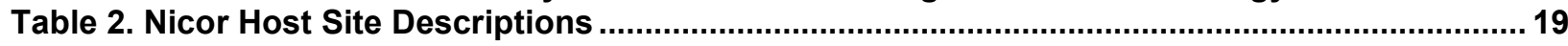

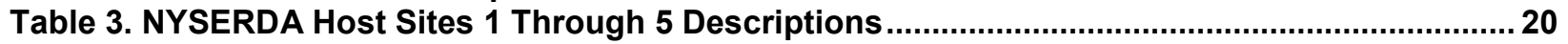

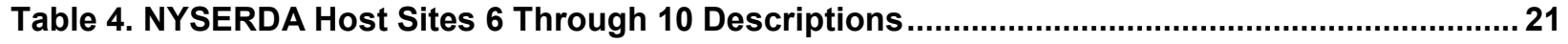

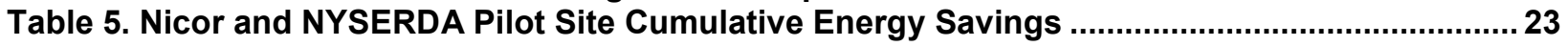

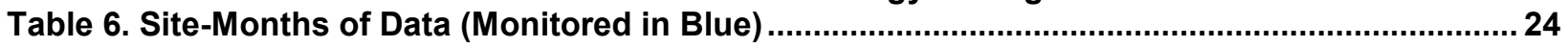

Table 7. Annualized Pilot Site Energy Usage and Therms Savings ............................................... 26

Table 8. Nicor Combi System Monthly Performance Data................................................................ 27

Table 9. NYSERDA Combi System Monthly Performance Data ..................................................... 28

Table 10. Nicor Site 1 Average Daily Loads Versus Performance by Month ..................................... 30

Table 11. Nicor Site 2 Average Daily Loads Versus Performance by Month .................................... 31

Table 12. Nicor Site 3 Average Daily Loads Versus Performance by Month .................................... 32

Table 13. Nicor Site 4 Average Daily Loads Versus Performance by Month .................................... 33

Table 14. Nicor Site 5 Average Daily Loads Versus Performance by Month .................................... 34

Table 15. NYSERDA Site 2 Average Daily Loads Versus Performance by Month.............................35

Table 16. NYSERDA Site 3 Average Daily Loads Versus Performance by Month............................... 36

Table 17. NYSERDA Site 4 Average Daily Loads Versus Performance by Month............................. 38

Table 18. NYSERDA Site 6 Average Daily Loads Versus Performance by Month............................. 39

Table 19. NYSERDA Site 7 Average Daily Loads Versus Performance by Month.............................. 40

Table 20. NYSERDA Site 8 Average Daily Loads Versus Performance by Month............................ 41

Table 21. NYSERDA Site 9 Average Daily Loads Versus Performance by Month.............................. 42

Table 22. NYSERDA Site 10 Average Daily Loads Versus Performance by Month........................... 43

Table 23. Forced-Air Combi Installed Cost Data From SoCal Pilot ............................................... 45

Table 24. Installed Costs for Separate High Efficiency Space and Water Heating Appliances ........ 46

Unless otherwise indicated, all tables were created by PARR. 


\section{Definitions}

AFUE

AHU

BA

Combi

DAQ

DHW

DOE

EE

EEP

EER

EF

ETP

GTI

HDD

HVAC

$\mathrm{M} \& \mathrm{~V}$

Nicor

NYSERDA

PARR

$\mathrm{SH}$

SoCal

TRC

UIL
Annual Fuel Utilization Efficiency

Air Handling Unit

Building America

Combined water and space heating systems

Data Acquisition System

Domestic Hot Water

U.S. Department of Energy

Energy Efficiency

Energy Efficiency Program

Energy Efficiency Ratio

Energy Factor

Emerging Technologies Program

Gas Technology Institute

Heating Degree Day

Heating, Ventilating, and Air Conditioning

Measurement and Verification

Nicor Gas Company

New York State Energy Research and Development Authority

Partnership for Advanced Residential Retrofit

Space Heating

Southern California Gas Company

Total Resource Calculation

United Illumination Company 


\section{Acknowledgment}

The authors acknowledge the participation of Nicor and the New York State Energy Research and Development Authority (NYSERDA) in providing access to, and support for the evaluation and host site implementation of combination space and tankless DHW heating system demonstrations and pilots. 


\section{Executive Summary}

Combined water and space heating ( $\mathrm{SH}$ ) systems, referred to herein as combis, use a single gasfired process or thermal engine to provide domestic hot water (DHW) and SH for a building. The combination of a hydronic air handling unit (AHU) and tankless water heater in applications suitable for combis can potentially improve the energy efficiency (EE) of meeting these combined heating needs in residential applications.

Although combi systems have been applied in residential buildings for two decades or more, the technology is underutilized. However, new housing construction practices and present-day retrofit measures are leading to more thermally efficient building envelopes and the decline of average home SH loads. This makes combi systems more applicable, especially as tankless water heater manufacturers have begun offering systems sold as single packages to meet both loads with onboard integrated DHW and SH controls.

This multiunit demonstration project was conducted to help document installation, performance, and cost effectiveness issues that needed to be addressed through research. The project put commercially available packaged combi systems as well as separate commercially available tankless water heaters and hydronic AHUs into the field through local contractors. The local contractors were trained by the participating manufacturers and Gas Technology Institute (GTI) staff under the auspices of utility-implemented Emerging Technology Programs (ETP).

Through GTI's U.S. Department of Energy (DOE) Building America (BA) team, Partnership for Advanced Residential Retrofit (PARR), the limited five-system Nicor Gas (Nicor) pilot in northern Illinois had its reported results supplemented by a 10 -system demonstration in New York State with NYSERDA. Moreover, the project provided the foundation for two additional utilities to launch combi pilots; one with Southern California Gas Company, and the other with United Illuminating Company. Those pilots are underway with an additional 30 of 36 planned combi units installed. While performance monitoring data were not available for those additional units, other tangible information collected from the sites contributed to some of the conclusions in this report.

The following summarizes conclusions that were drawn from the results of 13 monitored forcedair tankless water heater combi system demonstrations and pilots in the cold climates of Chicago and New York:

- Natural gas savings averaged across the 13 sites is estimated to be in the range of 5-13\%. Gas savings was estimated using monitored post-retrofit performance and pre-retrofit nameplate efficiency values.

- Measured in-situ combi system efficiencies were from near $80 \%$ to about $93 \%$ in the Nicor and NYSERDA data. Of the 13 monitored systems, there were 10 combi systems that were sold as integrated water heater and AHU packages. Nine of the integrated combi systems had measured in-situ system efficiencies near $80 \%$ to about $88 \%$ and one integrated combi system had a measured in-situ system efficiency of about $90 \%$. The remaining three combi systems were pieced together with separate water heaters and 
AHUs that were specifically designed for condensing combi system operation. Those three combi systems had measured in-situ system efficiencies of about $92 \%-93 \%$.

Note that combi system efficiencies were calculated by dividing total energy delivered for DHW and SH by total gas and electric energy consumed by the water heater (not including the air handling unit electricity)..

- Most currently available hydronic AHUs are not designed for combi systems with a condensing heating plant (Schoenbauer 2012). The combis that were sold as integrated water heater and AHU packages for this study were not designed to maximize temperature drops across the hydronic coils while maintaining sufficient supply airflows and temperatures. Therefore, water temperatures returning from the AHU to the water heater were not low enough to induce condensing water heater operation. One manufacturer of integrated combis has since discontinued sales of AHUs and has aligned product with a third-party AHU manufacturer. Another manufacturer of integrated combis has committed to a next-generation combi package that addresses shortfalls such as inconsistent condensing operation. Some third-party AHU manufacturers, including those participating in the NYSERDA study, have focused attention on combi system performance. Their AHUs are designed with water-to-air heat exchangers that transfer heat from the hot water to the room air more effectively, thereby maximizing coiltemperature drops while maintaining comfortable supply air. Forced-air combi system performance would benefit from the use of such "advanced" AHU designs.

- Like other SH systems including boilers and furnaces, combi system efficiencies may be negatively impacted by low SH load scenarios such as warm-climate applications and heating during shoulder months in cold climates. Cycling losses associate with turndown and the fact that standby losses become a higher fraction of the total load, factor into overall efficiencies. To satisfy market demand for unlimited DHW, contractors may choose the highest capacity tankless water heater available. However, despite manufacturer-claimed turndowns of up to 10:1 (in terms of burner capacity), results from this study indicate compromised performance $(10+$ percentage points) during some low $\mathrm{SH}$ load scenarios. Combi system performance would benefit from right-sized systems and control strategies that account for low SH loads relative to burner capacities.

- Combi systems installed in all of the monitored homes for this study met the SH loads. Host sites were from about 1,500 $\mathrm{ft}^{2}$ to larger than 3,000 $\mathrm{ft}^{2}$ and built between 1920 and 2013. In at least one case, the combi system was used in a zoned configuration with another heating system. Estimated SH load calculations for all of the host sites were less than $65 \mathrm{kBtu} / \mathrm{h}$. However, in some cases the water heater set point had to be increased up to $160^{\circ} \mathrm{F}$ to deliver comfortable supply air.

- The NorthernSTAR BA team set the maximum threshold for achieving condensing operation in combi systems at $105^{\circ} \mathrm{F}$ AHU return water (Schoenbauer 2012). Data from the monitored combi systems indicate strong correlations between reduced AHU return water and increased combi system efficiencies. In several cases, higher combi system efficiencies (near 90\% and higher) were seen with return water temperatures colder than $105^{\circ} \mathrm{F}$ than combi system efficiencies seen with return water temperatures hotter than $105^{\circ} \mathrm{F}$. However, there were exceptions where $90 \%+$ condensing combi system efficiencies were achieved with return water hotter than $105^{\circ} \mathrm{F}$ and up to $125^{\circ} \mathrm{F}$. 
Conversely, some data indicate combi system efficiencies in the low $80 \mathrm{~s}^{\circ} \mathrm{F}$ with $\mathrm{AHU}$ return water consistently colder than $105^{\circ} \mathrm{F}$. More research is needed to better understand the factors that affect condensing operation, such as heat exchanger and combustion design and control strategies.

- Combi systems installed in all of the monitored homes for this study met the DHW loads. However, some homeowners reported cold water slugs between hot water flows. This is known as the cold water sandwich effect and is a fairly common complaint with tankless water heater operation. The cold water sandwich effect is not attributed to added $\mathrm{SH}$ loads.

- Demonstration and pilot projects are often conducted in existing homes to provide baselines for performance and savings comparisons. However, combination systems may make the most sense in new construction since proper design of the total system is possible, including properly sized and insulated plumbing to avoid extended delay time in delivering water, and properly sized and sealed air ducts (Rudd 2012). In retrofit cases, the existing gas service line (either the outside utility line or in building) may not have adequate capacity to serve the high demand of a tankless water heater or high capacity storage type water heater. In addition, retrofit venting may be more difficult, and old scaled pipes may worsen water flow or inlet filter clogging problems (Rudd 2012).

- Demonstration and pilot data are extremely valuable for providing as-installed performance data, user satisfaction, and installing-contractor behavior. However, as the data from this project show, it is difficult to make direct system comparisons because of the many host site variables. More research is needed to determine how well heating systems such as traditional furnace/water heater, combis, and heat pumps compare in similar as-installed scenarios, but under controlled conditions.

- Field tests for this study exposed installation deficiencies due to contractor unfamiliarity with the products and the complexity of field engineering and system tweaking to achieve high efficiencies. Widespread contractor education must be a key component to market expansion of combi systems.

- Average installed cost for forced-air combi systems was determined to be about \$5,750. That cost would need to come down by about $15 \%-25 \%$ to make combis marginally acceptable in terms of utility total resource cost (TRC) for the applications evaluated. TRC is a methodology used by utilities to weigh benefits of an EE measure against the total cost to the utility to implement the measure. Indication that installed costs for combis are very close to the threshold for passing utility TRC tests is another reason for educating contractors and generating greater contractor familiarity with combis in order to drive installation costs down and initiate market transformation.

- One way to accomplish extensive training would be at the program level through utility EEP implementation contractors. The implementation contractors are responsible for executing individual EE measures, and as part of their work they link end users to installing contractors. Bulk training via "combi system workshops" could be accommodated as part of EE measure implementation.

- Nicor and other gas utilities are looking for ways to improve the benefits of high efficiency stand-alone water heating measures in their EEPs. By raising DHW heating 
and SH efficiencies with one EE measure, the benefits could be improved enough to outweigh the cost to the utility to implement a combi system measure. 


\section{Introduction}

Combined space and water heating (combi) systems use a gas-fired process or single thermal engine to provide domestic hot water (DWH) and space heating $(\mathrm{SH})$ for a building. The combination of a hydronic air handling unit (AHU) and tankless water heater in applications suitable for combis can potentially improve the energy efficiency (EE) of meeting these combined heating needs in residential applications. Powered by on-demand condensing technology at $90 \%+$ efficiency, combis consist of:

- A tankless or boiler on-demand water heater. The water heater serves two purposes in the hydronic system: first, it provides continuous DHW for use throughout the home. Second, when there is a call for $\mathrm{SH}$, the water heater provides hot water as the heatsource for a hydronic AHU. The tankless unit can be condensing or non-condensing. This research focused on high-efficiency, condensing tankless water heaters in support of the U.S. Department of Energy's (DOE) Building America (BA) energy savings goals.

- A hydronic AHU. The hydronic AHU houses a heating coil in place of either electric heating elements or gas-fired heat exchangers. When in heating mode, a water pump circulates hot water between the water heater and the heating coil to meet the SH load.

- A cooling coil. Though not required, combi systems for year-round space conditioning include a refrigerant evaporator coil. In cooling mode, the refrigerant is circulated through the evaporator coil the same as in a conventional direct-expansion cooling system.

Combis can be purchase as pre-engineered packaged systems or can be custom built by bringing together AHUs and water heaters built by separate third-party manufacturers. Storage water heaters have historically been used in combi systems, but an influx of foreign-made tankless (ondemand) water heater technologies that are compact, high capacity, and wall-hung have entered the market. Because storage water heaters store hot water, they perform well by quickly delivering water at set point for short demands. However, they deliver varying water temperatures during long draws, because of temperature stratification in the tank. Those varying water temperatures lead to SH supply air temperature variations of up to $6^{\circ} \mathrm{F}$ (Kingston and Scott 2013). On-demand technology performs well with long draws at steady flow rates. Forced-air combis often employ an on-demand tankless water heater sized to meet DHW and SH loads. They are equipped with flow sensors that give priority to DHW by temporarily shutting the hydronic AHU down.

Figure 1 shows a typical forced-air combi configuration. Heated water from the water heater passes through a water-to-air heat exchanger in the AHU to heat supply air. A fan circulates the heated air through the heat exchanger and into the building's air distribution network to meet the SH load. If a demand for DHW occurs while there is a call for SH, the system shuts the AHU off until the DHW demand is satisfied. Combis have several advantages over traditional separate appliances, including: 
- Easy integration into buildings with forced-air furnaces and storage water heaters

- Reduced potential for durability concerns experienced with high efficiency furnaces (non-integrated systems) associated with cool return air

- Better capacity modulation and comfort control compared with gas furnaces or electric heat pumps

- Safer operation than natural draft appliances because they use one common sealed combustion vent

- Require only a single combustion air and vent pipe, replacing two pipes otherwise needed for separate heating and water heating appliances

- Better supply air control compared with gas furnaces or electric heat pumps because water flow rate, water temperature, and air flow rate can be independently controlled.

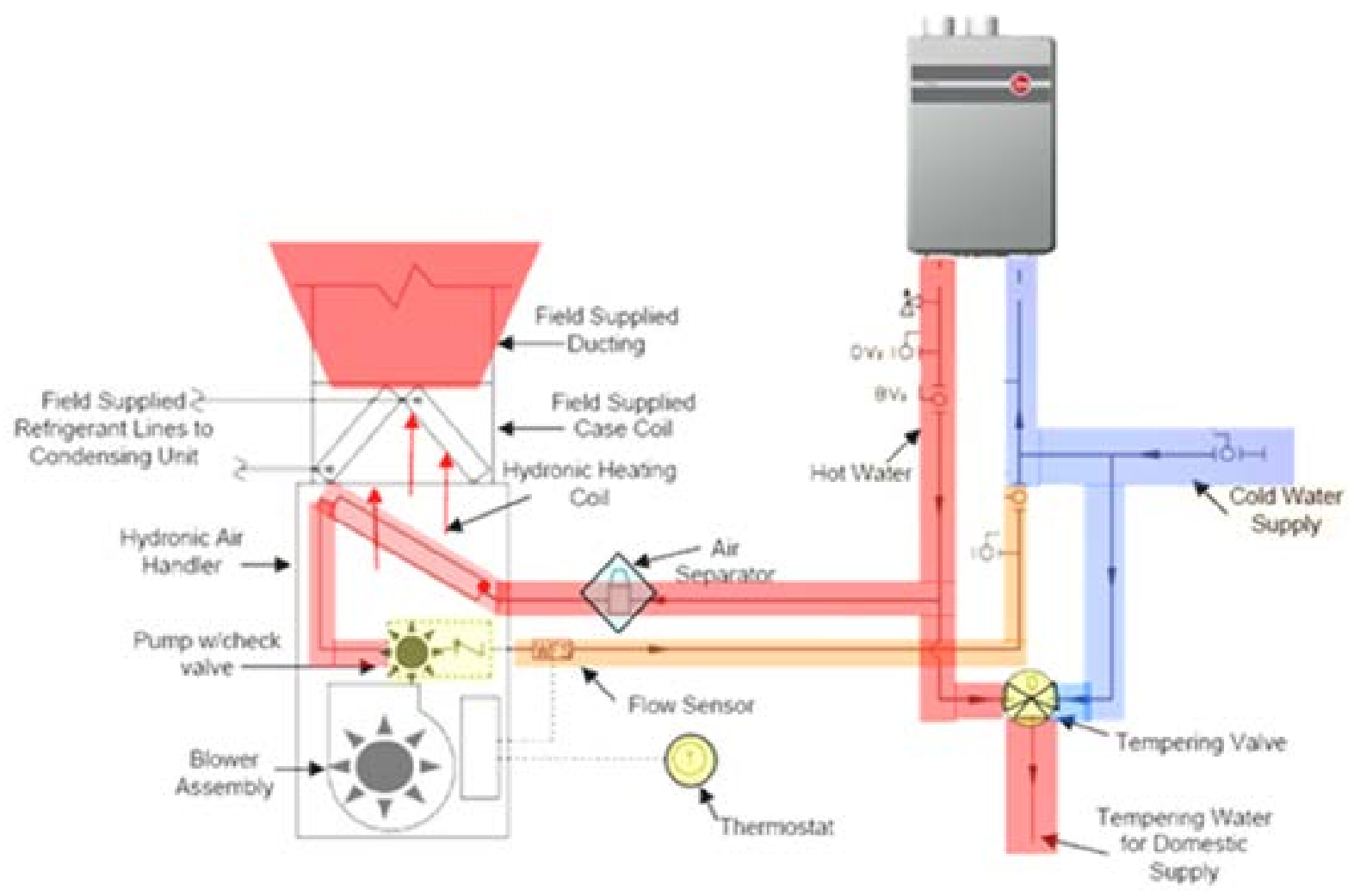

Figure 1. Combined system schematic furnished by Rheem

\subsection{Background}

Although combi systems have been applied in residential buildings for two decades or more, the technology is underutilized and its market share barely exceeds $2 \%$. However, new housing construction practices and present-day retrofit measures are leading to more thermally efficient building envelopes and the decline of average home SH loads. This makes combi systems more applicable, especially as tankless water heater manufacturers have begun offering high capacity systems to meet both loads with onboard integrated DHW and SH controls. 
Multiple major manufacturers are entering or expanding in the marketplace with competitively priced, integrated, pre-engineered systems with advanced controls for enhanced operability and national product support and training. New systems offer improved reliability and cost effectiveness while reducing system design and installation errors, a historic challenge for this and other emerging technologies.

Combis offer operational benefits over conventional high efficiency furnaces and water heaters under certain conditions. Investing in one piece of high efficiency equipment, and realizing significant energy savings for two end use loads improves technology utilization and thus payback for consumers. For energy efficiency programs (EEPs), combis improve the economics of upgrading to a high efficiency water heater for DHW use, as the combined DHW and SH loads are accomplished with one EE program measure.

Together with utility partners that participate in Gas Technology Institute's (GTI) Emerging Technology Program (ETP), this multiunit field demonstration project was conducted to help document combi system installation, performance, and cost effectiveness issues that needed to be addressed through pilot activities in this project. The pilots characterize in-field space and water heating efficiency, potential energy savings, and load response capabilities of specific combi systems. The pilots also help identify installer best practices and commissioning techniques necessary for improved efficiency and performance. Furthermore, the pilots help evaluate the technical challenges as well as programmatic design issues associated with replacing a warm-air furnace and tank-type water heater with a combi system.

\subsubsection{Objectives and Goals}

The objective of this project was to put commercialized combi units into the field through local contractors who were trained by manufacturer and GTI staff under the auspices of utilityimplemented ETPs. Through GTI's DOE BA team, Partnership for Advanced Residential Retrofit (PARR), New York State Energy Research and Development Authority (NYSERDA), and other partners, the project documented system performance and installations. Specific goals for the project included:

- Program planning. The goal for this task was to detail field test procedures to effectively validate costs and benefits and to develop an incentive program strategy that would motivate customers to buy efficient combi products. The program strategy was the basis for subsequent program designs through GTI's ETP.

- Program implementation. The goal for this task was to put a large sample of units into the field through partner-utility ETPs. This required establishing manufacturing and installation partners and conducting technical and sales training.

- Measurement and reporting. The goal for this task was to record and report system performance in terms of EE, reliability and comfort as well as installation issues that could present barriers to widespread adoption.

\subsubsection{Prior Laboratory Testing of Combined Space and Water Heating Systems} In 2012 the NorthernSTAR DOE BA team completed laboratory testing on a variety of complete combi systems and individual components before implementing a field installation study of its own (Schoenbauer 2012). Hydronic AHU steady-state performance measurements determined 
output capacities that provided acceptable return water and supply air temperatures. Heating plant capacity results were used to develop algorithms to determine whether a system could meet DHW and SH loads. Multiple systems were configured in the laboratory and experienced contractors reviewed initial designs to provide recommendations to improve performance, reliability, ease of installation, and cost. NorthernSTAR's work revealed that controlling return water temperatures by adjusting water and air flow rates was the key to achieving condensing $\mathrm{SH}$ performance with combi systems.

GTI used NorthernSTAR's key findings from their laboratory research project to train local installing contractors for the utility-implemented ETPs.

\subsubsection{GTI Field Testing of Combined Space and Water Heating Systems}

GTI combi field testing for PARR was conducted in collaboration with Nicor Gas (Nicor) in northern Illinois through its ETP. Nicor's ETP helps introduce new EE technologies by selecting and demonstrating promising new products and practices that have the potential to realize gas savings for Nicor customers. Project ideas are selected for pilot assessments that provide important information on real-world performance, operating energy savings and installation costs for future EE programs. The ETP focuses on technologies that are new to the market or have not yet achieved broad market acceptance. After pilot assessments are conducted, the technologies are evaluated to determine if they should be added to the Nicor EEP. Combi technology was selected for pilot assessments, and five monitored systems were installed in installing contractors homes or shops for evaluation.

In parallel with the Nicor combi pilot assessments, a similar demonstration was done with NYSERDA. For the NYSERDA pilot, 10 monitored combi systems were installed in homes across New York. The research for the two projects was mutually supportive and provided the foundation for two additional utilities to launch their own combi pilots; a 30-unit pilot with Southern California Gas Company (SoCal), and a six-unit pilot with United Illuminating Company (UIL).

The SoCal pilot is ongoing and includes the installation of 30 combis with five monitored sites. The pilot is being conducted through GTI's own North American ETP collaborative in conjunction with SoCal's ETP. Like Nicor, the combi technologies will be evaluated by SoCal to determine if they should be included as an EE measure in its EEP. A principal objective for the SoCal project is to deliver a pilot at scale in cooperation with other partners throughout the country (NYSERDA, Nicor, DOE BA) to foster meaningful market transformation. While it is important to collect data on performance relative to the baseline for the SoCal project, it is as important to develop the marketplace. Developing the marketplace includes understanding how a disruptive technology such as combis works for contractors, distributors, homeowners, and other stakeholders and in turn identifies and develops strategies to overcome key technical and market barriers. As such, a key outcome is building a foundation for SoCal's EEP that not only includes quantitative data such as performance, energy savings, and installed costs, but also establishes a core group of trained contractors, feedback from a large number of local homeowners, and insights for program implementation staff that could be used for program design, incentive structure, marketing, and trades cooperation. 
The ongoing UIL demonstration project includes the installation of six monitored combis. This project is a demonstration for the utility rather than a pilot to drive market transformation. UIL is seeking to better understand operational performance for specific combi configurations.

Depending on in-field performance, UIL might consider launching a pilot project to determine if combi technology could be included as an EE measure in its EEP.

\subsection{Relevance to Building America's Goals}

Combi systems have the potential to improve home energy performance through increasing DHW and SH efficiencies while eliminating combustion safety issues in airtight homes. Incremental efficiency improvements from an efficient combi system suggests substantial energy and cost savings. Although research indicates that those combi system efficiency gains may be less than implied above, specifically in SH, significant improvements can be achieved.

\subsubsection{Warmer Climate Applications}

The application of combi systems in warmer climates can capture positive energy savings benefits. In warmer climates, the temperature of hot water delivered to the AHU can be turned down from $140^{\circ}-160^{\circ} \mathrm{F}$ to about $120^{\circ} \mathrm{F}$. This lower temperature allows the system to achieve high condensing efficiencies, thereby saving energy and money for the homeowner.

However, warmer climates have smaller overall heat loads that often result in the system operating at less than full load. Operating at turndown loads could negatively impact the system's overall efficiency. This issue can be exacerbated in smaller homes with even lower than average heating loads. Currently, commercial systems can accommodate turndown rates of as low as 10:1 in some cases. Most commercially available condensing tankless systems tend to have large gas input rates (minimum of $150,000 \mathrm{Btu} / \mathrm{h}$ to a maximum of $199,000 \mathrm{Btu} / \mathrm{h}$ ). As larger systems, they are more likely to be run at a turned down rate in warmer climates, further restricting opportunities to achieve condensing high efficiencies. Although non-condensing tankless systems are available, they do not offer the EE benefits of condensing units.

Past research has noted that manufacturers should consider offering smaller systems that would be able to achieve full load, condensing efficiencies while meeting the more modest heating demands of warmer climates.

\subsubsection{Colder Climate Applications}

By contrast, the application of condensing tankless combi systems in colder climates can be beneficial since they will run at high loads. However, the temperature of the hot water delivered to the air handler is often set high $\left(140^{\circ}-160^{\circ} \mathrm{F}\right)$ in order to meet the large heating load. This high temperature setting makes it more challenging to achieve condensing efficiencies and contributes in practice to the lessening of the combi system efficiency gains noted above.

Manufacturers have indicated they are working to develop condensing tankless systems that can rely on lower temperature hot water to the AHU to boost their efficiency, while still ensuring the water is hot enough to meet health and safety standards for domestic use.

\subsection{Cost Effectiveness}

According to recent DOE BA research (Rudd 2012), there are a range of equipment costs for combi systems varying by the equipment included in the configurations. Figure 2 provides a 
general guideline of those costs. System costs are also strongly influenced by contractor familiarity with the system and installation best practices as well as whether the equipment is being placed in a new construction or a retrofit scenario. In retrofit scenarios, there can be additional costs associated with gas line upgrades to accommodate the high capacity burners and the direct venting of condensing tankless water heaters, ductwork modifications, and new plumbing runs between the water heater and AHU.

This study focuses on the lowest cost system in Figure 2 consisting of a condensing tankless water heater and hydronic SH AHU.

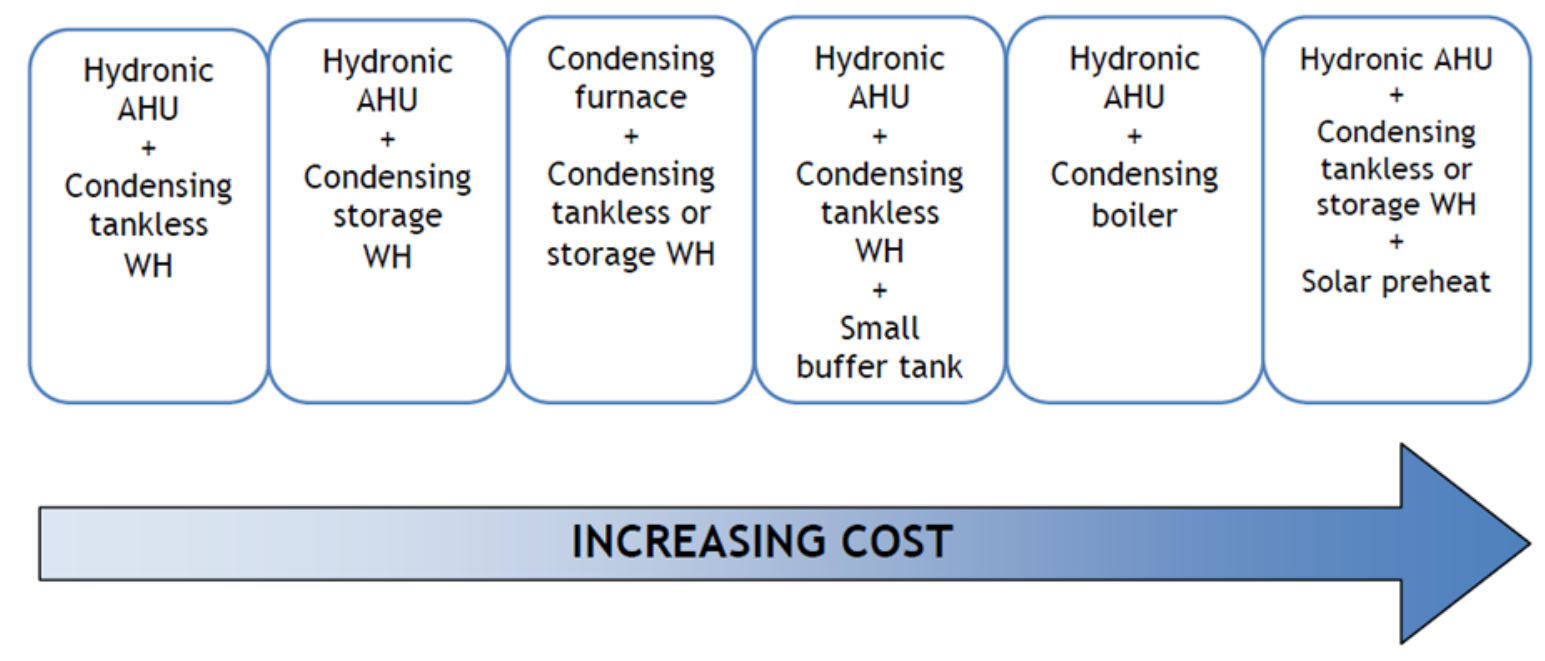

Figure 2. Relative costs of six combi system equipment configurations

There are limited data to make direct comparisons between installed costs for combis and combined installation costs for separate high efficiency condensing furnaces and high efficiency condensing water heaters. In California, where nearly 30 combis have been installed through a utility ETP pilot, the installed cost for combis averaged \$5,750. That included the costs for the water heater and AHU equipment and installation, but did not include HVAC upgrades such as refrigerant and air distribution infrastructure. In Chicago, where thousands of high efficiency furnaces (95\% AFUE) and mid-efficiency water heaters $(0.67 \mathrm{EF})$ have been installed through a utility EEP, the collective installed cost averaged $\$ 4,700$. These data sets provide some indication of incremental costs, but are not direct comparisons. For new construction, there are some indications that installed costs of combi systems can actually be lower than those of a similar efficiency separate furnace and water heater. Additionally, high volume installations can be expected to reduce costs as contractors become more familiar with combi technology. 


\subsection{Tradeoffs and Other Benefits}

Combined space and water heating systems can offer a wide variety of benefits:

- High efficiency and capacity. The packaged combi systems that are commercially available are roughly $95 \%$ efficient. The lack of a storage tank eliminates standby heating losses. The tankless water heater can also offer high heating capacity compared to conventional storage water heaters.

- Energy savings. Studies indicate integrated systems can reduce energy consumption by up to $20 \%$ compared to separate water heating and SH equipment (Kingston and Scott 2013). Combi systems can provide up to $10 \%$ whole-house energy savings on average across cold, mixed and warm climates, while maintaining homeowners comfort.

- Single piece of equipment. A principal benefit to homeowners is their investment in just one piece of high-efficiency equipment that serves two heating loads. The cost of this integrated system, including labor can be as low as $\$ 3,500$, but can be as high as $\$ 10,000$ depending on complexity and contractor familiarity (Schoenbauer et al. 2011). Contributing to additional costs are often-required gas line and venting upgrades.

- Space savings. Using a wall-hung tankless water heater and an AHU dimensionally similar to a furnace, can offer valuable floor space savings compared to a traditional storage water heater and furnace.

- Safety and venting. Condensing combi units incorporate direct venting systems that eliminate combustion safety issues that arise with tightly insulated homes using atmospheric or even power venting alternatives.

These systems do face barriers to wider adoption:

- Cost and availability. There is uncertainty among potential customers and installers in terms of equipment installed costs, installation and service contractor coordination, customer awareness of benefits, and natural gas service availability.

- Technical considerations. Combi systems require stable water temperature throughout the range of common flow rates and use patterns. Regular filter cleaning intervals are needed to avoid excessive mineral scale and galvanic corrosion. Consistency of water temperature at low flow rates can be an issue, depending on the minimum draw required to activate the burner (many tankless units have activation thresholds at $0.4 \mathrm{gpm}$, with some units able to accommodate even lower flow rates once activated). Most manufacturers implement a sensor to detect hot water draws. The sensor shuts the AHU down temporarily to give priority to DHW needs. Room temperature recovery could be significant, depending on the DHW demands, their durations, outside air temperatures, and thermostat cycles.

- Market barriers. A major barrier to wide acceptance of a new technology or practice is a customer's perceived risk that purported benefits will never be realized and a vendor's or installer's perceived risk that working in this business will be unprofitable.

- Rating procedures. Current rating procedures are designed to assess single end-use equipment, such as furnaces and water heaters. The procedures do not specifically 
address combi systems. However, ASHRAE has formed a Standard Project Committee (SPC 124) to develop combi testing and rating standards.

- Short draws. Compared to standard storage water heaters, the performance of tankless water heaters is negatively affected by multiple short-draws and associated thermal cycling losses on the system. The compact heat exchanger results in a large pressure drop and units have a minimum hot water draw rate to initiate burner firing. Furthermore, burner ignition delay can result in water wastage and the cold water sandwich effect during low or intermittent draws. 


\section{Research Approach and Methods}

\subsection{Research Questions}

The field demonstration work for this project addressed the following research questions:

1. What are expected energy savings for single-family detached homes?

2. What is SH efficiency for installed systems?

3. How can efficiencies be optimized through equipment selection, installation strategies, or site selection?

4. Are the expected installed costs and proven benefits sufficient to meet utility gas costeffectiveness requirements for utility rebates?

5. Do systems fall short of meeting space or water heating load; was occupant comfort or convenience impacted?

6. Are there any significant barriers to installing combined systems, house, or site attributes that should be avoided?

7. Does the detailed analysis of gas use data from instrumented demonstrations compare similarly to the gas billing data analysis approach (which would likely be used to verify energy savings under a full-scale program)?

8. How should the system be delivered to the market to best drive market adoption (e.g., to contractor, to end user)?

\subsection{Contractor Training}

Through this PARR program and other utility ETP projects, GTI and its manufacturing partners have conducted combi system training sessions for a dozen HVAC contractors in California, New York, and Illinois. All of the contractors were identified through GTI's utility partners, and most of them were utility trade allies working with the utilities and their implementation contractors to support their ETPs/EEPs.

Most of the contractors that participated in GTI's training sessions were heating, ventilation, and air conditioning (HVAC) contractors. While water heaters are typically installed by plumbing contractors, those contractors often lack HVAC expertise for installing combis. On the other hand, some HVAC contractors, particularly small shops, do not have licensed plumbers on staff to install the water and gas piping. The multitrade expertise required to install combis is an installation barrier that needs to be overcome through widespread training. One way to accomplish extensive training would be at the program level through utility EEP implementation contractors. The implementation contractors are responsible for executing individual EE measures and as part of their work they link end users to installing contractors. Bulk training via combi system workshops could be accommodated as part of EE measure implementation.

\subsubsection{Code Misperception and a Barrier Broken Down}

In early dialogue with one of the major water heater manufacturer's distribution channels in Nicor service territory, a perceived code barrier was identified. The perception was that combi systems were not being installed in homes because inspectors were prohibiting them. The problem stemmed from past installations in the region where resourceful contractors were field 
engineering makeshift combi systems with off-the-shelf components. While those systems may have served the purpose, two specific code violations were sited and then ingrained in the trade.

1. There must be provisions that prohibit potable water from standing in the heat transfer unit when not in use.

2. Each water heater must bear a statement on the rating plate indicating it is suitable for potable water heating and $\mathrm{SH}$.

The perceived barrier coupled with lack of knowledge regarding the manufacturer's tankless water heater and hydronic AHU operation prevented the manufacturer from initially implementing its equipment discount plan through a distributor; thus hindering release of the new technology within the trade. In reality, the manufacturer's combi package did address both code issues by employing automatic circulation of water in the furnace and by identifying on the National Sanitation Foundation certificate that the system was suitable for potable water heating and SH.

Through training, the code misperception was alleviated within the manufacturer's distribution channels in Nicor service territory. With that barrier broken down, the manufacturer was able to develop an equipment discount and contractor rebate program with its local distributor in Nicor's territory.

\subsection{Measurements and Instrumentation for Monitored Sites}

Figure 3 shows the installation diagram for forced-air combi systems with the locations of measurement sensors used for data collection for the Nicor and NYSERDA sites. There were eight temperature probes (all immersed), two in-line water flow meters, an in-line gas meter, and two electric Watt-hour meters installed at each of the monitored sites. Table 1 lists the sensors that were used. 


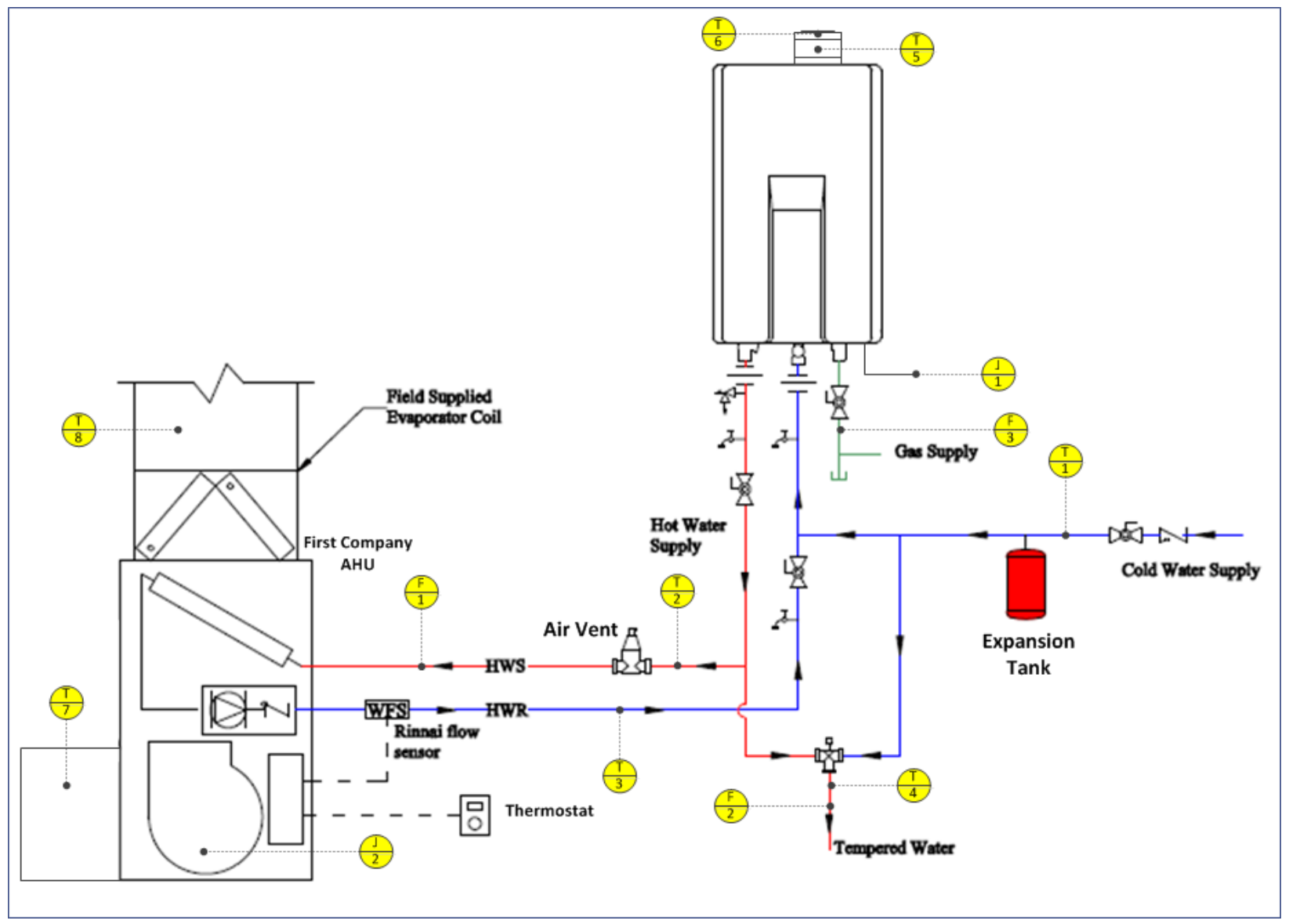

Figure 3. Piping diagram for combi systems with condensing tankless technology

Table 1. Sensors List for Combi Systems With Condensing Tankless Technology

\begin{tabular}{|c|c|c|c|c|c|}
\hline Sensor & Location & Purpose & Equipment & $\begin{array}{c}\text { Manufacturer/ } \\
\text { Model }\end{array}$ & Accuracy \\
\hline T1 & $\begin{array}{c}\text { Within } 3 \mathrm{ft} \text { of water } \\
\text { heater inlet }\end{array}$ & $\begin{array}{l}\text { Inlet } \mathrm{x} \\
\text { supply }\end{array}$ & Thermocouple & $\begin{array}{c}\text { Omega/ } \\
\text { TMQSS-125G-6 }\end{array}$ & $\begin{array}{c} \pm 1^{\circ} \mathrm{F} \text { or } \\
0.4 \%\end{array}$ \\
\hline $\mathbf{T 2}$ & $\begin{array}{c}\text { Within } 3 \mathrm{ft} \text { of AHU } \\
\text { water inlet }\end{array}$ & $\begin{array}{l}\text { Inlet hydronic } \\
\text { loop }\end{array}$ & Thermocouple & $\begin{array}{c}\text { Omega/ } \\
\text { TMQSS-125G-6 }\end{array}$ & $\begin{array}{c} \pm 1^{\mathrm{o}} \mathrm{F} \text { or } \\
0.4 \%\end{array}$ \\
\hline T3 & $\begin{array}{c}\text { Within } 3 \mathrm{ft} \text { of AHU } \\
\text { water outlet }\end{array}$ & $\begin{array}{c}\text { Outlet } \\
\text { hydronic loop }\end{array}$ & Thermocouple & $\begin{array}{c}\text { Omega/ } \\
\text { TMQSS-125G-6 }\end{array}$ & $\begin{array}{c} \pm 1^{\circ} \mathrm{F} \text { or } \\
0.4 \%\end{array}$ \\
\hline T4 & $\begin{array}{c}\text { After mixing valve } \\
\text { within } 3 \mathrm{ft} \text { of mixing } \\
\text { valve }\end{array}$ & DHW & Thermocouple & $\begin{array}{c}\text { Omega/ } \\
\text { TMQSS-125G-6 }\end{array}$ & $\begin{array}{c} \pm 1^{\circ} \mathrm{F} \text { or } \\
0.4 \%\end{array}$ \\
\hline T5 & $\begin{array}{l}\text { Within } 3 \mathrm{ft} \text { of water } \\
\text { heater on } \\
\text { combustion air inlet }\end{array}$ & $\begin{array}{l}\text { Tankless } \\
\text { heater intake } \\
\text { air }\end{array}$ & Thermocouple & $\begin{array}{c}\text { Omega/ } \\
\text { TMQSS-125G-6 }\end{array}$ & $\begin{array}{c} \pm 1^{\circ} \mathrm{F} \text { or } \\
0.4 \%\end{array}$ \\
\hline T6 & Within $3 \mathrm{ft}$ of water & Tankless & Thermocouple & Omega/ & $\pm 1^{\circ} \mathrm{F}$ or \\
\hline
\end{tabular}




\begin{tabular}{|c|c|c|c|c|c|}
\hline Sensor & Location & Purpose & Equipment & $\begin{array}{c}\text { Manufacturer/ } \\
\text { Model }\end{array}$ & Accuracy \\
\hline & $\begin{array}{c}\text { heater on exhaust } \\
\text { outlet }\end{array}$ & heater exhaust & & TMQSS-125G-6 & $0.4 \%$ \\
\hline $\mathbf{T 7}$ & $\begin{array}{c}\text { Within } 3 \mathrm{ft} \text { of } \mathrm{AHU} \\
\text { on return duct }\end{array}$ & $\begin{array}{l}\text { AHU return } \\
\text { air }\end{array}$ & Thermocouple & $\begin{array}{c}\text { Omega/ } \\
\text { TMQSS-125G-6 }\end{array}$ & $\begin{array}{c} \pm 1^{\circ} \mathrm{F} \text { or } \\
0.4 \%\end{array}$ \\
\hline T8 & $\begin{array}{c}\text { Within } 3 \mathrm{ft} \text { of AHU } \\
\text { on supply duct }\end{array}$ & $\begin{array}{l}\text { SHUsupply } \\
\text { air }\end{array}$ & Thermocouple & $\begin{array}{c}\text { Omega/ } \\
\text { TMQSS-125G-6 }\end{array}$ & $\begin{array}{c} \pm 1^{\circ} \mathrm{F} \text { or } \\
0.4 \%\end{array}$ \\
\hline F1 & $\begin{array}{c}\text { Within } 3 \mathrm{ft} \text { of } \mathrm{AHU} \\
\text { water inlet }\end{array}$ & $\begin{array}{l}\text { Heating loop } \\
\text { water flow }\end{array}$ & $\begin{array}{l}\text { Water flow } \\
\text { meter }\end{array}$ & $\begin{array}{c}\text { Seametrics/SEB- } \\
075\end{array}$ & $\pm 1 \%$ \\
\hline F2 & $\begin{array}{c}\text { After mixing valve } \\
\text { within } 3 \mathrm{ft} \text { of mixing } \\
\text { valve }\end{array}$ & DHW flow & $\begin{array}{l}\text { Water flow } \\
\text { meter }\end{array}$ & $\begin{array}{c}\text { Seametrics/SEB- } \\
075\end{array}$ & $\pm 1 \%$ \\
\hline F3 & Gas line inlet & $\begin{array}{l}\text { Natural gas } \\
\text { flow }\end{array}$ & $\begin{array}{l}\text { Existing gas } \\
\text { meter }\end{array}$ & $\begin{array}{c}\text { American Meter/ } \\
\text { AC-250 }\end{array}$ & $\pm 1 \%$ \\
\hline $\mathbf{J 1}$ & $\begin{array}{l}\text { Electric meter on } \\
\text { inlet power line to } \\
\text { water heater }\end{array}$ & $\begin{array}{l}\text { Tankless } \\
\text { electrical } \\
\text { power }\end{array}$ & Electric meter & $\begin{array}{c}\text { Continental } \\
\text { Controls/ } \\
\text { WNB-3Y-208-P }\end{array}$ & $\pm 1 \%$ \\
\hline $\mathbf{J} 2$ & $\begin{array}{l}\text { Electric meter on } \\
\text { inlet power line to } \\
\text { air handler }\end{array}$ & $\begin{array}{l}\text { AHU } \\
\text { electrical } \\
\text { power }\end{array}$ & Electric meter & $\begin{array}{c}\text { Continental } \\
\text { Controls/ } \\
\text { WNB-3Y-208-P }\end{array}$ & $\pm 1 \%$ \\
\hline
\end{tabular}

\subsection{Data Collection and Performance Calculations}

After the combi systems were installed, GTI visited each site to install a Logic Beach data logger that was connected to a cell modem. The arrangements allow for downloading of data at any time, changes to the program at any time, and live looks at the system to monitor performance.

Sensors were monitored and recorded every 5 seconds during DHW draws. When DHW was not being drawn, sensors recorded every 30 seconds. Data were transmitted to GTI via cell phone modem and downloaded weekly for 1 year for each site. Monthly and cumulative performance calculations included the following:

- Gas energy consumed

- Electric energy consumed

- Energy delivered to domestic hot water

- Energy delivered to SH

- System efficiency

- Hot water consumed by volume. 
All performance efficiencies were calculated by dividing total energy delivered to DHW and $\mathrm{SH}$ by total gas and electric energy consumed by the water heater and heat distribution system.

Efficiency calculations were as follows:

- Efficiency $=(\mathrm{QW}+\mathrm{QA}) /(\mathrm{QG}+\mathrm{QE})$ : where,

- $\mathrm{QW}=$ Energy delivered to DHW $(\mathrm{Btu} / \mathrm{h})$

○ $\mathrm{QW}=499.8 \times \mathrm{FW} \times(\mathrm{TDHW}-\mathrm{TCW})$ : where,

- $\mathrm{FW}=\mathrm{DHW}$ flow (gpm)

- $\quad$ TDHW $=$ Water heater DHW outlet temperature $\left({ }^{\circ} \mathrm{F}\right)$

- $\mathrm{TCW}=$ City water supply temperature $\left({ }^{\circ} \mathrm{F}\right)$

- $\mathrm{QA}=$ Energy delivered to $\mathrm{SH}(\mathrm{Btu} / \mathrm{h})$

○ $\mathrm{QA}=499.8 \times \mathrm{FA} \times\left(\mathrm{T}_{\text {in }}-\mathrm{T}_{\text {out }}\right)$ : where,

- $\mathrm{FA}=$ Heating water flow (gpm)

- $\mathrm{Tin}=$ Water to $\mathrm{AHU}\left({ }^{\circ} \mathrm{F}\right)$

- $\quad$ Tout $=$ Water from AHU $\left({ }^{\circ} \mathrm{F}\right)$

- $\mathrm{QG}=\mathrm{Gas}$ consumption $(\mathrm{Btu} / \mathrm{h})$

$\circ \mathrm{QG}=\mathrm{FG} \times \mathrm{HHVG}$ : where,

- $\mathrm{FG}=\mathrm{Gas}$ flow (cfh)

- $\mathrm{HHVG}=$ Higher heating value of natural gas

- $\mathrm{QE}=$ Electricity consumption $(\mathrm{Btu} / \mathrm{h})$

○ $\mathrm{QE}=(\mathrm{kWh}+\mathrm{kAH}) \times 3412:$ where,

- $\mathrm{kWh}=$ Water heater electricity $(\mathrm{Wh})$

- $\mathrm{kAH}=$ Air handler electricity $(\mathrm{Wh})$

\subsubsection{Uncertainty of Calculations}

In a worst-case scenario, the uncertainty in overall efficiency calculations could be as high as \pm $3.8 \%$. The uncertainty of all of the flow meters and electric meters was $1 \%$, and the for thermocouples was $1^{\circ} \mathrm{F}$ or $0.4 \%$. Temperature measurements were $40^{\circ}-160^{\circ} \mathrm{F}$, and the thermocouple error corresponding to that range would be $\pm 0.16^{\circ}-0.64^{\circ} \mathrm{F}$. The following are uncertainty estimates for energy delivered, energy supplied, and overall efficiency assuming the maximum error for the thermocouples.

\subsubsection{Uncertainty in Energy Delivered to Domestic Hot Water and Space Heating Calculations}

If a water flow of 0.25 gallons was measured over a 5 -second time period ( $3 \mathrm{gpm}$ ) with a maximum temperature differential of $70^{\circ} \mathrm{F}$, assuming $140^{\circ} \mathrm{F}$ delivered water and $70^{\circ} \mathrm{F}$ supply water, the energy delivered to DHW would be:

- $\mathrm{QW}=8.33 * 0.25 *(140-70)=145.8 \mathrm{Btu} \pm 1.96 \mathrm{Btu}$ 
The uncertainty is calculated as follows:

- $\Delta \mathrm{QW}=8.33 *(\mathrm{QW} *(\mathrm{TDHW}-\mathrm{TCW}))(* \operatorname{sqrt}((\Delta \mathrm{FW} / \mathrm{FW}) 2+((\operatorname{sqrt}(\Delta \mathrm{TDHW} 2+\Delta \mathrm{TCW} 2))$ $/(\mathrm{TDHW}-\mathrm{TCW})) 2)$

- $\Delta \mathrm{QW}=8.33 *(.25 *(140-70)) * \operatorname{sqrt}((.0025 / .25) 2+((\operatorname{sqrt}((0.56) 2+(0.28) 2)) /(140-70)) 2)$ $=1.96$

Therefore, the uncertainty of the flow is 0.0025 gallons and the uncertainties for the temperatures are $0.28^{\circ} \mathrm{F}$ and $0.56^{\circ} \mathrm{F}$ for $140^{\circ} \mathrm{F}$ and $70^{\circ} \mathrm{F}$, respectively. This would be the uncertainty for a large domestic water flow in a 5-second period. Most flows would have a lower flow total and associate uncertainty. If this flow were seen for 15 minutes, then the total and error for that 15minute period would be $26,244 \mathrm{Btu}$ delivered $\pm 353 \mathrm{Btu}$. In this case, the uncertainty in the water heater energy delivered calculation would be $\pm 1.3 \%$.

For the AHU flow, the uncertainty calculation would be:

- $\mathrm{QA}=8.33 * .4 *(140-110)=100 \mathrm{Btu} \pm 2.58 \mathrm{Btu}$

The uncertainty is calculated as follows:

- $\Delta \mathrm{QA}=8.33 *(\mathrm{FA} *(\operatorname{Tin}-\mathrm{Tout}))(* \operatorname{sqrt}((\Delta \mathrm{FA} / \mathrm{FA}) 2+((\operatorname{sqrt}(\Delta \operatorname{Tin} 2+\Delta \operatorname{Tout} 2)) /(\operatorname{Tin}-$ Tout))2)

- $\Delta \mathrm{QA}=8.33 *(.4 *(140-110)) * \operatorname{sqrt}((.004 / .4) 2+((\operatorname{sqrt}((0.56) 2+(0.44) 2)) /(140-110)) 2)$ $=2.58$

Therefore, the uncertainty of the flow is \pm 0.004 gal and the uncertainties for the temperatures are $0.44^{\circ} \mathrm{F}$ and $0.56^{\circ} \mathrm{F}$ for $140^{\circ} \mathrm{F}$ and $110^{\circ} \mathrm{F}$, respectively. This would be the uncertainty for a typical AHU flow in a 5-second period. If this flow were seen for 15 minutes, then the total and error for that 15-minute period would be 18,000 Btu delivered $\pm 464 \mathrm{Btu}$. In this case the uncertainty in the air handler energy delivered calculation would be $2.6 \%$.

\subsubsection{Uncertainty in Electric and Gas Energy Consumed Calculations}

Typical electric energy consumption for a water heater would be about $0.5 \mathrm{Wh}$ for 1 minute of on-time and $9 \mathrm{Wh}$ for the AHU for 1 minute of on-time. For the electric energy use, the uncertainty calculation would be:

- $\mathrm{QE}=(\mathrm{kWWH}+\mathrm{kAH}) \times 3.412$

- $\mathrm{QE}=(1+9) * 3.412=34 \mathrm{Btu} \pm 0.31 \mathrm{Btu}$

The uncertainty is calculated as follows:

- $\Delta \mathrm{QE}=3.412 *(\operatorname{sqrt}(\Delta \mathrm{kWWH} 2+\Delta \mathrm{kAH} 2))$

- $\Delta \mathrm{QE}=3.412 *(\operatorname{sqrt}(0.012+0.092))=0.31$

Therefore, the uncertainty for the water heater electricity is $0.01 \mathrm{Wh}$ and the uncertainty for the AHU is $0.09 \mathrm{Wh}$. This would be the uncertainty for 1-minute of on-time for the water heater or 
AHU. If this occurred for 15 minutes, then the total and error for that 15 -minute period would be 510 Btu delivered $\pm 4.7 \mathrm{Btu}$. In this case the uncertainty in the electricity usage calculation would be $0.92 \%$.

Typical gas energy consumption for a simultaneous 15-minute DHW draw and AHU demand as described above would be $47.7 \mathrm{ft}^{3}$ in a 15 -minute on-time period. GTI did not measure the natural gas heating value at each site so a general estimate of $1,020 \mathrm{Btu} / \mathrm{ft}^{3}$ was used. That assumption generates additional error; heating values would not be expected to fall out of the range of 1000-1040, meaning the heating value should be \pm 20 . For the gas energy use, the uncertainty calculation would be:

- $\mathrm{Q}_{\mathrm{G}}=\mathrm{F}_{\mathrm{G}} \times \mathrm{HHV}_{\mathrm{G}}$

- $\mathrm{Q}_{\mathrm{G}}=47.7 * 1020=48654 \mathrm{Btu} \pm 1071 \mathrm{Btu}$

The uncertainty is calculated as follows:

- $\Delta \mathrm{Q}_{\mathrm{G}}=\mathrm{Q}_{\mathrm{G}} *\left(\operatorname{sqrt}\left(\left(\Delta \mathrm{F}_{\mathrm{G}} / \mathrm{F}_{\mathrm{G}}\right)^{2}+\left(\Delta \mathrm{HHV}_{\mathrm{G}} / \mathrm{HHV}_{\mathrm{G}}\right)^{2}\right)\right)$

- $\Delta \mathrm{Q}_{\mathrm{G}}=48654 *\left(\operatorname{sqrt}\left((0.477 / 47.7)^{2}+(20 / 1020)^{2}\right)\right)=1071$

Therefore, the uncertainty for the gas energy use is 0.477 cubic feet, and the uncertainty for the heating value is $20 \mathrm{Btu} / \mathrm{ft}^{3}$. This would be the uncertainty for 15 minutes of on-time for the water heater. In this case the uncertainty in the gas usage calculation would be $\pm 2.2 \%$.

\subsubsection{Uncertainty in Overall Efficiency Calculations}

The efficiency could be calculated by the following formula:

- Efficiency $=\left(\mathrm{Q}_{\mathrm{W}}+\mathrm{Q}_{\mathrm{A}}\right) /\left(\mathrm{Q}_{\mathrm{G}}+\mathrm{Q}_{\mathrm{E}}\right)$

- Efficiency $=(26,244+18,000) /(48,654+510)=0.9 \pm 0.034=90.0 \% \pm 3.4 \%$

The uncertainty is calculated as follows:

- $\Delta$ Efficiency $=$ Eff $* \operatorname{sqrt}\left(\left(\Delta \mathrm{QW}_{\mathrm{W}} / \mathrm{Qw}^{2}+\left(\Delta \mathrm{Q}_{\mathrm{A}} / \mathrm{Q}_{\mathrm{A}}\right)^{2}+\left(\Delta \mathrm{Q}_{\mathrm{G}} / \mathrm{Q}_{\mathrm{G}}\right)^{2}+\left(\Delta \mathrm{Q}_{\mathrm{E}} / \mathrm{Q}_{\mathrm{E}}\right)^{2}\right)\right.$

- $\Delta$ Efficiency $=0.9 * \operatorname{sqrt}\left((353 / 26244)^{2}+(464 / 18000)^{2}+(1071 / 48654)^{2}+(4.7 / 510)^{2}\right)=$ 0.034

This would be the uncertainty for 15 minutes of on-time for the water heater where a SH and water heating event are taking place simultaneously. In this case, the total uncertainty in the efficiency calculation would be $\pm 3.8 \%$.

\subsection{Energy Savings Calculation Methodology}

Two methods were used to determine energy savings: utility billing and baseline nameplate efficiency operation by the nameplate efficiencies of the baseline equipment. The first method is often used because it is based on the site's actual baseline gas usage. However, given the relatively small size of the Nicor and NYSERDA pilots, and the lack of historical billing information for some of the pilot sites retrofitted with the combi systems, the nameplate method was used to report the therm savings. 


\subsubsection{Utility Billing and Heating Degree Day Savings Calculations}

Gas utility bill analysis prior to installation provides insight into the heating requirements of the site. Whenever possible, billing analyses were provided to the installing contractors prior to their formal in-home assessments.

Baseline SH natural gas use was determined through linear regression analyses, comparing about 24 months of past utility bills to the site's corresponding heating degree days (HDDs). HDD base-temperatures between $59^{\circ} \mathrm{F}$ and $69^{\circ} \mathrm{F}$ were generated, and the correlation coefficient $\left(\mathrm{R}^{2}\right)$ to the historical gas usage was calculated. The base temperatures with the highest correlation coefficient to gas usages were selected as the most appropriate base temperatures for the homes (See Figure 4 for example). Building data with significant randomness (e.g., $\mathrm{R}^{2}$ less than 0.90 ) could indicate inconsistent thermostat settings, unknown heating sources, or other changes to the building's thermal insulation. Any uncertainties related to these factors would complicate the comparison of combi savings relative to the base case usage.

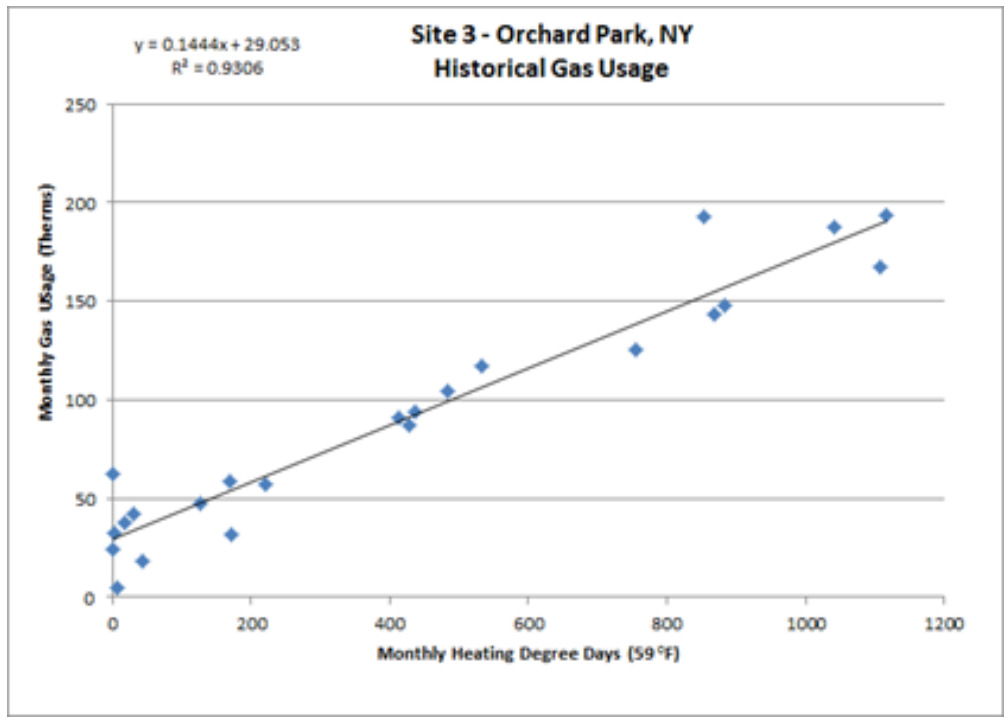

Figure 4. Billing analysis example

The linear regression equation calculates the site's total baseline natural gas consumption, and therefore includes baseline SH, DHW, and any other gas-consuming appliances (cooktop, dryer, etc.). The equation uses actual HDDs during the monitoring period, and are determined using a third-party data source (degreedays.net). To calculate the gas consumed for baseline SH only, the baseline DHW gas consumption, and the gas consumption from other appliances must be subtracted from the linear regression equation.

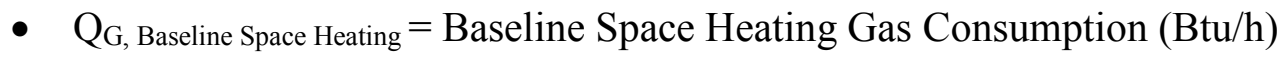

○ $\mathrm{Q}_{\mathrm{G}, \text { Baseline Space Heating }}=$ Linear Regression Equation $-\mathrm{Q}_{\mathrm{G}, \text { Baseline } \mathrm{DHW}}-\mathrm{Q}_{\mathrm{G}}$, Other: where

- $\mathrm{Q}_{\mathrm{G}, \text { Baseline DHW }}=$ Baseline DHW Gas Consumption $(\mathrm{Btu} / \mathrm{h})$

- $\mathrm{Q}_{\mathrm{G}, \text { Baseline } \mathrm{DHW}}=\frac{\text { Energy Delivered to DHW }}{\text { Pre-retrofit water heater nameplate efficiency }}$ 
- $\mathrm{Q}_{\mathrm{G}, \text { Other }}=$ Other Gas Appliance Usage (cooktop, dryer, etc.) (Btu/h)

During the summer months, it is assumed that no gas is consumed for $\mathrm{SH}$, and therefore, the gas consumption is for DHW and other gas-consuming appliances (cooktop, dryer, etc.).

- $\mathrm{Q}_{\mathrm{G}, \text { Other }}=$ Summer Months Gas Consumption - $\mathrm{Q}_{\mathrm{G} \text {, Baseline DHW }}$

The monitored value $\mathrm{Q}_{\mathrm{G}}$ is the sum of the gas consumption for both $\mathrm{DHW}$ and $\mathrm{SH}$. To determine the gas consumption for SH only $\left(\mathrm{Q}_{\mathrm{G}}\right.$, Space Heating $)$ or DHW only $\left(\mathrm{Q}_{\mathrm{G}}\right.$, DHW $)$, the energy delivered to SH or DHW is divided by the monitored gas-only efficiency.

$$
\begin{aligned}
\circ \mathrm{Q}_{\mathrm{G}} & =\mathrm{Q}_{\mathrm{G}, \text { Space Heating }}+\mathrm{Q}_{\mathrm{G}, \text { DHW: }} \text { where } \\
\text { - } & \mathrm{Q}_{\mathrm{G}, \text { Space Heating }}=\text { Post-Retrofit Space Heating Gas Usage }(\mathrm{Btu} / \mathrm{h}) \\
\text { - } & \mathrm{Q}_{\mathrm{G}, \text { Space Heating }}=\frac{\text { Energy delivered to space heating }}{\text { Gas-Only Efficiency }} \\
\text { - } & \mathrm{Q}_{\mathrm{G}, \mathrm{DHW}}=\text { Post-Retrofit DHW Gas Usage }(\mathrm{Btu} / \mathrm{h}) \\
\text { - } & \mathrm{Q}_{\mathrm{G}, \mathrm{DHW}}=\frac{\text { Energy delivered to DHW }}{\text { Gas-Only Efficiency }}
\end{aligned}
$$

The gas savings is determined by subtracting the monitored gas consumption $\left(\mathrm{Q}_{\mathrm{G}}\right)$ from the baseline gas consumption for SH and DHW ( $Q_{G}$, Baseline Space Heating and $Q_{G}$, Baseline DHW).

\subsubsection{Pre-Retrofit Nameplate Efficiency Savings Calculations}

Pre-retrofit gas usage was estimated by dividing monitored SH and DHW energy delivered by predetermined nameplate efficiencies of typical pre-retrofit equipment. This methodology simplifies savings calculations and is used here because pre-retrofit appliance gas usage were not available. The underlying assumptions in estimating savings this way are that the pre-retrofit appliances operated at nameplate efficiencies and that delivered energy for SH and DHW is the same before and after the retrofit.

\subsection{Host Site Combi System Configurations}

Collectively, seven different combi systems were installed and monitored across 10 sites for NYSERDA and five sites for Nicor. Brief descriptions of all seven systems are listed below (Systems A through G). For the Nicor ETP, one combi technology (System B) was selected for field testing and pilot assessments. All five systems were monitored and installed in installing contractors homes or shops for evaluation. All seven combi technologies (Systems A-G) were selected for field demonstrations under the NYSERDA field testing project.

- System A - Integrated appliance tankless-AHU combi system

- System B - Integrated appliance tankless-AHU combi system

- System C-Combi boiler system

- System D - Separate tankless plus third-party AHU combi system

- System E - Separate tankless plus third-party AHU combi system

- System F - Separate tankless plus third-party AHU combi system 
- System $\mathrm{G}$ - Hybrid solar thermal collector with separate tankless plus third-party AHU combi system.

For this report, only cursory notes are provided for the two NYSERDA demonstration sites that used Systems C and G. The focus of this report is on forced-air combis without a solar component. System C is for a radiant boiler application and System G is solar assisted.

\subsection{Pilot Host Site Selection}

GTI conducted host site recruitment for pilot sites under the Nicor ETP pilot program; the NYSERDA demonstration project; the SoCal ETP pilot program; and the UIL demonstration project through its ETPs. Key goals for the demonstrations and pilots were to educate installing contractors and prepare them for marketing and selling the product as they would any other HVAC system. That process allowed the contractors to conduct load calculations, make systems selections, and install them with only minimal involvement by GTI, other than for the special monitoring instrumentation and associated equipment.

Prescreening worksheets were completed by the contractors for GTI's review and any subsequent utility billing analyses. Once approved, the contractors conducted heating load calculations and system selections that were provided to the manufacturers for verification. Field Test Agreements between GTI and the homeowners were put in place prior to manufacturer delivery of the equipment. The contractors installed the systems per the manufacturer's Installation Manuals and per GTI's Measurement and Verification (M\&V) Plan. Once the systems were commissioned by the contractor, GTI conducted site visits to verify proper instrumentation installation, and to install and commission the data acquisition systems (DAQ).

\subsubsection{Nicor Host Site Summaries}

Table 2 summarizes each of the five Nicor pilot sites, including characteristics of each home and its occupants; the existing SH and water heating equipment; and the new combi system that was installed.

\subsubsection{NYSERDA Host Site Summaries}

Tables 3 and 4 summarize each of the 10 NYSERDA pilot sites, including characteristics of each home and its occupants; the existing SH and water heating equipment; and the new combi system that was installed. 
Table 2. Nicor Host Site Descriptions

\begin{tabular}{|c|c|c|c|c|c|}
\hline Nicor Sites & Site 1 & Site 2 & Site 3 & Site 4 & Site 5 \\
\hline Illinois Location & Westchester & Glen Ellyn & Hoffman Est. & Libertyville & Oswego \\
\hline Weatherized & Yes & No & Yes & \multirow{17}{*}{$\begin{array}{c}\text { Site } 4 \text { is a } \\
\text { commercial } \\
\text { site. }\end{array}$} & Yes \\
\hline Type & 2-story & Ranch & Ranch & & 2-story \\
\hline Square Feet & 1,826 & 4,300 & 1,500 & & 3,279 \\
\hline Built & 1948 & 1959 & 1957 & & 2006 \\
\hline Water & Municipal & Municipal & Municipal & & Municipal \\
\hline Occupants & 2 & 2 & 5 & & 4 \\
\hline Showers per Week & 14 & NA & 14 & & NA \\
\hline Baths or Whirlpools per Week & 0 & NA & 0 & & NA \\
\hline Dishwashing Cycles per Day & 1 & NA & 1 & & NA \\
\hline Laundry Loads per Week & 3 & NA & 30 & & NA \\
\hline Furnace/Boiler Age & 20 yrs & $21 \mathrm{yrs}$ & 4 yrs & & NA \\
\hline Furnace/Boiler Size & NA & $132 \mathrm{kBtu} / \mathrm{h}$ & $80 \mathrm{kBtu} / \mathrm{h}$ & & NA \\
\hline $\begin{array}{c}\text { Furnace/Boiler Rated } \\
\text { Efficiency }\end{array}$ & $70 \%$ AFUE & $80 \%$ AFUE & $80 \%$ AFUE & & NA \\
\hline Water Heater Age & $15 \mathrm{yrs}$ & $5 \mathrm{yrs}$ & $6 \mathrm{yrs}$ & & NA \\
\hline Water Heater Gallons & 55 & Tankless & 50 & & NA \\
\hline Water Heater Size & $36 \mathrm{kBtu} / \mathrm{h}$ & $199 \mathrm{kBtu} / \mathrm{h}$ & $65 \mathrm{kBtu} / \mathrm{h}$ & & NA \\
\hline Water Heater Rated Efficiency & $0.52 \mathrm{EF}$ & $0.82 \mathrm{EF}$ & $0.58 \mathrm{EF}$ & & NA \\
\hline Combi System & $\mathrm{B}$ & B & $\mathrm{B}$ & B & B \\
\hline Combi Water Heater Size & $199 \mathrm{kBtu} / \mathrm{h}$ & $199 \mathrm{kBtu} / \mathrm{h}$ & $199 \mathrm{kBtu} / \mathrm{h}$ & $199 \mathrm{kBtu} / \mathrm{h}$ & $199 \mathrm{kBtu} / \mathrm{h}$ \\
\hline Combi In-Situ Efficiency & 0.94 & 0.94 & 0.94 & 0.94 & 0.94 \\
\hline AHU Type & Integrated & Integrated & Integrated & Integrated & Integrated \\
\hline AHU Size & $79.8 \mathrm{kBtu} / \mathrm{h}$ & $79.8 \mathrm{kBtu} / \mathrm{h}$ & $79.8 \mathrm{kBtu} / \mathrm{h}$ & $79.8 \mathrm{kBtu} / \mathrm{h}$ & $79.8 \mathrm{kBtu} / \mathrm{h}$ \\
\hline $\begin{array}{c}\text { AHU Size Entering Water } \\
\text { Temperature }\end{array}$ & $160^{\circ} \mathrm{F}$ & $160^{\circ} \mathrm{F}$ & $160^{\circ} \mathrm{F}$ & $160^{\circ} \mathrm{F}$ & $160^{\circ} \mathrm{F}$ \\
\hline Design-Day Gas Use & NA & NA & NA & NA & NA \\
\hline Design-Day Capacity Estimate & NA & NA & NA & NA & NA \\
\hline Contractor Sizing & NA & NA & NA & NA & NA \\
\hline Installation Cost & NA & NA & NA & NA & NA \\
\hline
\end{tabular}


Table 3. NYSERDA Host Sites 1 Through 5 Descriptions

\begin{tabular}{|c|c|c|c|c|c|}
\hline NYSERDA Sites & Site 1 & Site 2 & Site 3 & Site 4 & Site 5 \\
\hline New York Location & Balston Spa & Warsaw & Orchard Park & East Syracuse & Marilla \\
\hline Weatherized & Yes & Yes & Yes & Yes & Yes \\
\hline Type & Low-rise & Split & 2-story & 2-story & 2-story \\
\hline Square Feet & 2,709 & 1,500 & 2,500 & 2,100 & 2,500 \\
\hline Built & 2013 & 1950 & 1990 & 1967 & 1964 \\
\hline Water & Municipal & Municipal & Municipal & Municipal & Municipal \\
\hline Occupants & 2 & 1 & 5 & 4 & 5 \\
\hline Showers per Week & 14 & 8 & 64 & 24 & 31 \\
\hline Baths or Whirlpool per Week & 0 & 0 & 0 & 0 & 0 \\
\hline Dishwashing Cycles per Day & By hand & 1 & $1-2$ & $1-2$ & 1 \\
\hline Laundry Loads per Week & 4 & 5 & $22-27$ & $22-27$ & $5-7$ \\
\hline Furnace/Boiler Age & NA & $22 \mathrm{yrs}$ & 22 yrs & $22 \mathrm{yrs}$ & $40+$ yrs \\
\hline Furnace/Boiler Size & NA & N/A & $75 \mathrm{kBtu} / \mathrm{h}$ & $75 \mathrm{kBtu} / \mathrm{h}$ & $135.5 \mathrm{kBtu} / \mathrm{h}$ \\
\hline $\begin{array}{c}\text { Furnace/Boiler Rated } \\
\text { Efficiency }\end{array}$ & NA & $80 \%$ AFUE & $80 \%$ AFUE & $80 \%$ AFUE & 70\% AFUE \\
\hline Water Heater Age & NA & $6 \mathrm{yrs}$ & $6.5 \mathrm{yrs}$ & $6.5 \mathrm{yrs}$ & $1 \mathrm{yr}$ \\
\hline Water Heater Gallons & NA & 55 & 40 & 40 & 40 \\
\hline Water Heater Size & NA & $28 \mathrm{kBtu} / \mathrm{h}$ & $40 \mathrm{kBtu} / \mathrm{h}$ & $40 \mathrm{kBtu} / \mathrm{h}$ & $40 \mathrm{kBtu} / \mathrm{h}$ \\
\hline Water Heater Rated Efficiency & NA & $0.57 \mathrm{EF}$ & $0.58 \mathrm{EF}$ & $0.58 \mathrm{EF}$ & $0.62 \mathrm{EF}$ \\
\hline Combi System & $\mathrm{G}$ & A & A & A & $\mathrm{C}$ \\
\hline Combi Water Heater Size & $199 \mathrm{kBtu} / \mathrm{h}$ & $152 \mathrm{kBtu} / \mathrm{h}$ & $152 \mathrm{kBtu} / \mathrm{h}$ & $199 \mathrm{kBtu} / \mathrm{h}$ & $110 \mathrm{kBtu} / \mathrm{h}$ \\
\hline Combi In-Situ Efficiency & 0.93 & 0.96 & 0.96 & 0.96 & 0.96 \\
\hline AHU Type & Third-party & Integrated & Integrated & Integrated & NA \\
\hline AHU Size & $58 \mathrm{kBtu} / \mathrm{h}$ & $75.8 \mathrm{kBtu} / \mathrm{h}$ & $75.8 \mathrm{kBtu} / \mathrm{h}$ & $75.8 \mathrm{kBtu} / \mathrm{h}$ & NA \\
\hline $\begin{array}{c}\text { AHU Size Entering Water } \\
\text { Temperature }\end{array}$ & $140^{\circ} \mathrm{F}$ & $160^{\circ} \mathrm{F}$ & $160^{\circ} \mathrm{F}$ & $160^{\circ} \mathrm{F}$ & NA \\
\hline Design-Day Gas Use & NA & $31 \mathrm{kBtu} / \mathrm{h}$ & $41.5 \mathrm{kBtu} / \mathrm{h}$ & $41.5 \mathrm{kBtu} / \mathrm{h}$ & $55.5 \mathrm{kBtu} / \mathrm{h}$ \\
\hline Design-Day Capacity Estimate & NA & $25.2 \mathrm{kBtu} / \mathrm{h}$ & $34.6 \mathrm{kBtu} / \mathrm{h}$ & $34.6 \mathrm{kBtu} / \mathrm{h}$ & $46.3 \mathrm{kBtu} / \mathrm{h}$ \\
\hline Contractor Sizing & $14.6 \mathrm{kBtu} / \mathrm{h}$ & $63.5 \mathrm{kBtu} / \mathrm{h}$ & $40.9 \mathrm{kBtu} / \mathrm{h}$ & $40.9 \mathrm{kBtu} / \mathrm{h}$ & $54.9 \mathrm{kBtu} / \mathrm{h}$ \\
\hline Installation Cost & NA & $\$ 3,300$ & $\$ 3,400$ & $\$ 3,400$ & $\$ 3,510$ \\
\hline
\end{tabular}


Table 4. NYSERDA Host Sites 6 Through 10 Descriptions

\begin{tabular}{|c|c|c|c|c|c|}
\hline NYSERDA Sites & Site 6 & Site 7 & Site 8 & Site 9 & Site 10 \\
\hline New York Location & Syracuse & Ithaca & Ballston Spa & Binghamton & Syracuse \\
\hline Weatherized & Yes & Yes & Yes & Yes & Yes \\
\hline Type & 2-story & 1.5-story & 2-story & Ranch & 2-story \\
\hline Square Feet & 1,580 & 1,307 & 2,400 & 2,300 & 1,800 \\
\hline Built & 1920 & 1955 & 1992 & 1993 & 1930 \\
\hline Water & Municipal & Municipal & Well & Municipal & Municipal \\
\hline Occupants & 4 & 5 & 2 & 6 & 2 \\
\hline Showers per Week & 28 & 25 & 14 & 10 & 14 \\
\hline Baths or Whirlpools per Week & 0 & 0 & 0 & 0 & 0 \\
\hline Dishwashing Cycles per Day & NA & $1-2$ & 1 & $1-2$ & 1 \\
\hline Laundry Loads per Week & By hand & 5 & 3 & 12 & 5 \\
\hline Furnace/Boiler Age & $6.5 \mathrm{yrs}$ & 18 yrs & $1 \mathrm{yr}$ & 19 yrs & 19 yrs \\
\hline Furnace/Boiler Size & $84 \mathrm{kBtu} / \mathrm{h}$ & $58 \mathrm{kBtu} / \mathrm{h}$ & $115 \mathrm{kBtu} / \mathrm{h}$ & $90 \mathrm{kBtu} / \mathrm{h}$ & $70 \mathrm{kBtu} / \mathrm{h}$ \\
\hline $\begin{array}{c}\text { Furnace/Boiler Rated } \\
\text { Efficiency }\end{array}$ & $80 \%$ AFUE & $80 \%$ AFUE & $80 \%$ AFUE & $80 \%$ AFUE & $78 \%$ AFUE \\
\hline Water Heater Age & $6.5 \mathrm{yrs}$ & $5 \mathrm{yrs}$ & $1 \mathrm{yr}$ & $5 \mathrm{yrs}$ & $19 \mathrm{yrs}$ \\
\hline Water Heater Gallons & 40 & 40 & 40 & 40 & 40 \\
\hline Water Heater Size & $40 \mathrm{kBtu} / \mathrm{h}$ & $34 \mathrm{kBtu} / \mathrm{h}$ & NA & $40 \mathrm{kBtu} / \mathrm{h}$ & $40 \mathrm{kBtu} / \mathrm{h}$ \\
\hline Water Heater Rated Efficiency & $0.59 \mathrm{EF}$ & $0.58 \mathrm{EF}$ & $0.62 \mathrm{EF}$ & $0.58 \mathrm{EF}$ & $0.54 \mathrm{EF}$ \\
\hline Combi System & $\mathrm{B}$ & $\mathrm{D}$ & E & $\mathrm{F}$ & A \\
\hline Combi Water Heater Size & $199 \mathrm{kBtu} / \mathrm{h}$ & 199 kBtu/h & $195 \mathrm{kBtu} / \mathrm{h}$ & 199 kBtu/h & $152 \mathrm{kBtu} / \mathrm{h}$ \\
\hline Combi In-Situ Efficiency & 0.94 & 0.95 & 0.96 & 0.94 & 0.96 \\
\hline AHU Type & Integrated & Third-party & Third-party & Third-party & Integrated \\
\hline AHU Size & $79.8 \mathrm{kBtu} / \mathrm{h}$ & $58.3 \mathrm{kBtu} / \mathrm{h}$ & $60 \mathrm{kBtu} / \mathrm{h}$ & $60 \mathrm{kBtu} / \mathrm{h}$ & $75.8 \mathrm{kBtu} / \mathrm{h}$ \\
\hline $\begin{array}{c}\text { AHU Size Entering Water } \\
\text { Temperature }\end{array}$ & $160^{\circ} \mathrm{F}$ & $180^{\circ} \mathrm{F}$ & $140^{\circ} \mathrm{F}$ & $140^{\circ} \mathrm{F}$ & $160^{\circ} \mathrm{F}$ \\
\hline Design-Day Gas Use & NA & $63.9 \mathrm{kBtu} / \mathrm{h}$ & $33.8 \mathrm{kBtu} / \mathrm{h}$ & NA & $45.5 \mathrm{kBtu} / \mathrm{h}$ \\
\hline Design-Day Capacity Estimate & NA & $51.0 \mathrm{kBtu} / \mathrm{h}$ & $27.0 \mathrm{kBtu} / \mathrm{h}$ & NA & $37.9 \mathrm{kBtu} / \mathrm{h}$ \\
\hline Contractor Sizing & $58.9 \mathrm{kBtu} / \mathrm{h}$ & $45.1 \mathrm{kBtu} / \mathrm{h}$ & $52.4 \mathrm{kBtu} / \mathrm{h}$ & $45.4 \mathrm{kBtu} / \mathrm{h}$ & $61.9 \mathrm{kBtu} / \mathrm{h}$ \\
\hline Installation Cost & NA & $\$ 3,211$ & NA & NA & NA \\
\hline
\end{tabular}




\subsubsection{NYSERDA Site 1 Cursory Notes}

NYSERDA Site 1 was a solar assisted combi system, and was included in the GreenHomeNYC Fall 2013 Green Building Tour. The site was identified through NYSERDA's ENERGY STAR ${ }^{\circledR}$ Homes Program and the home was built by one of the program's Low-Rise Residential New Construction Partners.

The combi System G included a hybrid solar thermal collector with a separate water heater along with a third-party AHU. The solar hybrid combi system incorporated two evacuated tube solar thermal collectors, a double-shell construction 80-gallon storage tank, a condensing tankless water heater, and a third-party variable-speed hydronic AHU. The AHU was also equipped with an integrated heat recovery ventilator. The solar hybrid combi system required manufacturer's coordination to match the solar thermal, tankless water heater, and AHU equipment.

The builder was a participant in NYSERDA's New York ENERGY STAR Homes program, and the home was subject to NYSERDA's high performance requirements under that program. For this system, the homeowner requested a heat recovery ventilator to be part of the AHU.

\subsubsection{NYSERDA Site 5 Cursory Notes}

NYSERDA Site 5 was the only combi boiler of the 15 monitored sites for Nicor and NYSERDA. The combi boiler was installed in a radiant hot water system and replaced a traditional hot water boiler.

The manufacturer of the combi boiler for Site 5 also makes tankless water heaters for forced-air combi systems. Together with GTI and the utility partner, the manufacturer wanted to better understand in-field performance of that system and highlight its potential value. A gas utility employee offered their home as a host site for detailed monitoring of the system. 


\section{Results}

\subsection{Installation and Commissioning}

Combi systems at the Nicor pilot sites were installed between January 2013 and October 2013, and at the NYSERDA pilot sites between December 2012 and October 2013. There were 45 sitemonths of data acquired across the five Nicor sites, and 90 site-months of data acquired across the eight NYSERDA sites.

All of the pilot sites in the Nicor pilot utilized the same integrated appliance tankless-AHU combi systems (System B). Nicor Sites 1, 2, 3, and 5 were installing-contractors homes and those contractors were provided formal combi training by the manufacturer and GTI. Nicor Site 4 was an HVAC shop that was used to evaluate the combi system and to allow the HVAC contractor to showcase the technology. All of the NYSERDA sites were installed in gas utility customer's homes.

The combi field test installations for this study, including Nicor and NYSERDA, were monitored "as-is" to ascertain contractor knowledge, installation practices, and performance of combisystems. While the contractors were encouraged to adhere to the installation practices provide to them during the training session, the installation practices were not enforced by the manufacturers or GTI. Subsequent to the installations, GTI made observations regarding the contractor's conformance with plumbing and HVAC methods, and system settings provided to them in training.

\subsection{Cumulative Energy Savings}

Of the 13 Nicor and NYSERDA pilot sites, GTI was able to gather historical billing data from eight sites. Table 5 summarizes results of utility billing and HDD cumulative therm savings calculations. These HDD calculations provide insight toward actual baseline gas usage and savings for the pilot sites. However, utility ETPs/EEPs often require an understanding of how much savings could be achieved from predetermined baselines consistent across sites. Therefore energy savings were calculated using predetermined nameplate efficiencies of typical pre-retrofit equipment as described in Section 3.3.

Table 5. Nicor and NYSERDA Pilot Site Cumulative Energy Savings

\begin{tabular}{c|c|c|c}
\hline Site & $\begin{array}{c}\text { Months of } \\
\text { Data }\end{array}$ & $\begin{array}{c}\text { Therm } \\
\text { Savings }\end{array}$ & $\begin{array}{c}\text { Percent } \\
\text { Savings }\end{array}$ \\
\hline Nicor 2 & 13 & 203 & $12 \%$ \\
Nicor 3 & 11 & 231 & $18 \%$ \\
NYSERDA 2 & 12 & 179 & $16 \%$ \\
NYSERDA 3 & 11 & 218 & $21 \%$ \\
NYSERDA 4 & 12 & 65 & $8 \%$ \\
NYSERDA 7 & 12 & 513 & $38 \%$ \\
NYSERDA 8 & 9 & 285 & $32 \%$ \\
NYSERDA 10 & 12 & 181 & $21 \%$ \\
\hline
\end{tabular}




\subsection{Energy Savings From Predetermined Baselines}

From the five Nicor sites, 45 site-months of data were collected over consecutive months (for up to 12 full months) as shown in Table 6. An additional 90 site-months of data were collected from eight supplemental NYSERDA sites as shown in Table 6 as well. For months where representative site-month data were not collected (as shown in red in Table 6), linear regression techniques were used to estimate annualized energy consumptions and efficiencies using data from other months for that site. For energy delivered to SH, HDDs and corresponding monthly data were used to generate estimates for the months that were missing. For energy delivered to DHW, historical ground water temperatures and corresponding monthly data were used to generate estimates for the months that were missing.

Table 6. Site-Months of Data (Monitored in Blue)

\begin{tabular}{|c|c|c|c|c|c|c|c|c|c|c|c|c|}
\hline Host Site & Jan & Feb & Mar & Apr & May & Jun & Jul & Aug & Sep & Oct & Nov & Dec \\
\hline Nicor Gas 1 & & & & & & & & & & & & \\
\hline Nicor Gas 2 & & & & & & & & & & & & \\
\hline Nicor Gas 3 & & & & & & & & & & & & \\
\hline Nicor Gas 4 & & & & & & & & & & & & \\
\hline Nicor Gas 5 & & & & & & & & & & & & \\
\hline NYSERDA 2 & & & & & & & & & & & & \\
\hline NYSERDA 3 & & & & & & & & & & & & \\
\hline NYSERDA 4 & & & & & & & & & & & & \\
\hline NYSERDA 6 & & & & & & & & & & & & \\
\hline NYSERDA 7 & & & & & & & & & & & & \\
\hline NYSERDA 8 & & & & & & & & & & & & \\
\hline NYSERDA 9 & & & & & & & & & & & & \\
\hline NYSERDA 10 & & & & & & & & & & & & \\
\hline
\end{tabular}

Energy savings for the Nicor and NYSERDA sites are shown in Table 7. It can be seen that there is a wide range of savings across pilot sites. Tables 8 and 9 summarize the monthly performances of the combi systems at the Nicor and NYSERDA sites.

Per the Nicor pilot data in Table 7 (with the nonresidential Site 4 excluded), an annualized average of 127.5 therms per year, or $9.4 \%$ of DHW and SH gas use was saved with the combi system when compared to a conventional furnace at $80 \%$ AFUE and water heater at $0.59 \mathrm{EF}$. Average therm and \% savings per year were near zero against a 90\% AFUE furnace and $0.59 \mathrm{EF}$ water heater.

It is important to note that for the additional 90 site-months of data collected for eight forced-air combi demonstrations in New York for NYSERDA, three of those combi systems (NYSERDA Sites 7, 8, and 9) were installed with third-party AHUs specifically designed with condensing combi system applications in mind. These AHUs had hydronic coils designed to operate at lower return water to the coupled water heater to achieve condensing efficiencies (combi system efficiencies equal to or greater than $90 \%$ ) while still providing comfortable supply air temperatures. Per the NYSERDA pilot data in Table 8, these three sites consistently achieved high anuualized gas savings of $16.2 \%-22.3 \%$ versus a standard furnace and standard tank water 
heater and $7.2 \%$ to $16.9 \%$ gas savings versus a high-efficiency condensing furnace and standard tank water heater.

Per the NYSERDA pilot data in Table 7, an annualized average of 129.5 therms per year, or $13 \%$ of DHW and SH gas use was saved with the combi system when compared to a conventional furnace at $80 \%$ AFUE and water heater at $0.59 \mathrm{EF}$. 
Table 7. Annualized Pilot Site Energy Usage and Therms Savings

\begin{tabular}{|c|c|c|c|c|c|c|c|c|c|c|c|}
\hline \multirow[b]{2}{*}{ Host Site } & \multicolumn{2}{|c|}{$\begin{array}{c}\text { Delivered } \\
\text { Energy }\end{array}$} & \multicolumn{2}{|c|}{$\begin{array}{l}\text { Combi Energy } \\
\text { Consumed }\end{array}$} & \multicolumn{3}{|c|}{$\begin{array}{l}\text { Baseline Energy } \\
\text { Consumed }\end{array}$} & \multicolumn{2}{|c|}{$\begin{array}{c}\text { Therm Savings } \\
\text { Combi Versus } \\
\text { Baselines }\end{array}$} & \multirow{2}{*}{$\begin{array}{c}\text { Percent } \\
\text { Savings } \\
0.59 \\
\text { DHW } \\
80 \% \mathrm{SH}\end{array}$} & \multirow{2}{*}{$\begin{array}{c}\text { Percent } \\
\text { Savings } \\
0.59 \\
\text { DHW } \\
90 \% \mathrm{SH}\end{array}$} \\
\hline & DHW & SH & DHW & SH & $\begin{array}{c}\text { 0.59 } \\
\text { DHW }\end{array}$ & $\begin{array}{c}80 \% \\
\text { SH }\end{array}$ & $\begin{array}{l}90 \% \\
\text { SH }\end{array}$ & $\begin{array}{c}0.59 \\
\text { DHW } \\
80 \% \\
\text { SH }\end{array}$ & $\begin{array}{c}0.59 \\
\text { DHW } \\
90 \% \\
\text { SH }\end{array}$ & & \\
\hline Nicor Gas 1 & 59.1 & 733.1 & 73.3 & 886.0 & 100.2 & 916.3 & 814.5 & 57.3 & -44.5 & $5.6 \%$ & $-4.9 \%$ \\
\hline Nicor Gas 2 & 121.9 & 1052.1 & 139.0 & 1195.0 & 206.6 & 1315.2 & 1169.0 & 187.8 & 41.6 & $12.3 \%$ & $3.0 \%$ \\
\hline Nicor Gas 3 & 182.0 & 770.3 & 213.2 & 902.4 & 308.5 & 962.9 & 855.9 & 155.7 & 48.8 & $12.2 \%$ & $4.2 \%$ \\
\hline Nicor Gas 4 & 4.6 & 104.4 & 5.2 & 121.9 & 7.9 & 130.5 & 116.0 & 11.2 & -3.3 & $8.1 \%$ & $-2.7 \%$ \\
\hline Nicor Gas 5 & 138.7 & 1001.8 & 166.2 & 1212.0 & 235.0 & 1252.3 & 1113.2 & 109.2 & -29.9 & $7.3 \%$ & $-2.2 \%$ \\
\hline $\begin{array}{c}\text { Nicor Gas Avg } \\
\text { w/o Site } 4 \\
\text { w/Site } 4\end{array}$ & & & & & & & & $\begin{array}{l}\mathbf{1 2 7 . 5} \\
104.2\end{array}$ & $\begin{array}{l}4.0 \\
2.5\end{array}$ & $\begin{array}{l}\mathbf{9 . 4 \%} \\
9.1 \%\end{array}$ & $\begin{array}{c}\mathbf{0 . 0} \% \\
-0.5 \%\end{array}$ \\
\hline NYSERDA 2 & 61.6 & 584.3 & 83.6 & 752.4 & 104.4 & 730.3 & 649.2 & -1.3 & -82.4 & $-0.2 \%$ & $-10.9 \%$ \\
\hline NYSERDA 3 & 212.0 & 652.9 & 250.4 & 710.4 & 386.3 & 816.1 & 725.4 & 241.7 & 151.0 & $20.1 \%$ & $13.6 \%$ \\
\hline NYSERDA 4 & 96.5 & 489.8 & 122.4 & 592.5 & 163.6 & 612.3 & 544.2 & 60.9 & -7.1 & $7.8 \%$ & $-1.0 \%$ \\
\hline NYSERDA 6 & 165.1 & 1217.8 & 201.3 & 1476.8 & 279.9 & 1522.2 & 1353.1 & 124.0 & -45.1 & $6.9 \%$ & $-2.8 \%$ \\
\hline NYSERDA 7 & 122.8 & 614.8 & 137.6 & 662.7 & 208.2 & 768.5 & 683.1 & 176.4 & 91.0 & $18.1 \%$ & $10.2 \%$ \\
\hline NYSERDA 8 & 52.8 & 488.4 & 62.6 & 523.9 & 89.5 & 610.5 & 542.7 & 113.4 & 45.6 & $16.2 \%$ & $7.2 \%$ \\
\hline NYSERDA 9 & 251.6 & 482.6 & 272.5 & 527.8 & 426.5 & 603.3 & 536.3 & 229.5 & 162.4 & $22.3 \%$ & $16.9 \%$ \\
\hline NYSERDA 10 & 72.9 & 483.0 & 84.8 & 551.2 & 123.6 & 603.7 & 536.6 & 91.3 & 24.2 & $12.6 \%$ & $3.7 \%$ \\
\hline NYSERDA Avg & & & & & & & & $\mathbf{1 2 9 . 5}$ & 42.5 & $13.0 \%$ & $4.6 \%$ \\
\hline
\end{tabular}




\subsection{Measured Efficiencies}

Table 8 summarizes the monthly performances of the combi systems at the Nicor sites. Cumulative system efficiencies for the Nicor sites ranged from about $83 \%$ to $88 \%$. Table 9 summarizes the monthly performances of the combi systems at the NYSERDA sites. Cumulative system efficiencies for NYSERDA non-solar assisted sites ranged from about $77 \%$ to $93 \%$ for the forced-air systems.

SH systems including boilers and furnaces are negatively impacted by low SH load scenarios such as warm-climate applications and heating during shoulder months in cold climates. The negative impact is primarily because cycling losses and any standby losses become a high fraction of the total thermal load and degrade overall efficiencies. By plotting the seasonal combi efficiencies of the pilot sites as shown in Figure 5, it can be seen that combis also suffer from cycling and standby losses. The pilot site data indicate a general trend toward lower efficiencies in the summer and shoulder months than winter months. Though, DHW usage may help to dampen the seasonal efficiency swings.

Exacerbating the problem is the tendency for contractors to size combi systems based on DHW loads. To satisfy market demand for unlimited DHW, contractors may choose the highest capacity tankless water heater available. However, despite manufacturer-claimed turndowns of up to 10:1 (in terms of burner capacity), the results shown in Figure 5 indicate compromised performance during some low SH load scenarios.

Table 8. Nicor Combi System Monthly Performance Data

\begin{tabular}{c|c|c|c|c|c}
\hline Month & $\mathbf{1}$ & $\mathbf{2}$ & $\mathbf{3}$ & $\mathbf{4}$ & $\mathbf{5}$ \\
\hline January 2013 & $83.5 \%$ & $87.1 \%$ & - & - & - \\
\hline February 2013 & $82.5 \%$ & $87.1 \%$ & - & - & - \\
March 2013 & $82.5 \%$ & $87.6 \%$ & - & - & - \\
April 2013 & $82.0 \%$ & $87.9 \%$ & - & - & - \\
May 2013 & $80.5 \%$ & $88.8 \%$ & - & - & - \\
\hline June 2013 & $73.6 \%$ & $87.4 \%$ & $87.4 \%$ & - & - \\
July 2013 & $74.7 \%$ & $85.9 \%$ & $88.0 \%$ & - & - \\
\hline August 2013 & $72.7 \%$ & $85.8 \%$ & $86.5 \%$ & - & - \\
September 2013 & $77.6 \%$ & $86.6 \%$ & $83.9 \%$ & - & - \\
October 2013 & $83.5 \%$ & $89.8 \%$ & $82.3 \%$ & $86.0 \%$ & $83.1 \%$ \\
November 2013 & $84.8 \%$ & $90.0 \%$ & $84.6 \%$ & - & $86.8 \%$ \\
\hline December 2013 & - & $88.4 \%$ & $85.1 \%$ & $81.7 \%$ & $84.2 \%$ \\
January 2014 & - & $87.9 \%$ & $88.7 \%$ & $86.3 \%$ & $78.6 \%$ \\
\hline February 2014 & - & - & $85.0 \%$ & $84.8 \%$ & $83.3 \%$ \\
\hline March 2014 & - & - & $84.9 \%$ & - & $82.2 \%$ \\
\hline April 2014 & - & - & $84.1 \%$ & - & $81.3 \%$ \\
Cumulative & $82.8 \%$ & $88.0 \%$ & $86.4 \%$ & $85.6 \%$ & $82.8 \%$ \\
\hline
\end{tabular}


Table 9. NYSERDA Combi System Monthly Performance Data

\begin{tabular}{c|c|c|c|c|c|c|c|c|c|c|}
\hline Month & 1-G & 2-A & 3-A & 4-B & 5-C & 6-B & 7-D & 8-E & 9-F & 10-A \\
\hline January 2013 & - & $76.9 \%$ & - & $83.7 \%$ & - & $82.6 \%$ & $90.3 \%$ & - & - & - \\
\hline February 2013 & - & $78.8 \%$ & - & $82.6 \%$ & - & $83.4 \%$ & $90.3 \%$ & - & - & - \\
\hline March 2013 & - & $78.5 \%$ & - & $82.6 \%$ & - & $83.6 \%$ & $91.1 \%$ & - & - & - \\
\hline April 2013 & - & $77.3 \%$ & $91.1 \%$ & $81.2 \%$ & $77.2 \%$ & $83.5 \%$ & $91.5 \%$ & - & $95.2 \%$ & $91.4 \%$ \\
\hline May 2013 & - & $73.5 \%$ & $91.8 \%$ & $76.6 \%$ & $74.0 \%$ & $82.3 \%$ & $86.7 \%$ & - & $95.5 \%$ & $89.0 \%$ \\
\hline June 2013 & - & $69.4 \%$ & $92.2 \%$ & $70.5 \%$ & $68.2 \%$ & $80.8 \%$ & $87.8 \%$ & - & $94.5 \%$ & $83.9 \%$ \\
\hline July 2013 & - & $67.4 \%$ & $86.5 \%$ & $68.3 \%$ & $60.7 \%$ & $80.9 \%$ & $85.1 \%$ & - & $94.5 \%$ & $80.4 \%$ \\
\hline August 2013 & $96.0 \%$ & $63.0 \%$ & $85.3 \%$ & $68.3 \%$ & $64.7 \%$ & - & $77.4 \%$ & - & $92.7 \%$ & $79.5 \%$ \\
\hline September 2013 & $82.1 \%$ & $71.6 \%$ & $88.9 \%$ & $71.5 \%$ & $68.0 \%$ & - & $79.4 \%$ & - & $91.8 \%$ & $78.3 \%$ \\
\hline October 2013 & $67.1 \%$ & $74.6 \%$ & $91.0 \%$ & $80.3 \%$ & $75.0 \%$ & $82.3 \%$ & $87.1 \%$ & $94.0 \%$ & $90.9 \%$ & $87.4 \%$ \\
\hline November 2013 & $73.1 \%$ & $78.2 \%$ & $93.1 \%$ & $84.0 \%$ & $76.2 \%$ & $82.1 \%$ & $97.9 \%$ & $92.7 \%$ & $90.9 \%$ & $90.6 \%$ \\
\hline December 2013 & $68.1 \%$ & $79.3 \%$ & $93.4 \%$ & $84.2 \%$ & $74.1 \%$ & $81.2 \%$ & $98.9 \%$ & $92.4 \%$ & $91.6 \%$ & $90.4 \%$ \\
\hline January 2014 & $72.4 \%$ & $83.2 \%$ & $90.9 \%$ & $81.7 \%$ & $71.8 \%$ & $76.8 \%$ & - & $93.9 \%$ & $91.4 \%$ & $87.3 \%$ \\
\hline February 2014 & $69 \%$ & - & $91.7 \%$ & - & $60.7 \%$ & $83.8 \%$ & - & $93.3 \%$ & $90.9 \%$ & $85.6 \%$ \\
March 2014 & $73.0 \%$ & - & $92.1 \%$ & - & & $83.8 \%$ & - & $91.0 \%$ & $90.6 \%$ & $85.2 \%$ \\
\hline April 2014 & $87.2 \%$ & - & - & - & - & - & - & $89.4 \%$ & - & - \\
Cumulative & - & - & - & - & - & - & - & $74.4 \%$ & - & - \\
\hline January 2013 & $74.4 \%$ & $77.3 \%$ & $90.3 \%$ & $82.0 \%$ & $72.0 \%$ & $82.4 \%$ & $92.2 \%$ & $93.0 \%$ & $91.7 \%$ & $87.4 \%$ \\
\hline
\end{tabular}




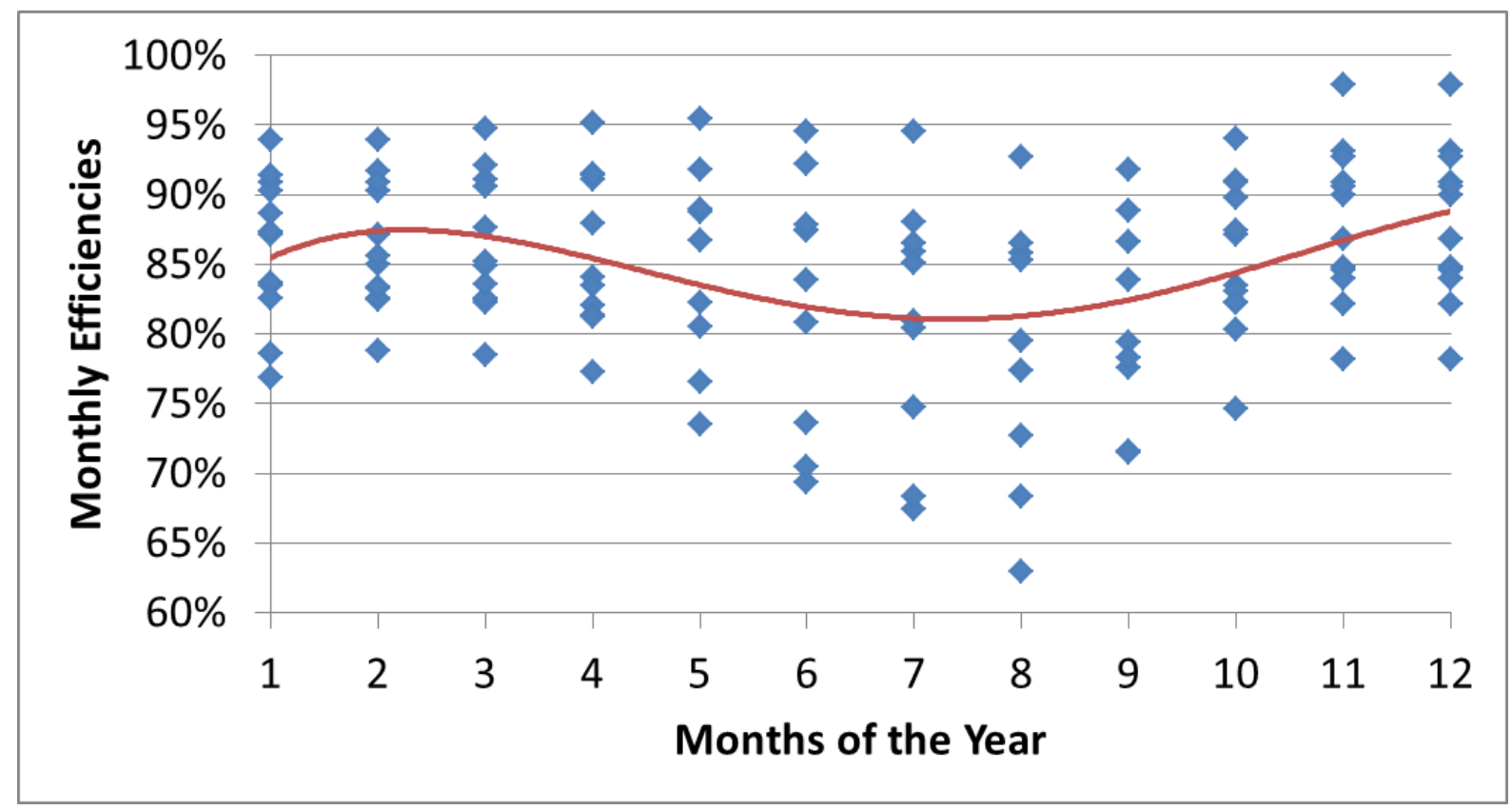

Figure 5. Seasonality of efficiencies

The following 13 tables (Tables 10-22) show the average daily DHW, SH, and total loads for each month of each field test along with the monthly cumulative efficiencies. Additionally, the tables show the percentage of time during each month that hot circulated water returned from the AHU to the water heater at $105^{\circ} \mathrm{F}$ or lower. The return water temperature is significant because NorthernSTAR's laboratory work found that the highest combi system efficiencies were achieved by minimizing the water temperatures returning from the hydronic AHU. The NorthernSTAR team set the maximum threshold for achieving condensing operation at $105^{\circ} \mathrm{F}$ AHU return water (Schoenbauer 2012).

Below each site table (Tables 10-22) there are two plots; one showing daily efficiency calculations versus average daily loads; and the other showing daily efficiency calculations versus AHU return water to the tankless water heater.

The homeowners for the following five Nicor sites were HVAC contractor and Nicor trade allies. During training, they were asked to keep the AHU return water temperatures to a minimum while maintaining comfortable supply air for the systems they installed in their homes. All of them, during the demonstration period, maintained AHU return water temperatures near $105^{\circ} \mathrm{F}$ for some time and higher temperatures at other times.

\subsubsection{Nicor Site 1 Performance Summary}

The Nicor Site 1 home was purchased shortly before the combi system was installed and therefore previous utility bills were unavailable. This site, along with the following four Nicor sites, was retrofit with System B, an integrated pre-engineered packaged combi system with a $199 \mathrm{kBtu} / \mathrm{h}$ input tankless water heater. During the combi system installation for Nicor Site 1, the 
contractor found difficulties with the AHU blower and DHW priority flow sensor. Together with the manufacturer, the contractor resolved the installation issues. While the issues were found to be installation errors, the manufacturer made changes to its product in an effort to avoid future problems.

The homeowner for Site 1 kept the water heater temperature set point at a level that maintained AHU return water slightly above $105^{\circ} \mathrm{F}$ most of the time. As a result, delivered air from the AHU was supplied at only about $95^{\circ} \mathrm{F}$. Relative to other host sites in this study, the DHW and SH loads were very low. As such, this home may have been a good candidate for a smaller condensing tankless water heater.

Despite maintaining AHU return water around $105^{\circ} \mathrm{F}$ (Figure 7), efficiencies for this site were in the range of non-condensing operation. Low DHW and SH loads may have been a contributing factor to the low efficiencies as Figure 6 indicates significant low-load operation at efficiencies below $70 \%$.

Table 10. Nicor Site 1 Average Daily Loads Versus Performance by Month

\begin{tabular}{c|c|c|c|c|c}
\hline \multicolumn{5}{|c}{ Nicor Site 1 } \\
\hline Month & $\begin{array}{c}\text { Avg. DHW } \\
\text { (Btu) }\end{array}$ & $\begin{array}{c}\text { Avg. AHU } \\
\text { (Btu) }\end{array}$ & $\begin{array}{c}\text { Total Load } \\
\text { (Btu) }\end{array}$ & $\mathbf{\%}<\mathbf{1 0 5}$ F & Efficiency \\
\hline January 2013 & 24,975 & 483,585 & 508,560 & $63.3 \%$ & $83.5 \%$ \\
\hline February 2013 & 30,142 & 532,590 & 562,732 & $31.7 \%$ & $82.5 \%$ \\
March 2013 & 25,204 & 396,311 & 421,515 & $89.9 \%$ & $82.5 \%$ \\
\hline April 2013 & 16,858 & 141,296 & 158,154 & $70.8 \%$ & $82.0 \%$ \\
May 2013 & 13,710 & 3,943 & 17,653 & $40.7 \%$ & $80.5 \%$ \\
June 2013 & 13,112 & 2,760 & 15,872 & $37.6 \%$ & $73.6 \%$ \\
July 2013 & 13,710 & 3,944 & 17,654 & $28.1 \%$ & $74.7 \%$ \\
August 2013 & 11,993 & 2,224 & 14,217 & $37.4 \%$ & $72.7 \%$ \\
September 2013 & 10,453 & 11,245 & 21,698 & $32.1 \%$ & $77.6 \%$ \\
\hline October 2013 & 14,064 & 150,463 & 164,527 & $26.7 \%$ & $83.5 \%$ \\
\hline November 2013 & 27,401 & 308,459 & 335,860 & $57.1 \%$ & $84.8 \%$ \\
\hline
\end{tabular}

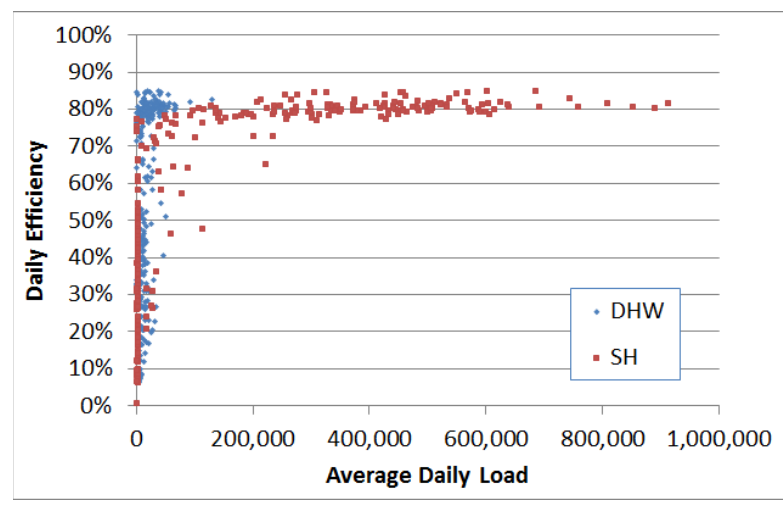

Figure 6. Nicor 1 daily efficiencies versus average daily loads

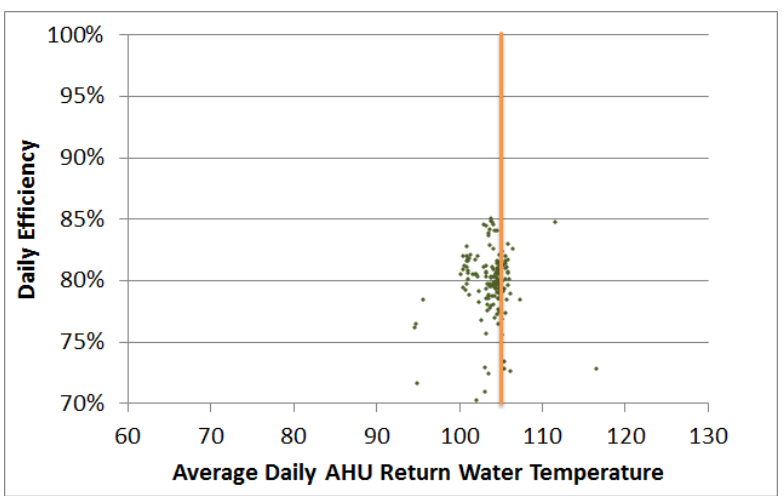

Figure 7. Nicor 1 daily efficiencies versus average AHU return water temperatures 


\subsubsection{Nicor Site 2 Performance Summary}

At reportedly 4,500 $\mathrm{ft}^{2}$, the home for Nicor Site 2 was much bigger than site 1, which was only about $1,800 \mathrm{ft}^{2}$. As such, the DHW and SH loads were much larger. The existing furnace that was replaced for Nicor Site 2 was old, but the existing water heater was a fairly new noncondensing tankless water heater.

From January to April of 2013, the AHU return water was about $110^{\circ} \mathrm{F}$ with supply air at about $110^{\circ} \mathrm{F}$ as well. Upon request, the homeowner reduced the water heater set point for the following winter. From September to November 2013, the AHU return water was about $100^{\circ} \mathrm{F}$ with supply air at about $100^{\circ} \mathrm{F}$ as well. In December 2013 data indicate an increase in the AHU return water to about $105^{\circ} \mathrm{F}$ and then in January 2014 another increase back up close to $110^{\circ} \mathrm{F}$. Supply air temperatures for December and January were about $105^{\circ} \mathrm{F}$ and $115^{\circ} \mathrm{F}$, respectively. Data in Table 11 seem to indicate increases and decreases in efficiencies corresponding to decreases and increases in AHU return water temperature from September 2013 through January 2014.

Figure 9 shows a separation in data points where AHU return water was above $105^{\circ} \mathrm{F}$ and daily efficiencies were nearly all less than $90 \%$. When AHU return water was below $105^{\circ} \mathrm{F}$, the efficiencies approached $90 \%$ and were often higher.

Table 11. Nicor Site 2 Average Daily Loads Versus Performance by Month

\begin{tabular}{c|c|c|c|c|c}
\hline \multicolumn{7}{|c}{ Nicor Site 2 } \\
\hline Month & $\begin{array}{c}\text { Avg. DHW } \\
\text { (Btu) }\end{array}$ & $\begin{array}{c}\text { Avg. AHU } \\
\text { (Btu) }\end{array}$ & $\begin{array}{c}\text { Total Load } \\
(\mathbf{B t u})\end{array}$ & $\mathbf{\%}<\mathbf{1 0 5}$ F & Efficiency \\
\hline January 2013 & 38,252 & 701,243 & 739,495 & $7.5 \%$ & $87.1 \%$ \\
\hline February 2013 & 42,097 & 728,700 & 770,797 & $12.5 \%$ & $87.1 \%$ \\
\hline March 2013 & 41,006 & 628,921 & 669,927 & $13.5 \%$ & $87.6 \%$ \\
\hline April 2013 & 29,097 & 357,710 & 386,807 & $32.0 \%$ & $87.9 \%$ \\
May 2013 & 14,372 & 22,741 & 37,113 & $97.3 \%$ & $88.8 \%$ \\
\hline June 2013 & 35,933 & 27,605 & 63,538 & $87.8 \%$ & $87.4 \%$ \\
July 2013 & 34,813 & 6,351 & 41,164 & $56.1 \%$ & $85.9 \%$ \\
\hline August 2013 & 35,354 & 4,631 & 39,985 & $47.8 \%$ & $85.8 \%$ \\
\hline September 2013 & 25,319 & 25,482 & 50,801 & $87.7 \%$ & $86.6 \%$ \\
\hline October 2013 & 35,943 & 220,909 & 256,852 & $99.3 \%$ & $89.8 \%$ \\
\hline November 2013 & 40,027 & 493,358 & 533,385 & $97.1 \%$ & $90.0 \%$ \\
\hline December 2013 & 36,967 & 714,155 & 751,122 & $94.9 \%$ & $88.4 \%$ \\
January 2014 & 38,798 & $1,016,461$ & $1,055,259$ & $23.3 \%$ & $87.9 \%$ \\
\hline
\end{tabular}




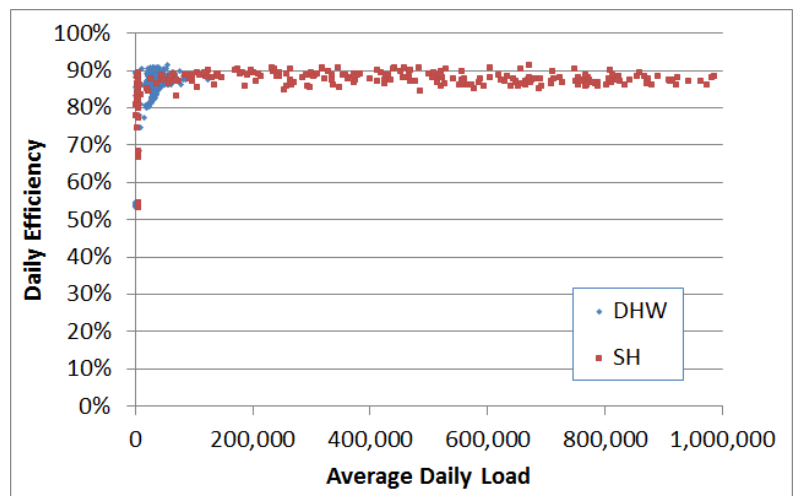

Figure 8. Nicor 2 daily efficiencies versus average daily loads

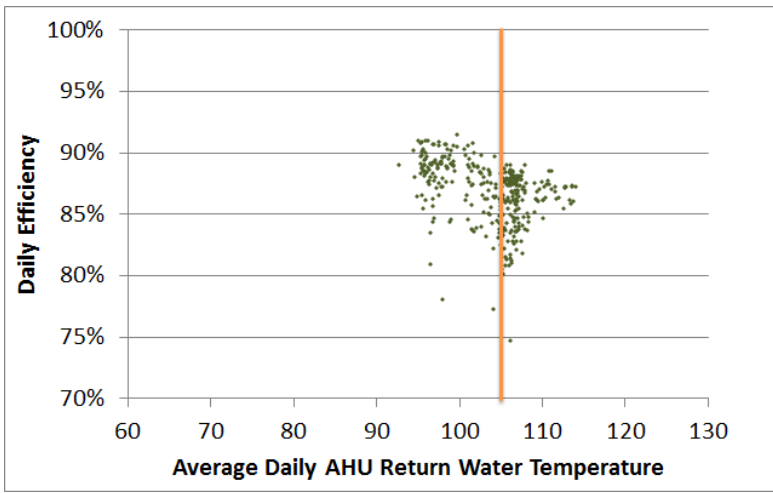

Figure 9. Nicor 2 daily efficiencies versus average AHU return water temperatures

\subsubsection{Nicor Site 3 Performance Summary}

For the first few cold months of Nicor 3 operation, AHU return water was about $105^{\circ}-110^{\circ} \mathrm{F}$ with similar supply air temperatures. In December 2013, data indicate the homeowner made changes that increased the AHU return water temperature to about $115^{\circ} \mathrm{F}$. However, changes in efficiencies corresponding to the change in return water temperature are not apparent.

Similar to Nicor Site 1, Figure 10 shows that there are significant data points at low-load operation where efficiencies were below $70 \%$.

Table 12. Nicor Site 3 Average Daily Loads Versus Performance by Month

\begin{tabular}{|c|c|c|c|c|c|}
\hline \multicolumn{6}{|c|}{ Nicor Site 3} \\
\hline Month & $\begin{array}{l}\text { Avg. DHW } \\
\text { (Btu) }\end{array}$ & $\begin{array}{c}\text { Avg. AHU } \\
\text { (Btu) }\end{array}$ & $\begin{array}{l}\text { Total Load } \\
\text { (Btu) }\end{array}$ & $\%<105^{\circ} \mathrm{F}$ & Efficiency \\
\hline June 2013 & 45,158 & 3,479 & 48,637 & $30.6 \%$ & $87.4 \%$ \\
\hline July 2013 & 50,098 & 3,897 & 53,995 & $43.0 \%$ & $88.0 \%$ \\
\hline August 2013 & 46,448 & 2,204 & 48,652 & $48.4 \%$ & $86.5 \%$ \\
\hline September 2013 & 41,336 & 13,835 & 55,171 & $16.6 \%$ & $83.9 \%$ \\
\hline October 2013 & 38,515 & 109,917 & 148,432 & $7.1 \%$ & $82.3 \%$ \\
\hline November 2013 & 50,580 & 315,079 & 365,659 & $3.7 \%$ & $84.6 \%$ \\
\hline December 2013 & 55,884 & 497,578 & 553,462 & $5.7 \%$ & $85.1 \%$ \\
\hline January 2014 & 56,545 & 583,087 & 639,632 & $0.9 \%$ & $88.7 \%$ \\
\hline February 2014 & 64,755 & 583,535 & 648,290 & $0.9 \%$ & $85.0 \%$ \\
\hline March 2014 & 64,438 & 387,172 & 451,610 & $3.2 \%$ & $84.9 \%$ \\
\hline April 2014 & 59,470 & 167,203 & 226,673 & $4.0 \%$ & $84.1 \%$ \\
\hline
\end{tabular}




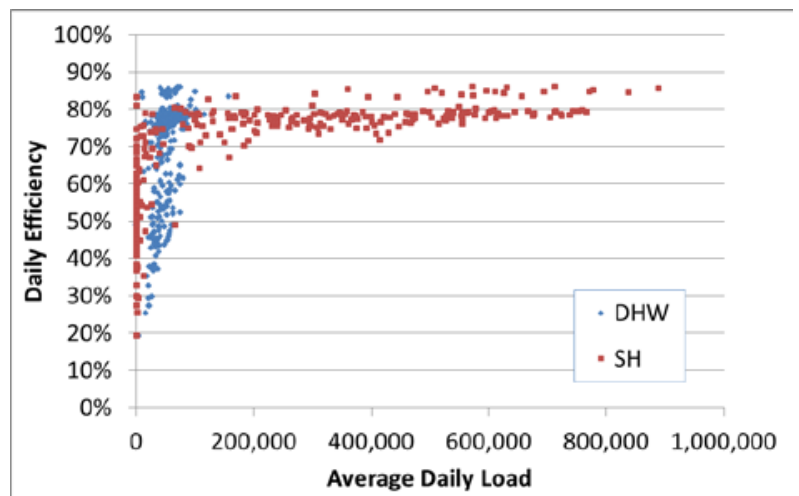

Figure 10. Nicor 3 daily efficiencies versus average daily loads

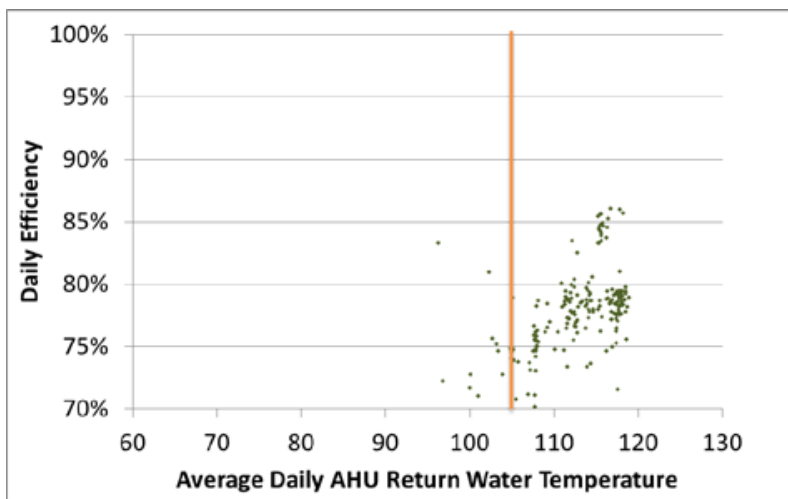

Figure 11. Nicor 3 daily efficiencies versus average AHU return water temperatures

\subsubsection{Nicor Site 4 Performance Summary}

Nicor Site 4 is a commercial space that houses a Heating and Cooling contractor. This site has a $500-\mathrm{ft}^{2}$ front office with 18 - $\mathrm{ft}$ ceilings, and a $1200-\mathrm{ft}^{2}$ back office with $24-\mathrm{ft}$ ceilings. The purpose of this installation was to provide the HVAC contractor with a showcase system for their customers as well as an opportunity to become familiar with the technology.

Multiple space conditioning systems are installed at this site at any given time to demonstrate operation to potential customers. As Table 13 indicates, there was no DHW consumption.

The contractor planned to connect this system to an apartment above the shop, but the water runs were determined to be too long. Instead, the shop owner used the combi system to provide $\mathrm{SH}$ for the shop.

Table 13. Nicor Site 4 Average Daily Loads Versus Performance by Month

\begin{tabular}{c|c|c|c|c|c}
\hline \multicolumn{7}{c}{ Nicor Site 4 } \\
\hline Month & $\begin{array}{c}\text { Avg. DHW } \\
\text { (Btu) }\end{array}$ & $\begin{array}{c}\text { Avg. AHU } \\
\text { (Btu) }\end{array}$ & $\begin{array}{c}\text { Total Load } \\
\text { (Btu) }\end{array}$ & $\mathbf{\%}<\mathbf{1 0 5}^{\circ} \mathbf{F}$ & Efficiency \\
\hline December 2013 & 0 & 52,042 & 52,042 & $94.8 \%$ & $81.7 \%$ \\
January 2014 & 0 & 268,651 & 268,651 & $99.4 \%$ & $86.3 \%$ \\
February 2014 & 0 & 71,557 & 71,557 & $96.8 \%$ & $84.8 \%$ \\
March 2014 & 0 & 71,557 & 71,557 & $96.8 \%$ & $84.8 \%$ \\
\hline
\end{tabular}




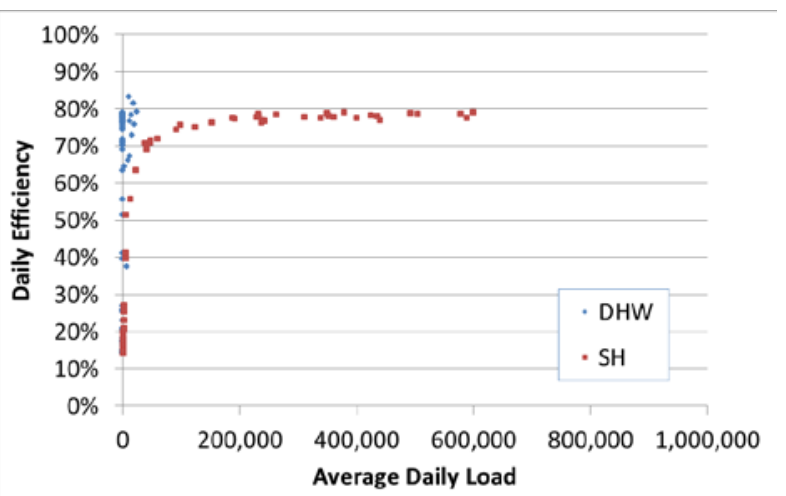

Figure 12. Nicor 4 daily efficiencies versus average daily loads

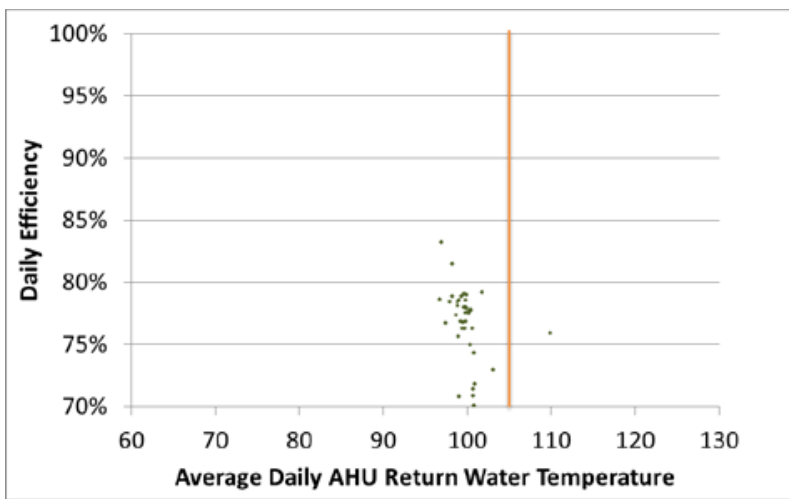

Figure 13. Nicor 4 daily efficiencies versus average AHU return water temperatures

\subsubsection{Nicor Site 5 Performance Summary}

The combi system for Nicor Site 5 provided heat to only one zone (first floor) of the home. The second zone for the second and third floors of the home was heated with a traditional forced-air furnace. The combi system was installed shortly after the house was purchased. Therefore, no utility bills were available for analysis.

In October 2013, the homeowner maintained AHU return water at about $120^{\circ} \mathrm{F}$. In November 2013, the homeowner made adjusts to the system such that AHU return water temperature dropped to about $95^{\circ} \mathrm{F}$ for about a month and a half. About midway through December 2013, the system was adjusted again to maintain return water back up to about $120^{\circ} \mathrm{F}$. A corresponding increase in efficiency can be seen in Table 14 for November and December when the AHU return water was reduced. However, during that time, data indicate the average supply air temperature dropped to about $100^{\circ} \mathrm{F}$.

Figure 15 shows the separation of data points where AHU return water was about $120^{\circ} \mathrm{F}$ and then $95^{\circ} \mathrm{F}$. However, the data does not indicate significant efficiency improvements with the drop in return water temperature. Moreover, the SH loads were relatively high as the system supplied heating for one zone in a large home.

Table 14. Nicor Site 5 Average Daily Loads Versus Performance by Month

\begin{tabular}{|c|c|c|c|c|c|}
\hline \multicolumn{6}{|c|}{ Nicor Site 5} \\
\hline Month & $\begin{array}{l}\text { Avg. DHW } \\
\text { (Btu) }\end{array}$ & $\begin{array}{c}\text { Avg. AHU } \\
\text { (Btu) }\end{array}$ & $\begin{array}{l}\text { Total Load } \\
\text { (Btu) }\end{array}$ & $\%<105^{\circ} \mathrm{F}$ & Efficiency \\
\hline October 2013 & 52,831 & 278,287 & 331,118 & $21.3 \%$ & $83.1 \%$ \\
\hline November 2013 & 44,655 & 404,488 & 449,143 & $99.5 \%$ & $86.8 \%$ \\
\hline December 2013 & 47,299 & 615,424 & 662,723 & $64.6 \%$ & $84.2 \%$ \\
\hline January 2014 & 44,624 & 615,953 & 660,577 & $6.4 \%$ & $78.6 \%$ \\
\hline February 2014 & 40,816 & 623,682 & 664,498 & $4.4 \%$ & $83.3 \%$ \\
\hline March 2014 & 42,825 & 475,384 & 518,209 & $8.1 \%$ & $82.2 \%$ \\
\hline April 2014 & 48,947 & 232,756 & 281,703 & $9.3 \%$ & $81.3 \%$ \\
\hline
\end{tabular}




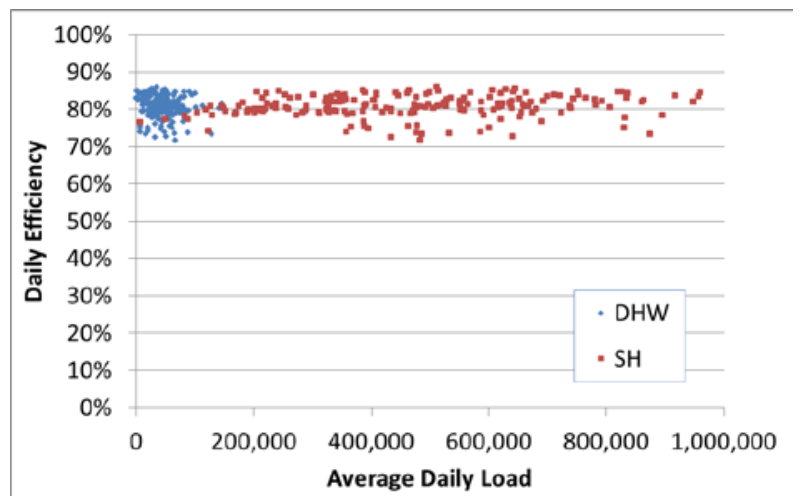

Figure 14. Nicor 5 daily efficiencies versus average daily loads

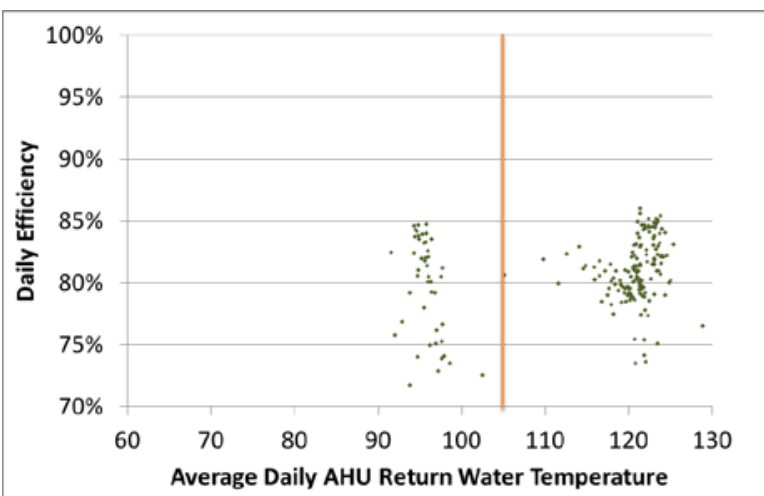

Figure 15. Nicor 5 daily efficiencies versus average AHU return water temperatures

\subsubsection{NYSERDA Site 2 Performance Summary}

NYSERDA Site 2 was retrofit with System A, an integrated pre-engineered packaged combi system with a $152 \mathrm{kBtu} / \mathrm{h}$ input tankless water heater. The installing contractor had to return to the site on one occasion to address a no-heat call. The cause for no heat was a blocked intake pipe from snow. DHW usage for this site was low relative to the other demonstration sites. Also, the contractor's load calculations for the home were about two times the design-day gas usage and estimated design-day capacity observed by GTI through billing analysis. Given the low DHW use and moderate SH loads (Figure 16), this home may have been a good candidate for a smaller condensing tankless water heater if one were available.

For NYSERDA Site 2, significant additional work and costs were cited by the contractor for special venting required by the manufacturer.

The water heater temperature set point for NYSERDA Site 2 was about $140^{\circ} \mathrm{F}$ and the AHU return water was generally about $110^{\circ} \mathrm{F}$ to $115^{\circ} \mathrm{F}$. AHU supply air was about $110^{\circ} \mathrm{F}$.

Table 15. NYSERDA Site 2 Average Daily Loads Versus Performance by Month

\begin{tabular}{c|c|c|c|c|c}
\hline \multicolumn{7}{c}{ NYSERDA Site 2 } \\
\hline Month & $\begin{array}{c}\text { Avg. DHW } \\
\text { (Btu) }\end{array}$ & $\begin{array}{c}\text { Avg. AHU } \\
\text { (Btu) }\end{array}$ & $\begin{array}{c}\text { Total Load } \\
\text { (Btu) }\end{array}$ & $\mathbf{\%}<\mathbf{1 0 5}$ F & Efficiency \\
\hline February 2013 & 15,887 & 333,887 & 349,774 & $15.8 \%$ & $78.8 \%$ \\
\hline March 2013 & 22,120 & 311,523 & 333,643 & $15.9 \%$ & $78.5 \%$ \\
\hline April 2013 & 17,594 & 190,530 & 208,124 & $15.7 \%$ & $77.3 \%$ \\
\hline May 2013 & 18,433 & 44,455 & 62,888 & $19.1 \%$ & $73.5 \%$ \\
\hline June 2013 & 19,060 & 12,838 & 31,899 & $25.2 \%$ & $69.4 \%$ \\
\hline July 2013 & 3,300 & 33,658 & 36,958 & $36.6 \%$ & $67.4 \%$ \\
August 2013 & 15,287 & 3,391 & 18,678 & $37.7 \%$ & $63.0 \%$ \\
\hline September 2013 & 13,975 & 38,749 & 52,724 & $20.1 \%$ & $71.6 \%$ \\
October 2013 & 14,533 & 107,460 & 121,993 & $18.1 \%$ & $74.6 \%$ \\
\hline November 2013 & 15,380 & 265,127 & 280,507 & $13.2 \%$ & $78.2 \%$ \\
\hline December 2013 & 18,441 & 335,689 & 354,129 & $11.7 \%$ & $79.3 \%$ \\
\hline February 2014 & 40,745 & 626,111 & 666,856 & $4.4 \%$ & $83.2 \%$ \\
\hline
\end{tabular}




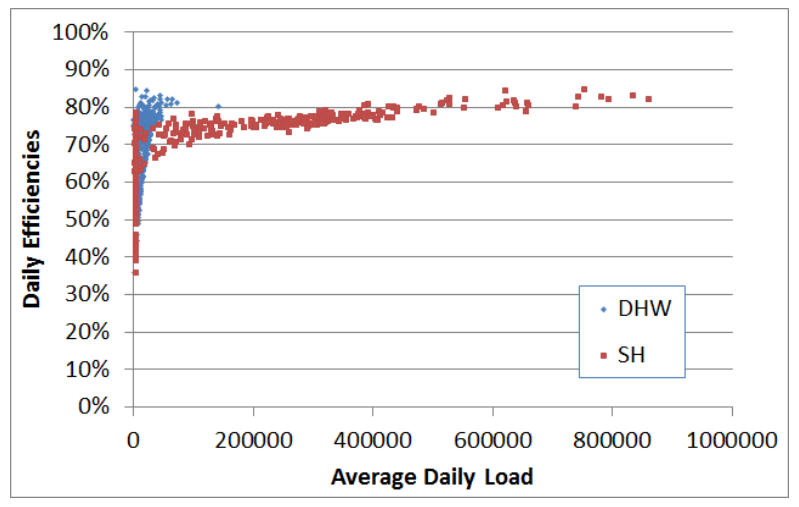

Figure 16. NYSERDA 2 daily efficiencies versus average daily loads

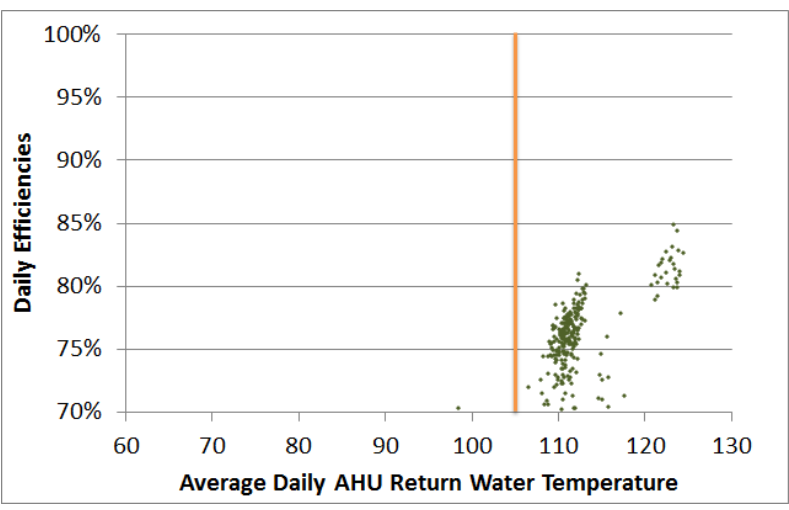

Figure 17. NYSERDA 2 daily efficiencies versus average AHU return water temperatures

\subsubsection{NYSERDA Site 3 Performance Summary}

NYSERDA Site 3 was also retrofit with System A, an integrated pre-engineered packaged combi system with a $152 \mathrm{kBtu} / \mathrm{h}$ input tankless water heater. During DAQ commissioning of Site 3 , the homeowners commented that they were getting cold and hot water sandwiches. The homeowners also commented that the system was meeting the SH load with no problems and they had no other issues. The same installing-contractor as NYSERDA Site 2 noted that this site also required significant additional work and costs for special venting required by the manufacturer.

The water heater temperature set point for NYSERDA Site 3 was about $140^{\circ} \mathrm{F}$ and the AHU return water was generally about $110^{\circ} \mathrm{F}$ to $115^{\circ} \mathrm{F}$. AHU supply air was about $115^{\circ} \mathrm{F}$. The system is the same packaged combi unit as Site 2, and the temperature set point and AHU return water temperatures for Sites 2 and 3 were similar. Yet, system performance was much better for Site 3 than for Site 2. A notable difference between the two sites was the fact that DHW loads for Site 2 were less than $30 \%$ of the DHW loads for Site 3 across 12 months.

Figure 19 indicates AHU return water was mostly above $105^{\circ} \mathrm{F}$. Yet, $90 \%+$ monthly cumulative efficiencies were achieved at this site.

Table 16. NYSERDA Site 3 Average Daily Loads Versus Performance by Month

\begin{tabular}{|c|c|c|c|c|c|}
\hline \multicolumn{6}{|c|}{ NYSERDA Site 3} \\
\hline Month & $\begin{array}{c}\text { Avg. DHW } \\
\text { (Btu) }\end{array}$ & $\begin{array}{c}\text { Avg. AHU } \\
\text { (Btu) }\end{array}$ & $\begin{array}{c}\text { Total Load } \\
\text { (Btu) }\end{array}$ & $\%<105^{\circ} \mathrm{F}$ & Efficiency \\
\hline April 2013 & 66,281 & 120,334 & 186,615 & $12.0 \%$ & $91.1 \%$ \\
\hline May 2013 & 77,171 & 37,027 & 114,198 & $14.5 \%$ & $91.8 \%$ \\
\hline June 2013 & 55,921 & 3,534 & 59,454 & $35.1 \%$ & $92.2 \%$ \\
\hline July 2013 & 27,547 & 33,084 & 60,631 & $35.8 \%$ & $86.5 \%$ \\
\hline August 2013 & 47,002 & 3,432 & 50,434 & $36.9 \%$ & $85.3 \%$ \\
\hline September 2013 & 47,013 & 12,970 & 59,983 & $24.1 \%$ & $88.9 \%$ \\
\hline October 2013 & 52,918 & 62,052 & 114,970 & $12.4 \%$ & $91.0 \%$ \\
\hline November 2013 & 66,988 & 228,590 & 295,578 & $10.7 \%$ & $93.1 \%$ \\
\hline
\end{tabular}




\begin{tabular}{c|c|c|c|c|c}
\hline \multicolumn{7}{c}{ NYSERDA Site 3 } \\
\hline Month & $\begin{array}{c}\text { Avg. DHW } \\
\text { (Btu) }\end{array}$ & $\begin{array}{c}\text { Avg. AHU } \\
\text { (Btu) }\end{array}$ & $\begin{array}{c}\text { Total Load } \\
\text { (Btu) }\end{array}$ & \% $<\mathbf{1 0 5}^{\circ} \mathbf{F}$ & Efficiency \\
\hline December 2013 & 80,114 & 340,305 & 420,419 & $9.0 \%$ & $93.4 \%$ \\
\hline January 2014 & 83,063 & 508,631 & 591,694 & $10.3 \%$ & $90.9 \%$ \\
February 2014 & 80,238 & 469,882 & 550,120 & $11.1 \%$ & $91.7 \%$ \\
\hline March 2014 & 74,662 & 391,000 & 465,662 & $11.4 \%$ & $92.1 \%$ \\
\hline
\end{tabular}

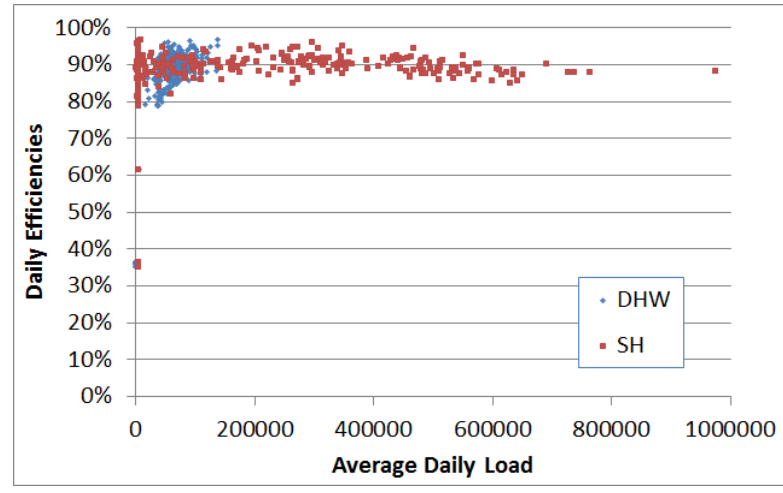

Figure 18. NYSERDA 3 daily efficiencies versus average daily loads

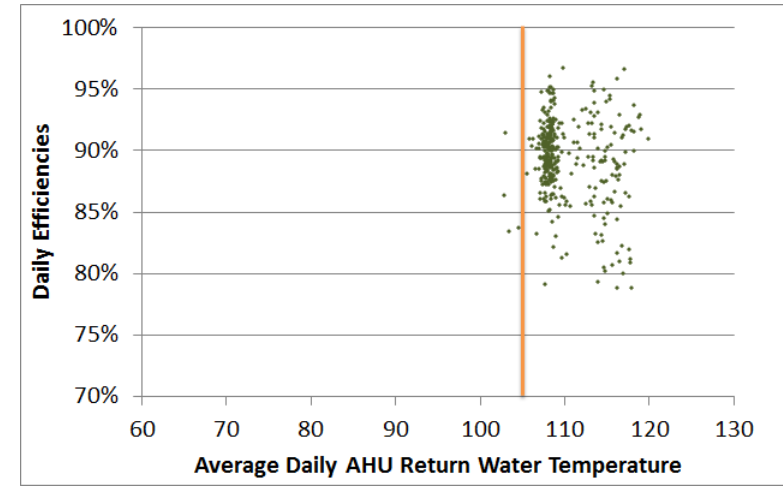

Figure 19. NYSERDA 3 daily efficiencies versus average AHU return water temperatures

\subsubsection{NYSERDA Site 4 Performance Summary}

NYSERDA Site 4 was retrofit with System B (same as Nicor sites), an integrated pre-engineered packaged combi system with a $199 \mathrm{kBtu} / \mathrm{h}$ input tankless water heater. The manufacturer for System B was different than System A. Prior to commissioning NYSERDA Site 4, the AHU developed a leak. An inspection by the installing-contractor found a defective weld in the hydronic heat exchanger coil. The contractor replaced the defective AHU with a new AHU that the manufacturer promptly provided.

The water heater temperature set point for NYSERDA Site 4 was about $160^{\circ} \mathrm{F}$. With $160^{\circ} \mathrm{F}$ water entering the $\mathrm{AHU}$, return water from the $\mathrm{AHU}$ was expected to be more than $110^{\circ} \mathrm{F}$ going back to the water heater. However, data in Figure 21 indicate AHU return water was consistently and significantly colder than $105^{\circ} \mathrm{F}$. Supply air was $110^{\circ} \mathrm{F}$ to $115^{\circ} \mathrm{F}$. The high temperature differential of about $60^{\circ} \mathrm{F}$ across the AHU water coil suggest that very high AHU air flow, very low AHU water flow, or a combination of the two were occurring. Performance results of this field test were unexpected because the AHU return water was consistently colder than $105^{\circ} \mathrm{F}$. Yet, efficiencies were in the low $80 \mathrm{~s}^{\circ} \mathrm{F}$ rather than low $90 \mathrm{~s}^{\circ} \mathrm{F}$, as would be expected for condensing operation. 
Table 17. NYSERDA Site 4 Average Daily Loads Versus Performance by Month

\begin{tabular}{c|c|c|c|c|c}
\hline \multicolumn{7}{|c}{ NYSERDA Site 4 } \\
\hline Month & $\begin{array}{c}\text { Avg. DHW } \\
\text { (Btu) }\end{array}$ & $\begin{array}{c}\text { Avg. AHU } \\
\text { (Btu) }\end{array}$ & $\begin{array}{c}\text { Total Load } \\
\text { (Btu) }\end{array}$ & $\begin{array}{c}\mathbf{\%}<\mathbf{1 0 5} \text { F } \\
\text { Efficiency }\end{array}$ \\
\hline February 2013 & 39,533 & 323,845 & 363,378 & $21.6 \%$ & $82.6 \%$ \\
March 2013 & 39,025 & 271,336 & 310,361 & $39.9 \%$ & $82.6 \%$ \\
\hline April 2013 & 36,721 & 136,339 & 173,060 & $78.7 \%$ & $81.2 \%$ \\
\hline May 2013 & 28,239 & 26,311 & 54,549 & $76.4 \%$ & $76.6 \%$ \\
\hline June 2013 & 20,165 & 7,983 & 28,147 & $83.9 \%$ & $70.5 \%$ \\
\hline July 2013 & 15,884 & 7,339 & 23,223 & $81.6 \%$ & $68.3 \%$ \\
August 2013 & 17,538 & 7,275 & 24,813 & $83.2 \%$ & $68.3 \%$ \\
\hline September 2013 & 19,144 & 14,048 & 33,192 & $86.1 \%$ & $71.5 \%$ \\
October 2013 & 23,576 & 70,763 & 94,339 & $96.5 \%$ & $80.3 \%$ \\
\hline November 2013 & 24,437 & 205,682 & 230,119 & $99.2 \%$ & $84.0 \%$ \\
\hline December 2013 & 29,730 & 299,799 & 329,529 & $99.2 \%$ & $84.2 \%$ \\
January 2014 & 32,207 & 401,933 & 434,140 & $99.6 \%$ & $81.7 \%$ \\
\hline
\end{tabular}

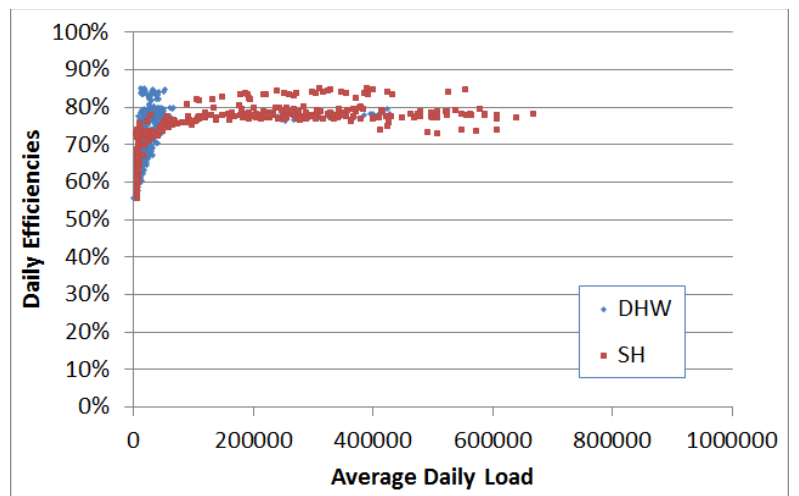

Figure 20. NYSERDA 4 daily efficiencies versus average daily loads

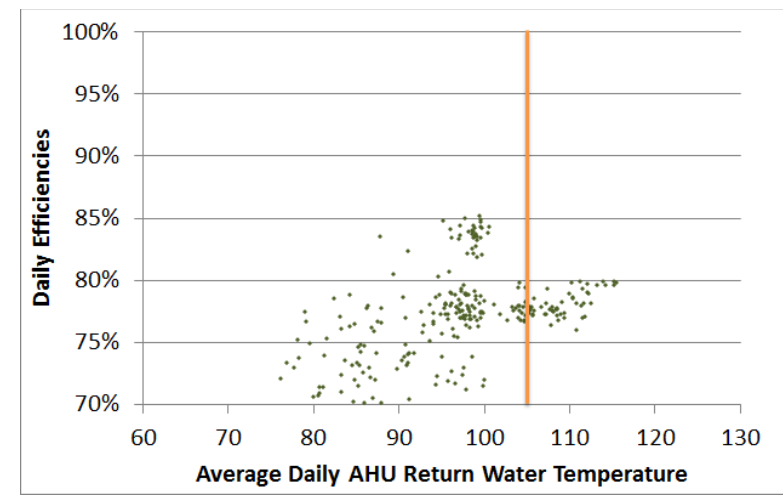

Figure 21. NYSERDA 4 daily efficiencies versus average AHU return water temperatures

\subsubsection{NYSERDA Site 6 Performance Summary}

NYSERDA Site 6 was also retrofit with System B, an integrated pre-engineered packaged combi system with a $199 \mathrm{kBtu} / \mathrm{h}$ input tankless water heater. In February 2014, data analysis indicated the likelihood of a leak in the system. The occupants of this home were renters and the water heater was located in a crawlspace under the house. Under those conditions, a steady slow leak could have gone unnoticed. The apparent leak skewed data for January 2014, so the dataset was eliminated from the overall analysis.

The water heater temperature set point for NYSERDA Site 6 was about $150^{\circ} \mathrm{F}$ and the AHU return water was generally about $110^{\circ} \mathrm{F}$ to $120^{\circ} \mathrm{F}$ (Figure 23). AHU supply air was about $110^{\circ} \mathrm{F}$. 
Table 18. NYSERDA Site 6 Average Daily Loads Versus Performance by Month

\begin{tabular}{c|c|c|c|c|c}
\hline \multicolumn{7}{|c}{ NYSERDA Site 6 } \\
\hline Month & $\begin{array}{c}\text { Avg. DHW } \\
\text { (Btu) }\end{array}$ & $\begin{array}{c}\text { Avg. AHU } \\
\text { (Btu) }\end{array}$ & $\begin{array}{c}\text { Total Load } \\
\text { (Btu) }\end{array}$ & \% $<$ 105 $\mathbf{F}$ & Efficiency \\
\hline January 2013 & 70,919 & 716,309 & 787,228 & $8.4 \%$ & $82.6 \%$ \\
\hline February 2013 & 5,315 & 524,658 & 529,973 & $18.3 \%$ & $83.4 \%$ \\
\hline March 2013 & 68,581 & 797,016 & 865,597 & $4.1 \%$ & $83.6 \%$ \\
\hline April 2013 & 54,368 & 419,908 & 474,276 & $7.0 \%$ & $83.5 \%$ \\
May 2013 & 40,153 & 99,983 & 140,136 & $15.2 \%$ & $82.3 \%$ \\
\hline June 2013 & 44,465 & 12,452 & 56,917 & $58.1 \%$ & $80.8 \%$ \\
July 2013 & 55,569 & 4,428 & 59,997 & $72.5 \%$ & $80.9 \%$ \\
\hline October 2013 & 62,726 & 458,917 & 521,643 & $9.4 \%$ & $82.3 \%$ \\
\hline November 2013 & 57,646 & 563,458 & 621,104 & $8.0 \%$ & $82.1 \%$ \\
\hline December 2013 & 62,830 & 767,876 & 830,706 & $8.9 \%$ & $81.2 \%$ \\
\hline January 2014 & 86,158 & 991,344 & $1,077,502$ & $7.7 \%$ & $76.8 \%$ \\
\hline
\end{tabular}

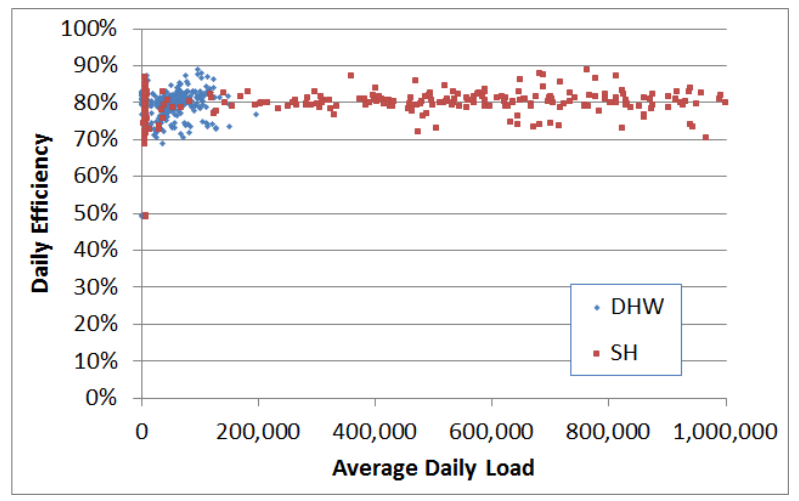

Figure 22. NYSERDA 6 daily efficiencies versus average daily loads

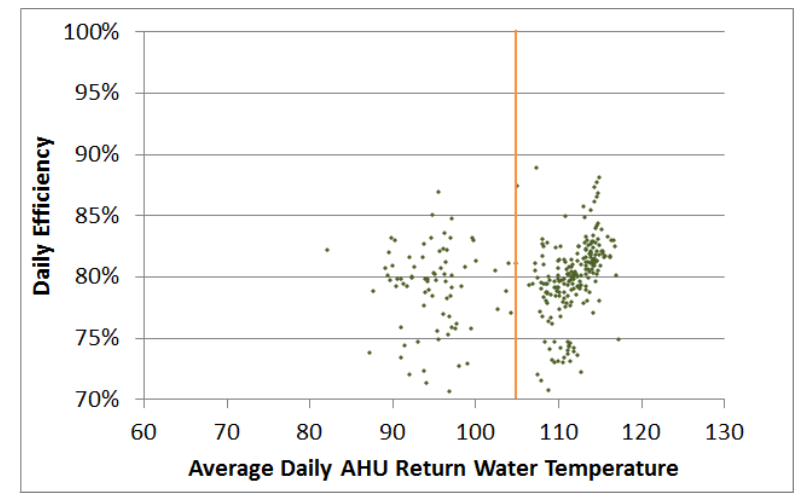

Figure 23. NYSERDA 6 daily efficiencies versus average AHU return water temperatures

\subsubsection{NYSERDA Site 7 Performance Summary}

NYSERDA Site 7 was retrofit with System D, which consisted of a tankless water heater and a third party AHU. The water heater used for the combi system was designed to heat water only to the extent needed. Unlike other well-known tankless water heaters, this water heater does not overheat water first with subsequent quenching to maintain set point. The AHU used for this system was specifically designed with condensing combi system applications in mind.

Between January 2013 and May 2013 the water heater temperature set point was about $175^{\circ} \mathrm{F}$ and the AHU return water was about $125^{\circ} \mathrm{F}$. In October 2013, the temperature set point was adjusted down to about $135^{\circ} \mathrm{F}$ to $140^{\circ} \mathrm{F}$. AHU return water dropped to a about $105^{\circ} \mathrm{F}$ and $\mathrm{AHU}$ supply air was delivered at about $105^{\circ} \mathrm{F}$ as well. Even with the high set point temperature of $175^{\circ} \mathrm{F}$, this system performed well with $90 \%+$ efficiencies. However, when the set point temperature was dropped in October the efficiencies appear to go up correspondingly. The change in set point temperature is likely the reason for the bifurcated SH data shown in Figure 24 at high loads. 
Figure 25 shows a dichotomy in data points and clear trend in higher efficiencies as AHU return water was reduced from $120^{\circ} \mathrm{F}+$ to about $105^{\circ} \mathrm{F}$.

Table 19. NYSERDA Site 7 Average Daily Loads Versus Performance by Month

\begin{tabular}{c|c|c|c|c|c}
\hline \multicolumn{7}{|c}{ NYSERDA Site 7 } \\
\hline Month & $\begin{array}{c}\text { Avg. DHW } \\
\text { (Btu) }\end{array}$ & $\begin{array}{c}\text { Avg. AHU } \\
\text { (Btu) }\end{array}$ & $\begin{array}{c}\text { Total Load } \\
\text { (Btu) }\end{array}$ & \% $<$ 105 $\mathbf{F}$ & Efficiency \\
\hline January 2013 & 27,418 & 314,545 & 341,963 & $4.8 \%$ & $90.3 \%$ \\
\hline February 2013 & 31,973 & 442,885 & 474,858 & $4.3 \%$ & $90.3 \%$ \\
\hline March 2013 & 50,905 & 337,752 & 388,657 & $6.2 \%$ & $91.1 \%$ \\
\hline April 2013 & 46,525 & 141,102 & 187,627 & $7.6 \%$ & $91.5 \%$ \\
\hline May 2013 & 26,544 & 20,575 & 47,119 & $5.1 \%$ & $86.7 \%$ \\
\hline June 2013 & 32,909 & 0 & 32,909 & $100.0 \%$ & $87.8 \%$ \\
July 2013 & 19,609 & 0 & 19,609 & $100.0 \%$ & $85.1 \%$ \\
\hline August 2013 & 24,201 & 108 & 24,309 & $52.3 \%$ & $77.4 \%$ \\
\hline September 2013 & 30,973 & 15,110 & 46,083 & $8.2 \%$ & $79.4 \%$ \\
\hline October 2013 & 31,537 & 67,229 & 98,766 & $10.4 \%$ & $87.1 \%$ \\
\hline November 2013 & 32,906 & 281,353 & 314,259 & $7.3 \%$ & $97.9 \%$ \\
\hline December 2013 & 47,809 & 388,918 & 436,727 & $9.0 \%$ & $98.9 \%$ \\
\hline
\end{tabular}

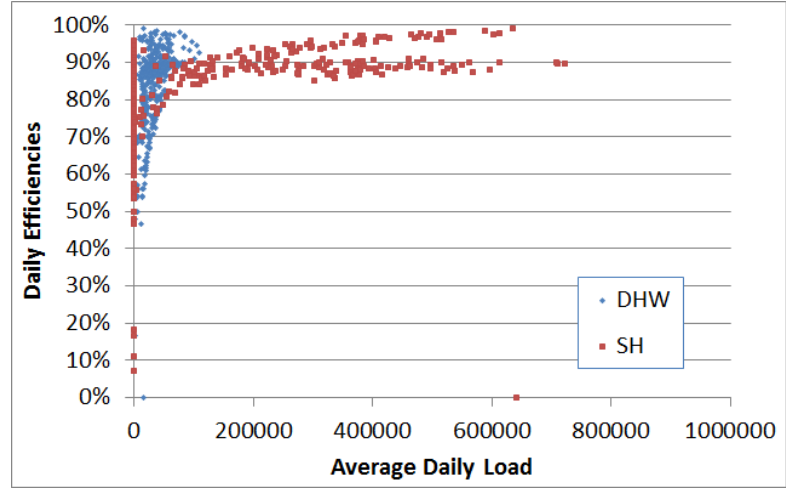

Figure 24. NYSERDA 7 daily efficiencies versus average daily loads

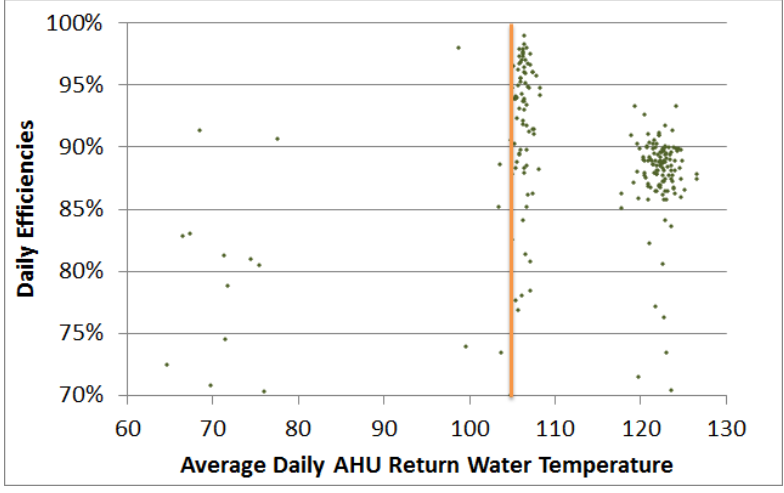

Figure 25. NYSERDA 7 daily efficiencies versus average AHU return water temperatures

\subsubsection{NYSERDA Site 8 Performance Summary}

NYSERDA Site 8 was retrofit with System E, which consisted of a tankless water heater and a third-party AHU. The tankless water heater for this site has an integral 2-gallon storage tank. The AHU for this site was from a different manufacturer than the one for Site 7. However, like the AHU for Site 7, the AHU for Site 8 was specifically designed with condensing combi system applications in mind.

At DAQ commissioning, the homeowner indicated that while the Combi system kept the house adequately warm, at times only warm water was being provided - not hot. The homeowner noted the warm-water occurrences seemed to be coincidental with stopping and restarting of water flow. Also, in early February 2014, the homeowner witnessed the burner flame attempt to restart 
and then go out approximately three times followed by an error code indicating "poor flame check gas line, electrical power, and connections." The homeowner inspected the gas, power, condensate pump, and air intake and exhaust and all appear to be functioning properly. The tankless water heater manufacturer technician inspected the heat exchanger and recommended a water heater replacement. The water heater was subsequently replaced in February.

Between October 2013 and December 2013 the water heater temperature set point was about $140^{\circ} \mathrm{F}$ and the AHU return water was about $105^{\circ} \mathrm{F}$. In January 2014 , the temperature set point was adjusted down to about $120^{\circ} \mathrm{F}$. AHU return water dropped to about $95^{\circ} \mathrm{F}$ and AHU supply air was delivered at about $105^{\circ} \mathrm{F}$. A small increase in efficiency corresponding to the change in set point can be seen in the monthly data, but the data points in Figure 27 do not indicate clear correspondence between AHU return water temperatures and efficiencies.

Table 20. NYSERDA Site 8 Average Daily Loads Versus Performance by Month

\begin{tabular}{c|c|c|c|c|c}
\hline \multicolumn{7}{c}{ NYSERDA Site 8 } \\
\hline Month & $\begin{array}{c}\text { Avg. DHW } \\
\text { (Btu) }\end{array}$ & $\begin{array}{c}\text { Avg. AHU } \\
\text { (Btu) }\end{array}$ & $\begin{array}{c}\text { Total Load } \\
\text { (Btu) }\end{array}$ & \% < 105 ${ }^{\mathbf{F}}$ & Efficiency \\
\hline October 2013 & 23,908 & 157,518 & 181,426 & $75.5 \%$ & $94.0 \%$ \\
\hline November 2013 & 19,431 & 208,340 & 227,771 & $85.9 \%$ & $92.7 \%$ \\
\hline December 2013 & 23,745 & 288,278 & 312,023 & $99.7 \%$ & $92.4 \%$ \\
\hline January 2014 & 23,180 & 399,934 & 423,114 & $99.8 \%$ & $93.9 \%$ \\
\hline February 2014 & 17,189 & 357,540 & 374,729 & $99.8 \%$ & $93.3 \%$ \\
March 2014 & 18,183 & 305,745 & 353,534 & $71.6 \%$ & $91.0 \%$ \\
April 2014 & 22,718 & 74,598 & 111,528 & $21.6 \%$ & $89.4 \%$ \\
\hline May 2014 & 16,179 & 12,746 & 40,004 & $16.8 \%$ & $74.4 \%$ \\
\hline
\end{tabular}

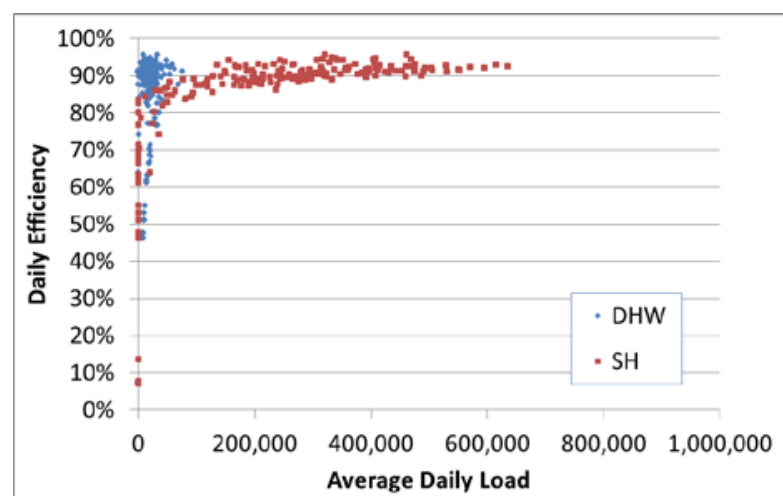

Figure 26. NYSERDA 8 daily efficiencies versus average daily loads

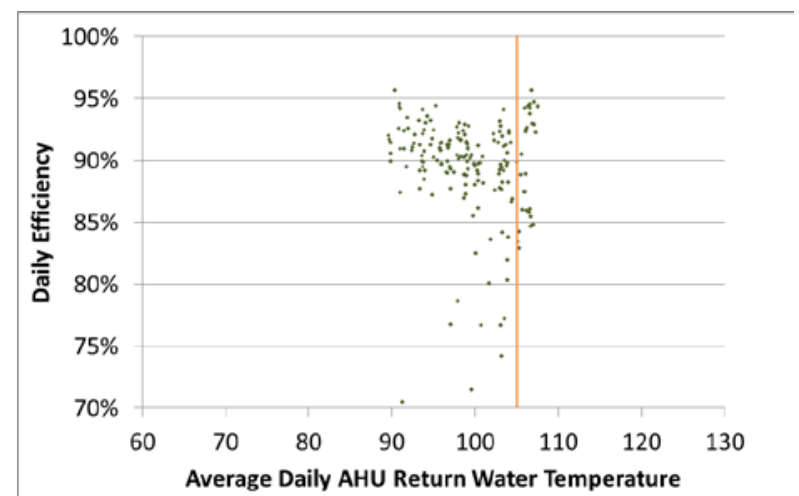

Figure 27. NYSERDA 8 daily efficiencies versus average AHU return water temperatures

\subsubsection{NYSERDA Site 9 Performance Summary}

NYSERDA Site 9 was retrofitted with System F, which consisted of a tankless water heater and a third-party AHU. The AHU for this site was from the same manufacturer as Site 8, and was specifically designed for condensing combi system operation. 
During commissioning of the DAQ system for NYSERDA Site 9, the homeowners commented that they were getting cold and hot water sandwiches.

The water heater set point for this system was maintained at $130^{\circ}-135^{\circ} \mathrm{F}$ during the entire test period. The AHU return water was consistently and significantly colder than $105^{\circ} \mathrm{F}$ (Figure 28) with supply air consistently delivered at $110^{\circ}-115^{\circ} \mathrm{F}$.

Table 21. NYSERDA Site 9 Average Daily Loads Versus Performance by Month

\begin{tabular}{c|c|c|c|c|c}
\hline \multicolumn{7}{|c}{ NYSERDA Site 9 } \\
\hline Month & $\begin{array}{c}\text { Avg. DHW } \\
\text { (Btu) }\end{array}$ & $\begin{array}{c}\text { Avg. AHU } \\
\text { (Btu) }\end{array}$ & $\begin{array}{c}\text { Total Load } \\
\text { (Btu) }\end{array}$ & $\begin{array}{c}\text { \% }<\mathbf{1 0 5} \text { F } \\
\text { Efficiency }\end{array}$ & \\
\hline April 2013 & 83,838 & 102,163 & 186,001 & $99.3 \%$ & $95.2 \%$ \\
\hline May 2013 & 69,239 & 36,970 & 106,209 & $99.1 \%$ & $95.5 \%$ \\
\hline June 2013 & 43,932 & 3,876 & 47,808 & $98.0 \%$ & $94.5 \%$ \\
\hline July 2013 & 49,301 & 2,877 & 52,178 & $99.0 \%$ & $94.5 \%$ \\
\hline August 2013 & 63,362 & 1,716 & 65,078 & $97.3 \%$ & $92.7 \%$ \\
\hline September 2013 & 63,869 & 16,948 & 80,817 & $97.0 \%$ & $91.8 \%$ \\
\hline October 2013 & 65,004 & 58,291 & 123,295 & $98.7 \%$ & $90.9 \%$ \\
\hline November 2013 & 72,265 & 197,173 & 269,438 & $99.1 \%$ & $90.9 \%$ \\
\hline December 2013 & 73,714 & 255,051 & 328,765 & $99.6 \%$ & $91.6 \%$ \\
\hline January 2014 & 90,997 & 337,536 & 428,533 & $99.9 \%$ & $91.4 \%$ \\
\hline February 2014 & 74,839 & 324,957 & 399,796 & $99.8 \%$ & $90.9 \%$ \\
\hline March 2014 & 85,256 & 271,101 & 402,786 & $99.8 \%$ & $90.6 \%$ \\
\hline
\end{tabular}

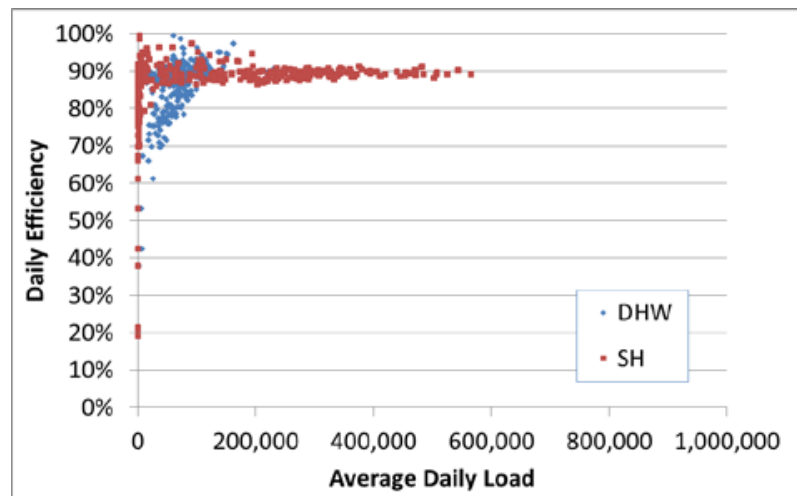

Figure 28. NYSERDA 9 daily efficiencies versus average daily loads

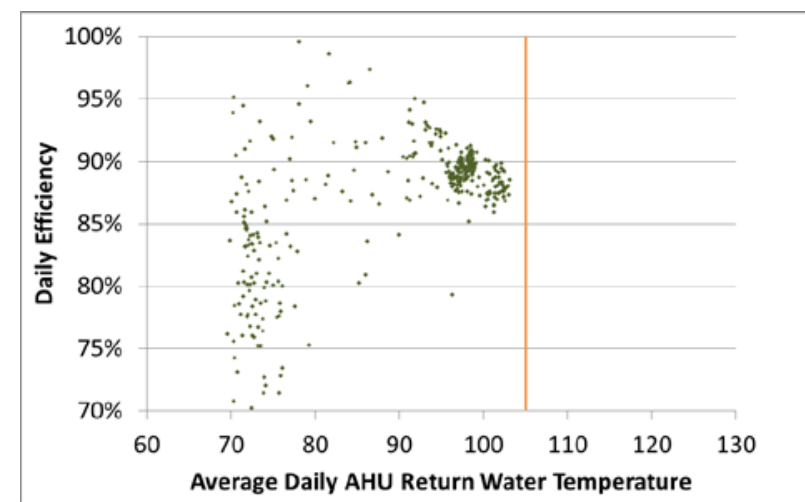

Figure 29. NYSERDA 9 daily efficiencies versus average AHU return water temperatures

\subsubsection{NYSERDA Site 10 Performance Summary}

Like Sites 2 and 3, NYSERDA Site 10 was retrofit with System A, an integrated pre-engineered packaged combi system with a $152 \mathrm{kBtu} / \mathrm{h}$ input tankless water heater. During DAQ commissioning of Site 10, this homeowner also commented that they were getting cold and hot water sandwiches. 
The water heater set point temperature was maintained at $160^{\circ} \mathrm{F}$ for the entire test period. The AHU return water was generally about $110-120^{\circ} \mathrm{F}$ (Figure 31 ) and the supply air was also at $120^{\circ} \mathrm{F}$.

Table 22. NYSERDA Site 10 Average Daily Loads Versus Performance by Month

\begin{tabular}{c|c|c|c|c|c}
\hline \multicolumn{7}{|c}{ NYSERDA Site 10 } \\
\hline Month & $\begin{array}{c}\text { Avg. DHW } \\
\text { (Btu) }\end{array}$ & $\begin{array}{c}\text { Avg. AHU } \\
\text { (Btu) }\end{array}$ & $\begin{array}{c}\text { Total Load } \\
\text { (Btu) }\end{array}$ & \% < 105 $\mathbf{F}$ & Efficiency \\
\hline April 2013 & 24,378 & 120,646 & 145,024 & $36.5 \%$ & $91.4 \%$ \\
\hline May 2013 & 23,220 & 41,281 & 64,501 & $58.3 \%$ & $89.0 \%$ \\
\hline June 2013 & 19,253 & 7,149 & 26,402 & $86.2 \%$ & $83.9 \%$ \\
\hline July 2013 & 14,755 & 6,868 & 21,623 & $81.0 \%$ & $80.4 \%$ \\
\hline August 2013 & 14,521 & 6,782 & 21,303 & $79.8 \%$ & $79.5 \%$ \\
\hline September 2013 & 13,435 & 6,991 & 20,426 & $81.5 \%$ & $78.3 \%$ \\
\hline October 2013 & 18,765 & 54,978 & 73,743 & $49.4 \%$ & $87.4 \%$ \\
\hline November 2013 & 25,439 & 194,307 & 219,746 & $22.0 \%$ & $90.6 \%$ \\
\hline December 2013 & 30,103 & 356,473 & 386,576 & $13.8 \%$ & $90.4 \%$ \\
\hline January 2014 & 28,281 & 422,985 & 451,266 & $10.3 \%$ & $87.3 \%$ \\
\hline February 2014 & 33,105 & 373,663 & 406,768 & $11.1 \%$ & $85.6 \%$ \\
\hline March 2014 & 31,286 & 317,282 & 418,360 & $14.2 \%$ & $85.2 \%$ \\
\hline
\end{tabular}

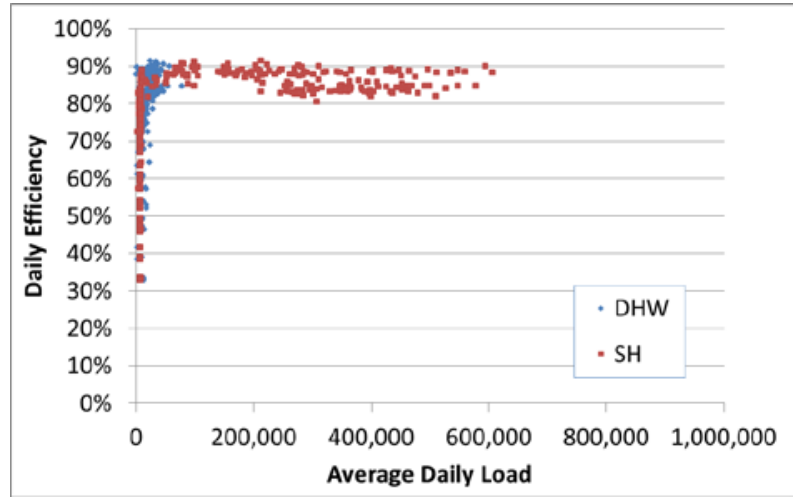

Figure 30. NYSERDA 10 daily efficiencies versus average daily loads

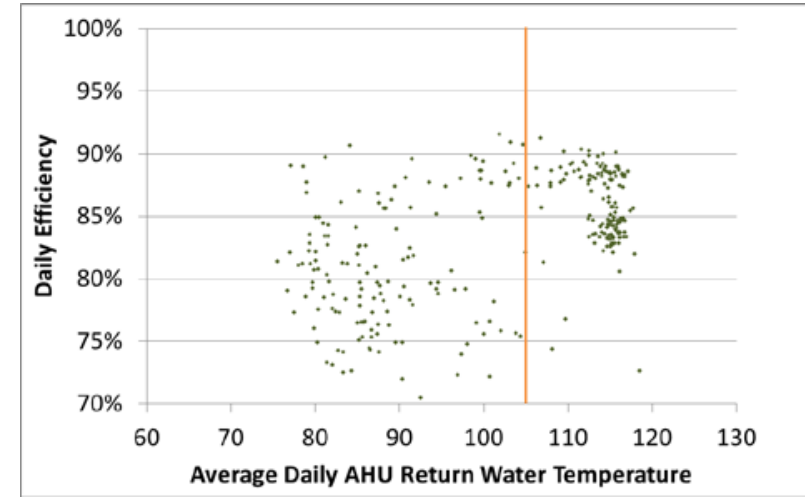

Figure 31. NYSERDA 10 daily efficiencies versus average AHU return water temperatures

\subsection{Efficiency Correlations}

As articulated in Section 3.4 (Measured Efficiencies), there are seasonal correlations that indicate lower efficiencies in summer and shoulder months than in winter months. The data shown in Figure 32 highlight the generally higher monthly efficiencies achieved with pilot sites that were installed with third-party AHUs (NYSERDA Sites 7, 8, and 9) than pilot sites installed with packaged AHUs. The monthly data are shown in descending order for clarity.

Figure 33 shows the correlations between monthly DHW usage and monthly overall efficiencies. The monthly overall efficiencies include DHW and SH. However, it can be seen that there is a general trend toward higher efficiencies when more DHW is used. Unlike return water from the 
AHU that comes back to the water heater quite warm, DHW draws cold water through the water heater from the city main. That cold water helps promote water heater condensing operation, thus higher efficiencies.

Figure 34 shows the correlations between monthly DHW plus SH usage and monthly overall efficiencies. Here again, the monthly overall efficiencies include DHW and SH. In general low DHW and SH use tend to generate low overall efficiencies.

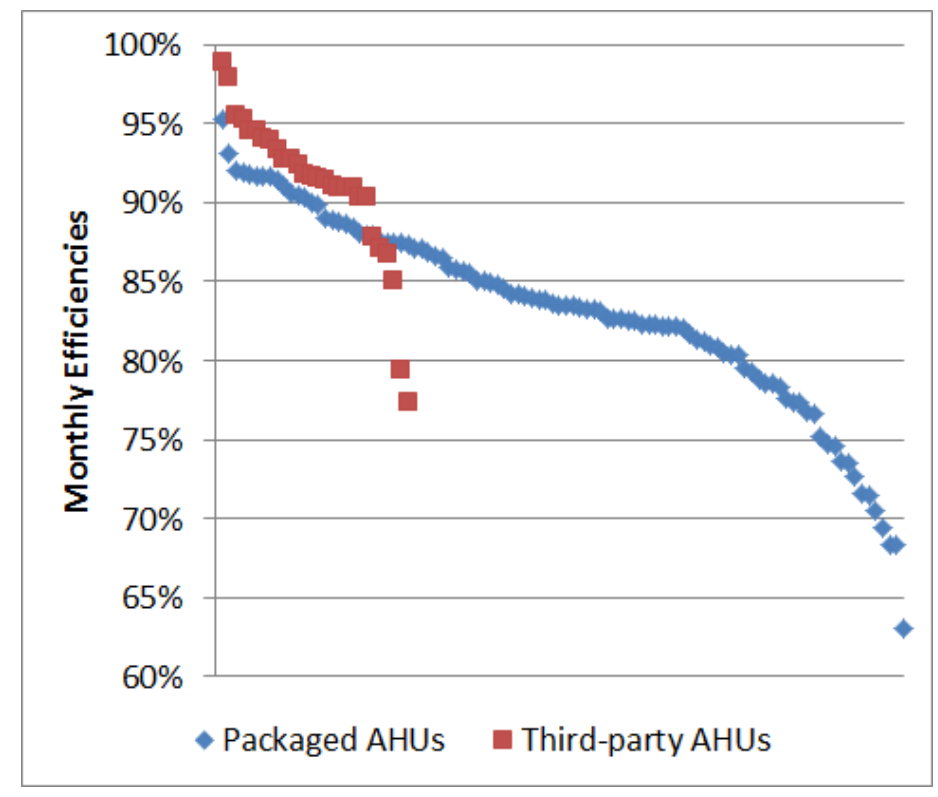

Figure 32. Monthly efficiencies for packaged versus third-party AHUs

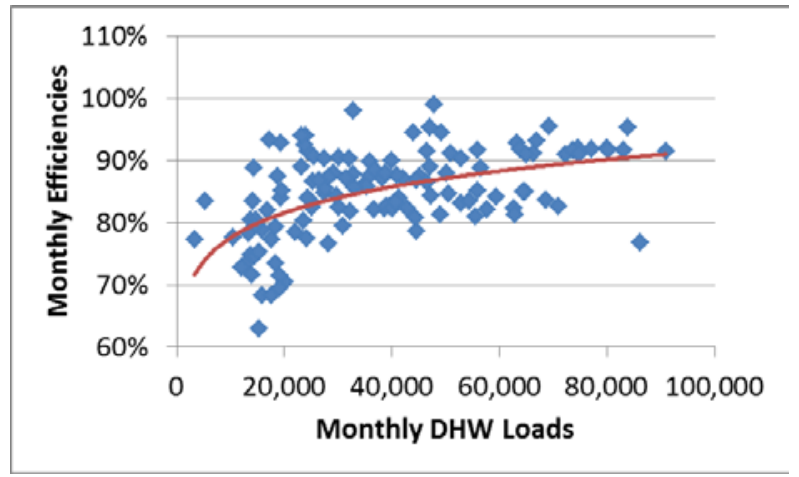

Figure 33. Monthly DHW and efficiency correlations

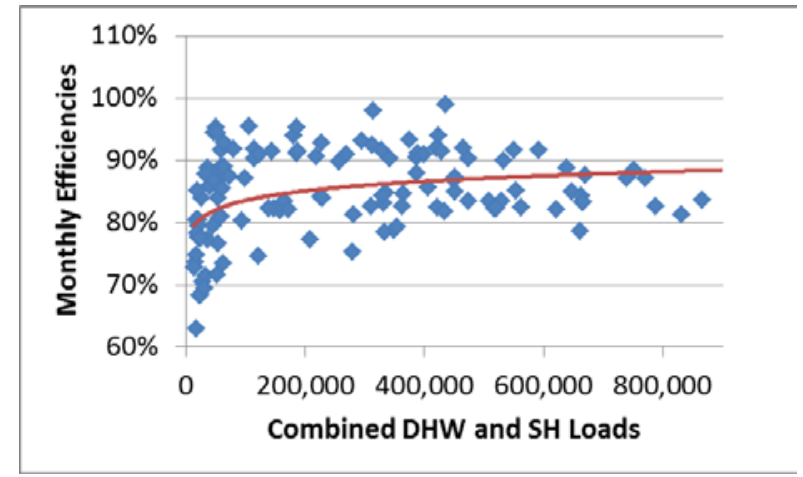

Figure 34. Monthly DHW+SH and efficiency correlations

\subsection{Cost Effectiveness}

\subsubsection{Combi Systems Installed Costs}

Installed cost data for determining cost effectiveness were gathered from the SoCal pilot project rather than the Nicor and NYSERDA projects. Installed cost data were not used from the Nicor work since the installations were done by contractors at their own homes for themselves. Labor 
costs associated with those installations were considered erroneous and not representative of typical trade work through the shop.

Installed cost data were not used from the NYSERDA work, primarily because the contracts were fixed based upon GTI's project budget at costs agreed upon by the HVAC contractors prior to the work. All of the contractors indicated overages, but those overages, including the costs associated with installing the actual combis and the costs associated with installing GTI's instrumentation, were not easily parsed out.

The 15 SoCal sites listed in Table 23 were non-monitored sites that required only combi system installation work. Ten more non-monitored sites plus five monitored sites will be installed before that project is complete. However, only those 15 sites had installed cost data available at the time of this report.

Table 23. Forced-Air Combi Installed Cost Data From SoCal Pilot

\begin{tabular}{|c|c|c|c|c|c|c|c|}
\hline Project & Location & $\begin{array}{c}\text { System } \\
\text { Type }\end{array}$ & \multicolumn{2}{|c|}{ Water Heater } & \multicolumn{2}{|c|}{ Air Handler } & \multirow{2}{*}{$\begin{array}{c}\text { Combi } \\
\text { System }\end{array}$} \\
\hline \multirow{16}{*}{ SoCal } & \multirow{16}{*}{ CA } & \multirow{16}{*}{$\begin{array}{l}\text { Separate } \\
\text { tankless } \\
\text { plus third- } \\
\text { party AHU }\end{array}$} & $\begin{array}{c}\text { Equip } \\
\text { Cost }\end{array}$ & $\begin{array}{c}\text { Install } \\
\text { Cost }\end{array}$ & $\begin{array}{c}\text { Equip } \\
\text { Cost }\end{array}$ & $\begin{array}{c}\text { Install } \\
\text { Cost }\end{array}$ & \\
\hline & & & $\$ 1,750.00$ & $\$ 956.77$ & $\$ 1,460.00$ & $\$ 1,680.01$ & $\$ 5,846.78$ \\
\hline & & & $\$ 1,520.00$ & $\$ 1,205.00$ & $\$ 1,180.00$ & $\$ 1,573.92$ & $\$ 5,478.92$ \\
\hline & & & $\$ 1,250.00$ & $\$ 1,765.41$ & $\$ 1,460.00$ & $\$ 1,680.01$ & $\$ 6,155.42$ \\
\hline & & & $\$ 1,750.00$ & $\$ 1,205.00$ & $\$ 1,180.00$ & $\$ 1,573.92$ & $\$ 5,708.92$ \\
\hline & & & $\$ 1,750.00$ & $\$ 956.77$ & $\$ 1,460.00$ & $\$ 1,680.01$ & $\$ 5,846.78$ \\
\hline & & & $\$ 1,750.00$ & $\$ 956.77$ & $\$ 1,460.00$ & $\$ 1,680.01$ & $\$ 5,846.78$ \\
\hline & & & $\$ 1,060.00$ & $\$ 1,169.80$ & $\$ 1,180.00$ & $\$ 1,573.92$ & $\$ 4,983.72$ \\
\hline & & & $\$ 1,750.00$ & $\$ 956.77$ & $\$ 1,460.00$ & $\$ 1,680.01$ & $\$ 5,846.78$ \\
\hline & & & $\$ 1,750.00$ & $\$ 956.77$ & $\$ 1,460.00$ & $\$ 1,680.01$ & $\$ 5,846.78$ \\
\hline & & & $\$ 1,750.00$ & $\$ 956.77$ & $\$ 1,460.00$ & $\$ 1,680.01$ & $\$ 5,846.78$ \\
\hline & & & $\$ 1,520.00$ & $\$ 1,205.00$ & $\$ 1,460.00$ & $\$ 1,680.01$ & $\$ 5,865.01$ \\
\hline & & & $\$ 1,520.00$ & $\$ 1,205.00$ & $\$ 1,460.00$ & $\$ 1,680.01$ & $\$ 5,865.01$ \\
\hline & & & $\$ 1,750.00$ & $\$ 956.77$ & $\$ 1,460.00$ & $\$ 1,600.86$ & $\$ 5,767.63$ \\
\hline & & & $\$ 1,750.00$ & $\$ 956.77$ & $\$ 1,460.00$ & $\$ 1,680.01$ & $\$ 5,846.78$ \\
\hline & & & $\$ 1,750.00$ & $\$ 1,205.00$ & $\$ 1,430.00$ & $\$ 1,172.53$ & $\$ 5,557.53$ \\
\hline \multicolumn{3}{|c|}{ Average } & $\$ 1,624.67$ & $\$ 1,107.62$ & $\$ 1,402.00$ & $\$ 1,619.68$ & $\$ 5,753.97$ \\
\hline
\end{tabular}

Table 24 shows average installed costs gathered from one of Nicor's EEP implementation contractors for separate high-efficiency furnaces and water heaters. The average costs are based on hundreds of installations and provide a high-efficiency baseline which one can compare to combi systems. However, it is important to note that the storage water heater shown in Table 23 is rated at $0.67 \mathrm{EF}$, significantly less than the $0.95 \mathrm{EF}$ tankless water heaters used for the combis in this study. 
Table 24. Installed Costs for Separate High Efficiency Space and Water Heating Appliances

\begin{tabular}{c|c}
\hline High-Efficiency Equipment & $\begin{array}{c}\text { Average Installed } \\
\text { Costs }\end{array}$ \\
\hline High-Efficiency Furnace - 92\% AFUE & $\$ 3,196$ \\
High-Efficiency Furnace - 95\% AFUE & $\$ 3,591$ \\
Storage Water Heater - EF 0.67 & $\$ 1,111$ \\
\hline
\end{tabular}

\subsubsection{Utility Total Resource Cost}

One method for determining if installed costs and proven benefits of EE methods are sufficient to meet utility gas cost-effectiveness requirements for utility rebates is to apply a Total Resource Cost (TRC) test. The TRC measures the cost and benefits of an efficiency measure as a resource option based on the total cost of the measure to the utility's service territory, including both participant and utility costs. Costs include the cost incurred by the participant to purchase, install and maintain the more efficient equipment and by the utility to market and administer the efficiency program. Any direct installation costs incurred by the utility are also included. Incentives and rebates are not included as they are not a resource cost; instead, they are transfers from the utility to the customer. That is, a rebate increases the utility's cost and decreases the participant's cost by the same amount, with a net effect of zero.

Nicor's TRC method is implemented through a tool that requires estimated input values for the proposed EE measure relative to a predetermined baseline measure. The estimated input values are therm savings, incremental cost, and equipment life. With those input values, the Nicor TRC tool provides a ratio of estimated cost and benefits of the measure versus the total cost to the utility to implement the measure. The EE measure is considered feasible if the resulting ratio is greater than or equal to 1.0. Utility calculations for costs to implement the measure along with calculations for quantifiable benefits are internal to the Nicor tool and unpublished.

Using the Nicor TRC tool, a target incremental cost for combi systems was calculated. Assuming an annual savings of 130 therms as estimated from the Nicor and NYSERDA demonstration data, and assuming a 20-year equipment life, an incremental cost for the measure of $\$ 1,350$ yields a TRC of 1.0 .

The annual savings estimate of 130 therms from the demonstration data can generally be attributed to combi systems that replaced 80\% AFUE forced-air furnaces, and $0.59 \mathrm{EF}$ storage water heaters that represent minimum efficiency standards. Installed cost data were not available for those minimum-efficiency systems.

From the SoCal data, the average installed cost for the combi systems was about $\$ 5,750$. With that cost, the combined installed cost for an $80 \%$ AFUE furnace and a $0.59 \mathrm{EF}$ water heater would have needed to be about $\$ 4,400$ or more in order for the Nicor combi systems to have generated TRCs greater than 1.0. At least one of the Nicor trade allies that participated in the program indicated the combined installed cost for minimum-efficiency systems to be about $\$ 3,500-\$ 3,800$. With those numbers, the installed costs for combi systems need to come down about $15 \%-25 \%$ to pass the utility's TRC tests.

While data were not available for minimum efficiency equipment, data were available for high efficiency systems. Based on those data (Table 23), the average combined installed cost for a 
high efficiency $95 \%$ AFUE furnace along with a $0.67 \mathrm{EF}$ storage water heater is about $\$ 4,700$. An average installed cost for the combi systems of $\$ 5,750$ would yield a $\$ 1,050$ incremental cost.

\subsection{Combi System Equipment Short-falls}

Tankless water heaters were reintroduced to the U.S. market approximately 10 years ago. Current tankless water heater life is claimed at 20 years, yet no study has looked at the long-term reliability of these systems. Given the diversity of water quality and water use throughout the United States such a study on in-situ units is both possible and warranted, particularly for units that operate in the condensing mode. Combo systems require the tankless water heater to supply the AHU with sufficiently hot water to achieve supply air temperatures of $105^{\circ} \mathrm{F}$ or higher, which generally requires the tankless unit to produce hot water at $120^{\circ}-160^{\circ} \mathrm{F}$. Heating water to this temperature can result in the development of mineral scale and galvanic corrosion, which can require an annual cleaning/maintenance routine to ensure that system performance remains unaffected by buildup. The inlet strainer in a tankless water heater is designed to protect the modulating water valve and flow meter. Potential clogging of the inlet strainer and accumulation of calcium or lime scale in the heat exchanger and piping can be a concern. Additional prestraining of the water just before it enters the tankless unit is an important step for keeping maintenance intervals as reasonable as possible, generally every year (Rudd 2012). Some manufacturers have built-in controls and indicators that designate when the unit is beginning to lime up and should be flushed.

Temperature set point of the water heater, and more specifically the temperature of water returning to the water heater from the AHU, has an effect on system efficiency. While a set point of $140^{\circ} \mathrm{F}$ or more may be needed to provide enough heat for $\mathrm{SH}$, it may be too high to allow for cool enough return water to induce condensing operation in the water heater. One way to increase condensing operation is to improve the AHU design. The higher the airside temperature difference in the AHU, the lower the return water temperature is to the AHU; thus, the lower the flue gas temperature. That situation increases the likelihood of condensing operation. However, it is difficult to predict conditions where one tankless water heater will condense and another will not. There are other factors that will determine if and how much condensing operation will occur (Kosar et al. 2012), such as design of the heat exchanger (material, surface area, fin spacing, number of tube passes, etc.) as well as flue gas parameters (excess aeration or dilution, firing rate/burner staging, and pre/post-purge characteristics). For example, by minimizing the excess air in the water heater combustion process, a higher flue gas dew point is created. Thus, the system may still condense at AHU return water temperatures greater than $105^{\circ} \mathrm{F}$ due to the higher flue gas temperature required for condensing.

In some cases, storage tanks may be used as primary water heaters or to supplement tankless water heaters. In such cases, check valves are used to prevent thermo-siphoning over the air handler heating coil when heat is not called for. It is important that there are check valves installed and operating properly for all combi system installations with storage capacity. In a previous study (Scott and Kalensky 2006), GTI found that a defective check valve could decrease combi system efficiency by as much as $25 \%$. Without monitoring equipment, there is no way to ensure that check valves are operating properly.

Like other SH systems including boilers and furnaces, low SH load scenarios such as warmclimate applications and heating during shoulder months in cold climates creates efficiency 
challenges. Cycling losses (and any standby losses) become a higher fraction of the total thermal load and degrade overall efficiencies. Yet to satisfy buyer's desires to have unlimited hot water from their tankless water heater, contractors often make sizing decisions based on DHW needs. For example, if a homeowner wanted to be assured of continuous hot water for multiple shower heads, the contractor would select the highest capacity tankless water heater. However, during low SH load scenarios, the water heater performance can be compromised and its efficiency degraded.

\subsection{Combi System Installation Barriers}

Contractor labor tends to be a multiplier of system and material costs. As such, the presumed benefit of installing a single-appliance combi system does not exist yet. Based on installed cost data to date, combi system installations take longer, and require higher material costs than traditional separate appliances, and have greater installation and setup complexity.

Although combis are based on water heater technology, some plumbers are reluctant to install them because they have limited HVAC background. On the other hand, some HVAC contractors (especially small shops) are reluctant to install combis because they do not have licensed plumbers. Some contractors are reluctant to install combis simply because they are unfamiliar with the technology and believe local code prevents them from doing so, as was initially the case in Nicor's territory.

GTI found that even after providing training for the installing contractors under the pilot programs, the combi systems were often installed without full regard to the guidelines that were provided. In-field tweaking by technicians intimately familiar with the systems and what makes them perform at high efficiencies would still be needed during early market development.

A typical hydronic AHU for combo systems includes a hot water coil and pump along with a blower and controls for thermostat calls. It is a hydronic-coil-only heating system, and most of the hydronic furnaces on the market have this configuration. For retrofits, the direct expansion coil for cooling is often a separate device unmatched with the hydronic furnace, thus no seasonal energy efficiency ratio/energy efficiency ratio rating. That presents potential system installation and performance problems as well as quality and responsibility concerns by HVAC contractors.

Contractor costs can likely be reduced and in-field performance improved with advanced water heater and AHU products that are coordinated, have simpler installation requirements, and have sizing and installation guides specific to combi applications.

\subsection{Market Transformation}

Pilot data are proving that energy savings from combis are substantial $(15 \%+)$. However, incremental costs are currently marginal in terms of generating positive utility TRCs. Installed costs for combi systems need to come down by about $15 \%-25 \%$ to meet utility TRCs. Greater sales volumes of tankless water heaters and hydronic AHUs will drive equipment costs down. One AHU manufacturer associated with the SoCal pilot work has indicated potential near-term cost reductions on the order of $12 \%$ as a result of higher demand and less expensive components. Such reductions could drop the total installed cost of combis by more than $3 \%$. More significant reductions in installed costs could come from greater contractor familiarity with combi systems. 
Given that the Nicor TRC tests for combis are marginal, educating contractors and generating greater contractor familiarity with combi systems would be imperative to market transformation.

Nicor no longer offers residential, high efficiency, stand-alone water heater incentives because TRCs are falling well below 1.0. The same dilemma with stand-alone water heaters is being encountered by other utilities. The utilities are struggling with appropriate ways to raise water heating efficiencies cost effectively. Combi systems can raise water heating efficiencies along with SH efficiencies. If installed costs come down and market economics improve as noted above, utilities may have the opportunity to package combi system incentives that would allow them to raise water and $\mathrm{SH}$ efficiencies at an attractive TRC.

\subsection{Programmatic Efficiency Measurement and Verification}

Field demonstration projects are conducted to, among other things, gather data on as-installed performances. While those data are extremely valuable, as the Nicor and NYSERDA data show, it is difficult to make direct system comparisons because of the many host site variables such as as-installed scenarios that demand various degrees of cycling, standby losses, and other loadsensitive variables.

Applying a methodology of testing that subjects heating systems to characteristically repeatable and controllable loads provides the opportunity to analyze and compare performances of those systems under actual conditions.

GTI has developed a laboratory methodology for subjecting SH and water heating systems to simulated as-installed loads in order to estimate in-field performance under various measured conditions. The methodology was first developed for BA work (Kingston and Scott 2013) and then implemented on utility-funded combi System projects. The methodology involves the development of Energy Plus residential building models; use of the National Renewable Energy Laboratory's DHW Event Scheduler; and simulated control of the following:

- SH loads and thermostat calls

- DHW draws and flows

- Outdoor air temperatures

- Municipal water inlet temperatures.

Figure 35 shows the conceptual approach to each of the four control variables above. 


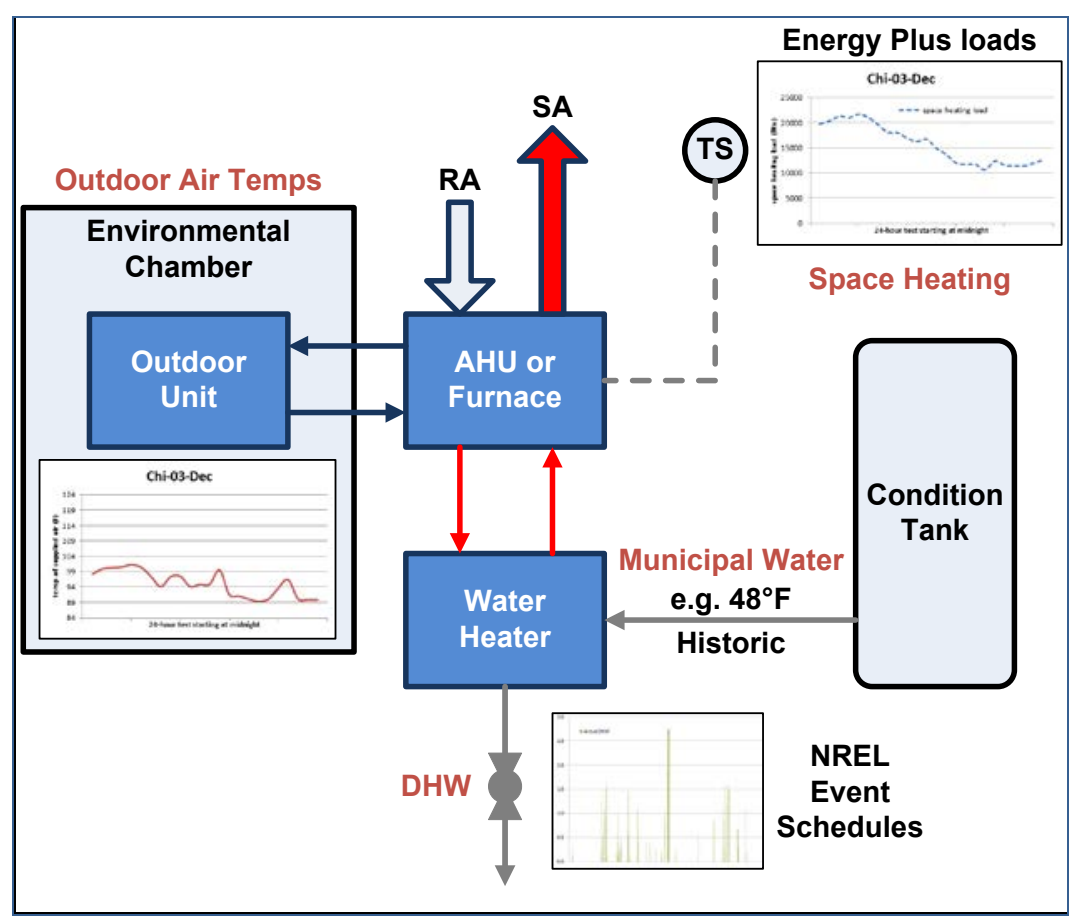

Figure 35. Laboratory test methodology for programmatic M\&V

$\mathrm{SH}$ is accomplished through algorithms that force thermostat calls to the AHU or furnace. Five or six calls are forced per hour and last as long as required to meet hourly loads calculated in an EnergyPlus 8.1.0 simulation model.

DHW draws are achieved through algorithms that control a modulating valve. Water draw event schedules are developed using the DHW Event Scheduler. The simulation tool allows users to generate DHW profiles that take into account complex occupant behaviors such as number of bedrooms, vacation periods, weekday/weekend effects, geographic locations, seasonality, and individual water fixture uses including sink, shower, bath, clothes washer, and dishwasher.

For systems with outdoor units such as heat pumps or for systems with outdoor reset functions such as combi boilers, an outdoor environment must be simulated. This is done with an environmental chamber and algorithms to modulate the daily outdoor air temperature profiles corresponding to the building SH loads.

Municipal water from the buried mains can range from less than $45^{\circ} \mathrm{F}$ to more than $80^{\circ} \mathrm{F}$ depending on location and time of year. Water is controlled to constant temperatures using a water conditioning tank.

These four control strategies applied concurrently allow repeatable tests to be conducted on multiple systems. It provides an opportunity to investigate the relative performances of systems as might be seen in field applications, but under controlled conditions. 


\section{Conclusions}

The following findings were drawn from the results of 13 monitored forced-air tankless water heater combi system demonstrations and pilots in the cold climates of the Chicago area and New York State. The following are answers to the research questions posed in Chapter 2:

What are expected energy savings for single-family detached homes?

- Natural gas savings averaged across the 13 sites is estimated to be in the range of 5-13\%. Gas savings was estimated using monitored post-retrofit performance and pre-retrofit nameplate efficiency values.

What is SH efficiency for installed systems?

- Cumulative combi system efficiencies were from near $80 \%$ to about $93 \%$. Of the 13 monitored systems, there were 10 combi systems that were sold as integrated water heater and AHU packages. Nine of the integrated combi systems had cumulative system efficiencies near $80 \%$ to about $87 \%$ and one integrated combi system had a cumulative system efficiency of about $90 \%$. The remaining three combi systems were pieced together with separate water heaters and AHUs that were specifically designed for condensing combi system operation. Those three combi systems had cumulative system efficiencies of about $92 \%-93 \%$.

How can efficiencies be optimized through equipment selection, installation strategies or site selection?

- Most currently available hydronic AHUs were not designed for combi systems with a condensing heating plant (Schoenbauer et al. 2012). The combis that were sold as integrated water heater and AHU packages for this project were not designed to maximize temperature drops across the hydronic coils while maintaining sufficient supply air flows and temperatures. Therefore, water temperatures returning from the AHU to the water heater were not low enough to induce condensing water heater operation at many of the sites. One manufacturer of integrated combis that participated in the NYSERDA project has since discontinued sales of AHUs; instead aligning its product with a third-party AHU manufacturer. Another manufacturer of integrated combis has committed to a next-generation combi package that addresses shortfalls such as inconsistent condensing operation. Some third-party AHU manufacturers, including those participating in the NYSERDA project, have focused attention on combi system performance. Their AHUs are designed with water-to-air heat exchangers that transfer heat from the hot water to the room air more effectively, thereby maximizing coiltemperature drops while maintaining comfortable supply air. Forced-air combi system performance would benefit from the use of such "advanced" AHU designs.

- Like other SH systems including boilers and furnaces, combi system efficiencies are negatively impacted by low SH load scenarios such as warm-climate applications and heating during shoulder months in cold climates. Cycling losses (and any standby losses) become a high fraction of the total thermal load and degrade overall efficiencies. To 
satisfy market demand for unlimited DHW, contractors may choose the highest capacity tankless water heater available. However, despite manufacturer-claimed turndowns of up to 10:1 (in terms of burner capacity), results from this study indicate compromised performance during some low SH load scenarios. Combi system performance would benefit from right-sized systems and control strategies that account for SH loads relative to burner capacities.
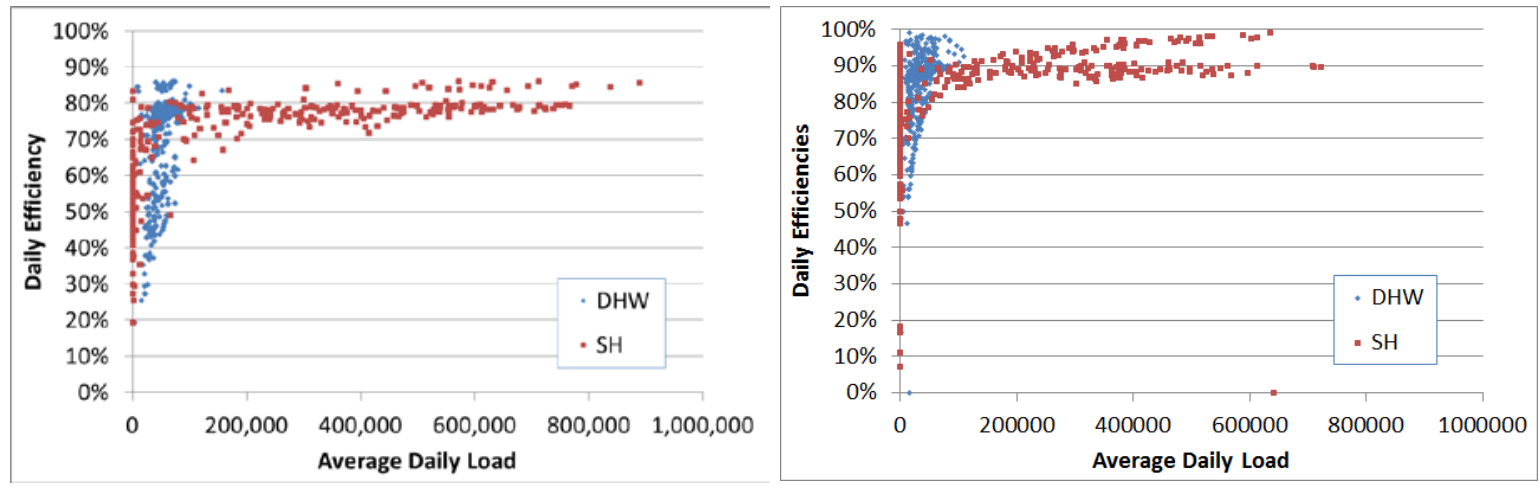

- The NorthernSTAR DOE BA team set the maximum threshold for achieving condensing operation in combi systems at $105^{\circ} \mathrm{F}$ AHU return water (Schoenbauer et al. 2012). Data from the monitored combi systems indicate strong correlations between reduced AHU return water and increased efficiencies. In several cases, higher efficiencies (near $90 \%$ and above) were seen with return water temperatures less than $105^{\circ} \mathrm{F}$ than efficiencies seen with return water temperatures greater than $105^{\circ} \mathrm{F}$. However, there were exceptions where $90 \%+$ efficiencies were achieved with return water greater than $105^{\circ}-125^{\circ} \mathrm{F}$. Conversely, some data indicate efficiencies in the low eighties with AHU return water consistently less than $105^{\circ} \mathrm{F}$. More research is needed to better understand the factors that affect condensing operation, such as heat exchanger and combustion design and control strategies.

Do systems fall short of meeting space or water heating load; was occupant comfort or convenience impacted?

- Combi systems installed in all of the monitored homes for the Nicor and NYSERDA studies met SH loads. Pilot sites were from about 1,500 $\mathrm{ft}^{2}$ to larger than $3,000 \mathrm{ft}^{2}$ and in at least one case, the combi system was used in a zoned configuration with another heating system (no notable impact on efficiencies). Estimated SH load calculations for all of the pilot sites were less than $65 \mathrm{kBtu} / \mathrm{h}$. However, in some cases the water heater set point had to be increased up to $160^{\circ} \mathrm{F}$ to deliver comfortable supply air.

- Combi systems installed in all of the monitored homes for this study met the DHW loads. However, some homeowners reported cold water slugs between hot water flows. This is known as the cold water sandwich effect and is a fairly common complaint with tankless water heater operation. The cold water sandwich effect is not attributed to added $\mathrm{SH}$ loads. 
Are there any significant barriers to installing combined systems, house or site attributes that should be avoided?

- Demonstration and pilot projects are often conducted in existing homes to provide baselines for performance and savings comparisons. However, combination systems may make the most sense in new construction since proper design of the total system is possible, including properly sized and insulated plumbing to avoid extended delay time in delivering water, and properly sized and sealed air ducts (Rudd 2012). In retrofit cases, the existing gas service line (either the outside utility line or in building) may not have adequate capacity to serve the high demand of a tankless water heater or high capacity storage type water heater. In addition, retrofit venting may be more difficult, and old scaled pipes may worsen water flow or inlet filter clogging problems (Rudd 2012).

- Field tests for this study exposed installation deficiencies due to contractor unfamiliarity with the products and the complexity of field engineering and system tweaking to achieve high efficiencies. Widespread contractor education must be a key component to market expansion of combi systems.

Does the detailed analysis of gas use data from instrumented demonstrations compare similarly to the gas billing data analysis approach (which would likely be used to verify energy savings under a full-scale program)?

- Demonstration and pilot data are extremely valuable for providing as-installed performance data, user satisfaction, and installing-contractor behavior. However, as the data from this project show, it is difficult to make direct system comparisons because of the many pilot site variables. More research is needed to determine how well heating systems such as traditional furnace/water heater, combis, and heat pumps compare in similar as-installed scenarios, but under controlled conditions.

Are the expected installed costs and proven benefits sufficient to meet utility gas costeffectiveness requirements for utility rebates?

- Average installed cost for forced-air combi systems was determined to be about \$5,750. That cost is about $15 \%-25 \%$ too high for generating acceptable utility total resource cost of 1.0 or higher; and it is another reason for educating contractors and generating greater contractor familiarity with combis in order to drive installation costs down and initiate market transformation.

What is appropriate incentive level for the system and how should it be delivered to best drive market adoption (e.g., to contractor, to end user)?

- One way to accomplish extensive training would be at the program level through utility EEP implementation contractors. The implementation contractors are responsible for executing individual EE measures and as part of their work they link end users to installing contractors. Bulk training via combi system workshops could be accommodated as part of EEP measure implementation.

- Nicor and other gas utilities are looking for ways to improve the benefits of highefficiency water heating measures in their EEPs. By raising water heating and SH 
efficiencies with one EE measure, the benefits could be improved enough to outweigh the cost to the utility to implement a combi system measure.

\subsection{Recommendations}

Months of in-field combi systems performance data from multiple pilot sites and for various systems have shown that combi systems can perform at very high efficiencies. However, the data also indicate that long-term performance can be negatively affected by high temperature set points (or low differential temperatures across the AHU water coils), low loads, and cycling losses among other in-field variables. When conducting heating system performance comparisons between systems it is helpful to understand how the systems perform across a wide range of loads and at different operating conditions. Applying a consistent methodology for testing field-assembled combi systems against as-installed loads in the controlled environment of a laboratory allows stakeholders such as manufacturers, utilities, and researchers to determine how these systems perform under these conditions.

GTI recommends further research with an objective to provide comparative data for conventional and alternative $\mathrm{SH}$ and water heating systems. The data can be used by manufacturers, installing contractors, and utilities to better understand relative performances in terms of heating system efficiencies. Specific goals for such research would include:

- Test heating systems against as-installed space and water heating loads that are typical to residential applications.

- Conduct the tests under controlled conditions in a laboratory setting where as-installed conditions can be consistently replicated.

Alternatively, GTI recommends in-field testing to be conducted in a controlled manner such as a test house. 


\section{References}

Kingston, T.; Scott, S. (2013): "Laboratory Evaluation of Gas-Fired Tankless and Storage Water Heater Approaches to Combination Water and Space Heating" Gas Technology Institute, Des Plaines, IL www.nrel.gov/docs/fy13osti/57075.pdf.

Kosar, D.; Glanville, P.; Vadnal, H. (2012): "Facilitating the Market Transformation to Higher Efficiency Gas-Fired Water Heating" Gas Technology Institute, Des Plaines, IL www.energy.ca.gov/2013publications/CEC-500-2013-060/CEC-500-2013-060.pdf.

Rudd, A. (2012). "Measure Guideline: Combination Forced-Air Space and Tankless Domestic Hot Water Heating Systems" Building Science Corporation, Somerville, MA www.buildingscience.com/documents/bareports/ba-1206-measure-guideline-combinationforced-air-space-tankless-domestic-hot-water-heating-systems.

Schoenbauer, B. (2011). Center for Energy and Environment, Minneapolis, MN. Presentation at U.S.DOE Building America Expert Meeting.

www.buildingscienceconsulting.com/services/building-america-expert-meetings.aspx.

Schoenbauer, B.; Bohac, D.; Huelman, P.; Olson, R.; Hewett M. (2012): "Retrofitting Combined Space and Water Heating Systems: Laboratory Tests" NorthernSTAR Building America Partnership, Saint Paul, MN www.mncee.org/getattachment/798d9c6d-2aea-4066a6e1-735eedd6bb0f/.

Scott, S.; Kalensky, D. (2012): “GTI Combo System Field Test Final Report” Gas Technology Institute, Des Plaines, IL www.gastechnology.org/reports software/Pages/default.aspx. 


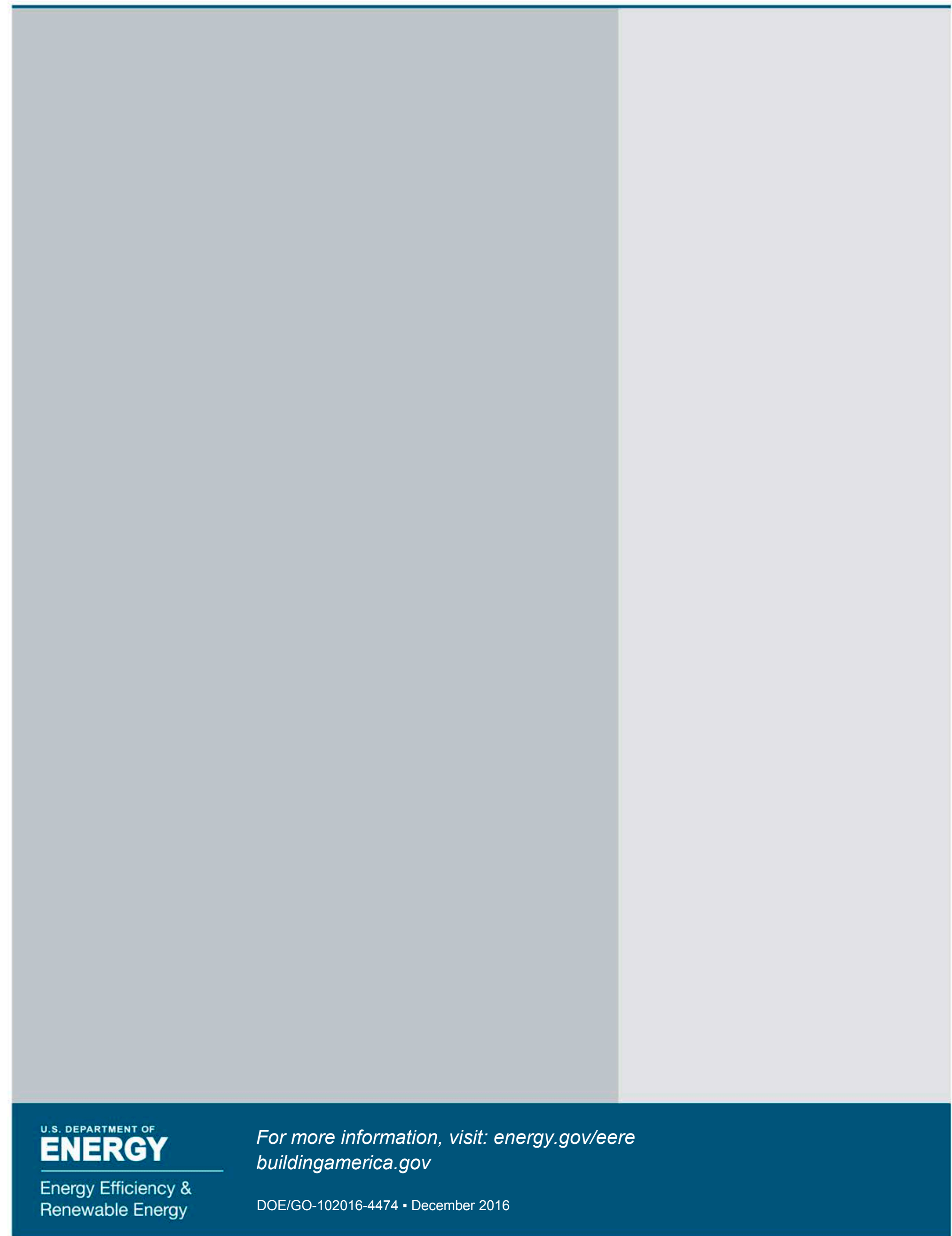

